
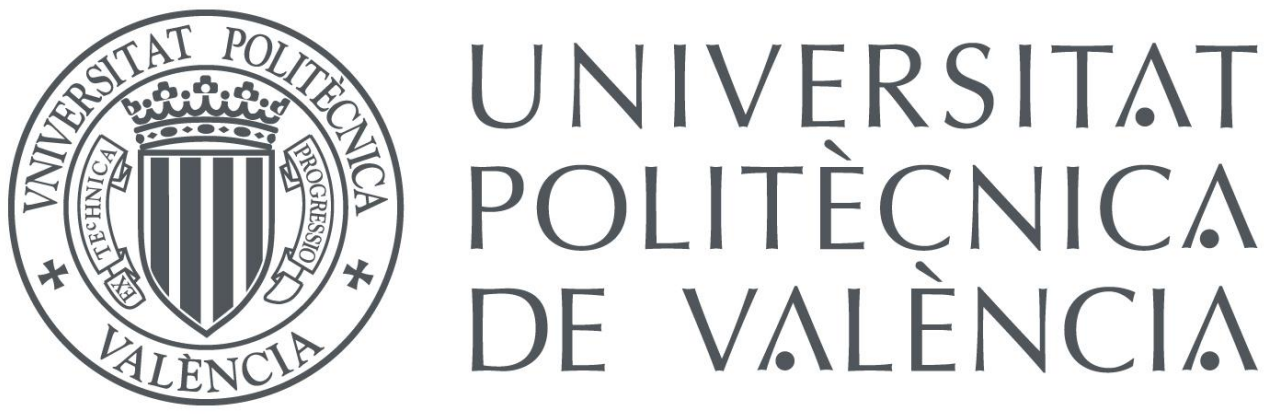

Universitat Politècnica de València

Doctoral Thesis

Doctoral Programme in Biotechnology

\title{
3D CULTURE OF MULTIPLE MYELOMA CELL LINE USING MICROGEL ENVIRONMENTS
}

Juan Carlos Marín Payá

November, 2020

Supervised by:

Dr. Amparo Sempere Talens

Prof. José Luis Gómez Ribelles 


\section{Acknowledgments}

Y al final aquí estamos, después de un largo viaje donde a veces es difícil vislumbrar tierra firme yendo por recovecos que te hacen llegar de nuevo al punto de partida, creo que, por fin he pisado tierra. Digo creo, porque todavía es difícil de creer, después de tantos laberintos y mapas difíciles de interpretar, al final se ha conseguido. Una tarea difícil, que sin la ayuda de mis compañeros no podría haber sido posible. De entre todos ellos destacan mis compañeros del CBIT (sitio de trabajo, reunión y amistades). En especial a mi querida Sandra, compañera y amiga durante los primeros años de tesis que entre tanto canto y rodeos por La Fe forjamos una gran amistad. A mitad del camino apareció María, una nueva pre-Doc que entraba con ganas y con una gran sonrisa (Ja... que ingenua) que entre los ratos de laboratorio, reuniones y comidas otra nueva amistad había surgido. Justo al final estuvo Luis, un nuevo compañero y amigo apareció de la nada haciendo malabares con la impresora y entre alginato y microesferas todavía me debe una francesinha (no se me olvida). Tampoco quiero olvidarme del resto de compañeros y jefes: Gloria, Silvia, Laura T. y R., Rubén, Hayk, Guillermo, Ximo, Rosa $\mathrm{y}$ un largo etc...que han podido contribuir a mi desarrollo tanto profesional como personal. Nunca habría imaginado llegar a cultivos sin que el Señor Don Hayk (ahora Doctor) no estuviera lanzando maldiciones a diestro y siniestro como tampoco olvidaré su gran ayuda como la de Ximo y Guillermo a resolver todas las dudas que me surgían (que no eran pocas). Qué decir del "zulo" ese sitio acurrucado del CBIT donde se aglutinaban todos los alumnos y que tantos buenos momentos nos ha dado. Aunque si hay algo que siempre recordaré con mucho cariño, es el haber podido co-dirigir trabajos Fin de Máster y Grado por la responsabilidad que supone estar pendiente del alumno para que su estancia sea la más agradable posible (dentro de las circunstancias) y que a su vez contribuya a su mejora profesional. Como olvidar los momentos con Brent y Nikolina polimerizando o el tiempo pasado con Sam tanto en el laboratorio como fuera de él y como no, a mi alumna favorita Blanca ("Diosito que te hemos hecho") en la que gran parte de este éxito se consiguió gracias a su labor haciendo bolitas de alginato.

En cuanto a la Fe... que puedo decir del sitio que me acogió hace ya muchos años para realizar el Trabajo Fin de Grado y al que volvía para realizar la Tesis. Nunca olvidaré 
esos días oyendo de fondo las voces de Amparo, Inma, Pilar y Concha comentando y siguiendo la lotería de Navidad. Los ratos delante del ordenador con Lourdes explicándonos la citometría de flujo (que de gran ayuda ha sido para la Tesis) quedaran para el recuerdo.

Tampoco puede faltar el pilar fundamental de mi vida que lo constituye mi familia desde primos, tíos y abuelos, hasta mi Padre, Madre y hermana que con su gran ayuda y apoyo diario no habría sido posible llegar hasta este momento. También está mi "otra" familia que con el apoyo incondicional de Teresa junto a sus hermanos y padres me han acompañado en este largo camino haciendo posible tener las fuerzas suficientes para terminar este camino. Cabe destacar también la especial ayuda recibida por parte de Richard, al cual espero conocer en persona algún día, en la finalización de esta Tesis.

Por último, quiero agradecer a mis directores de tesis, tanto a José Luis como Amparo por darme la oportunidad de poder vagar por este mundo de microgeles y entornos 3D que tantos quebraderos de cabeza nos han dado y que a su vez ha permitido abrir, o eso creo, un nuevo enfoque sobre el que seguir estudiando en un futuro.

La presente tesis doctoral no se podría haber realizado sin la financiación del proyecto PROMETEO/2016/063, trabajo que también estuvo parcialmente financiado con fondos FEDER (CIBERONC (CB16/12/00284)). La iniciativa CIBER-BBN está financiada por el proyecto VI National R\&D\&I Plan 2008-2011, Iniciativa Ingenio 2010, Consolider Program. Las acciones CIBER están financiadas por el Instituto de Salud Carlos III con ayuda del Fondo Europeo de Desarrollo Regional.

Y como dijo mi alumna favorita, sigamos fluyendo, sigamos...porque a pesar de ser un camino difícil, es un camino que merece la pena, lo merece porque cada paso que damos abre las puertas para descubrir una maraña de conocimiento que poco a poco va adquiriendo sentido y como no... que mejor manera de vivir la vida que hacer lo que no está escrito, pudiendo describir e interpretar lo que observamos, generando nuevos mapas que puedan servir de guía para otros, con el fin de encontrar nuevos tesoros y entrar en un ciclo sin fin de conocimiento. 


\section{INDEX}

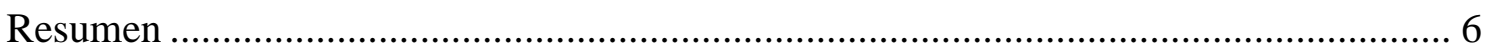

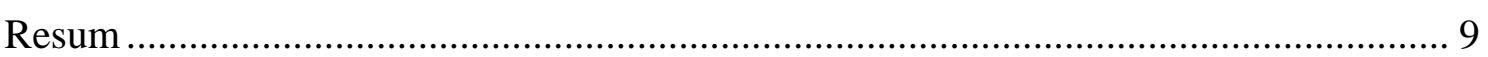

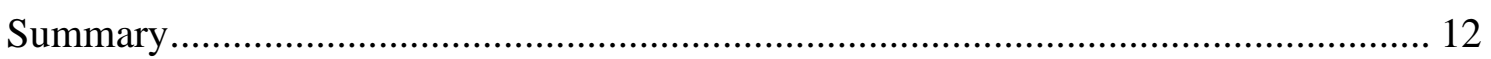

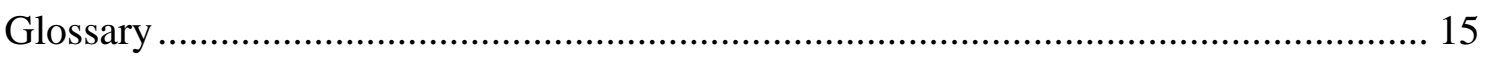

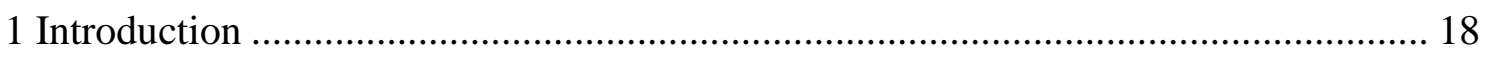

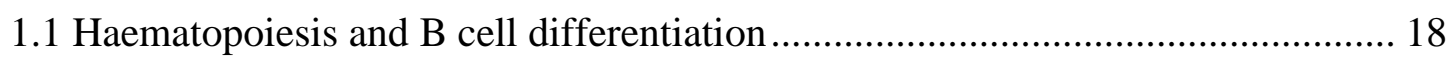

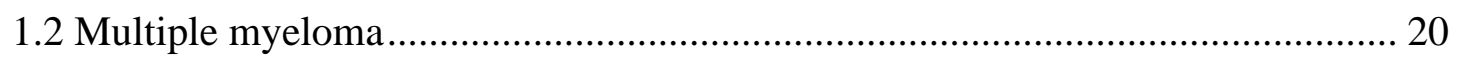

1.3 Influence of the bone marrow microenvironment on the maintenance and survival

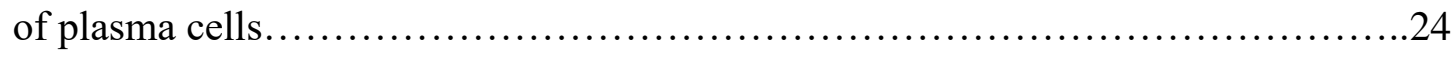

1.3.1 Influence of the bone marrow microenvironment on the maintenance and survival of normal plasma cells........................................... 25

1.3.2 Influence of the bone marrow microenvironment on the maintenance and survival of monoclonal plasma cells.......................................... 26

1.4 Interaction between monoclonal plasma cells and extracellular matrix components and their effect on cell adhesion-mediated drug resistance......................... 27

$1.52 \mathrm{D}$ vs. 3D culture systems ............................................................................. 30

1.6 3D multiple myeloma culture platforms ........................................................... 32

2 Hypothesis and Objectives ................................................................................ 33

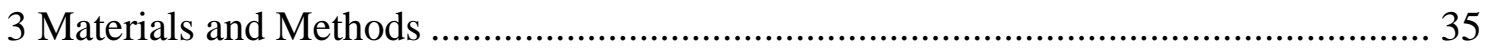

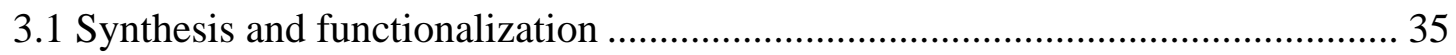

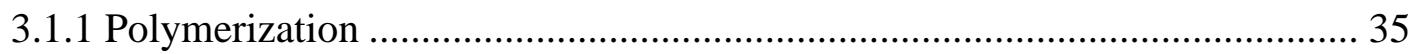

3.1.2 Acrylic microspheres synthesis by emulsion ................................................ 36

3.1.3 Alginate microspheres synthesis by microfluidic device ................................ 37

3.1.4 Biomolecule grafting using carbodiimide chemistry ..................................... 38

3.1.5 Biomolecule coating by physical adsorption …………………………….... 39

3.1.6 Coatings through a layer-by-layer technique …………………...................... 39

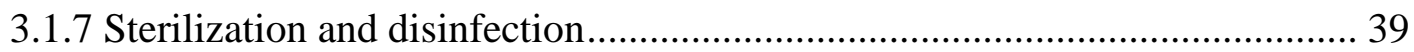

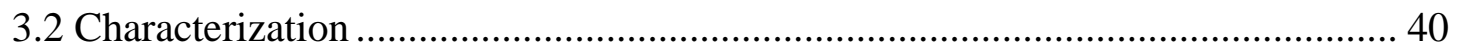

3.2.1 Physical characterization of the microspheres .............................................. 40

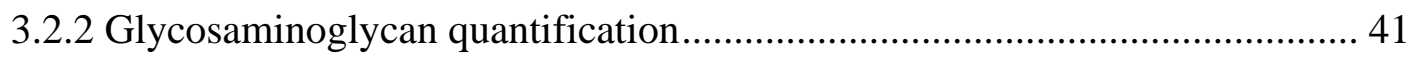

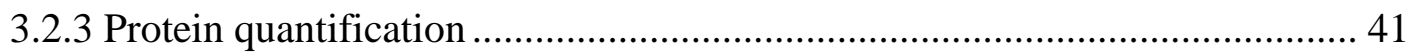

3.2.4 Spectroscopy detection....................................................................... 42

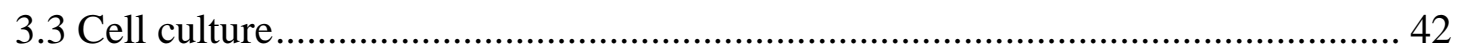


3.3.1 Cell culture growth protocol

3.3.2 3D culture on acrylate microspheres microgels ......................................... 42

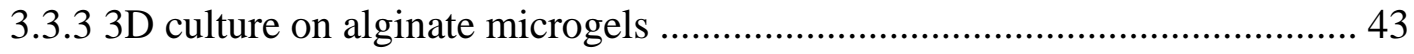

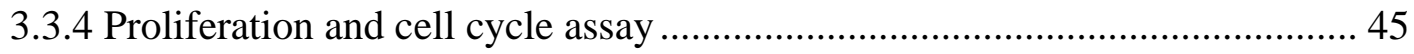

3.3.5 Viability assay and drug resistance analysis .............................................. 46

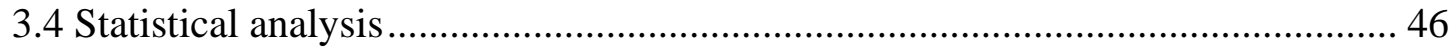

4 Results and Discussion.................................................... 47

4.1 Synthesis and functionalization of different microgels.......................47

4.1.1 Development and functionalization of microgels based on acrylic microspheres.........................................................49

4.1.2 Development and functionalization of microgels based on alginate microspheres...................................................57

4.1.3 Concluding remarks related to the development and functionalization of different microgels.....................................................66

4.2 Evaluation of the cellular behaviour in a 3D culture environment based on functionalized microgel with extracellular matrix components...................67

4.2.1 Influence of volume fraction of acrylic microspheres on cell proliferation...70

4.2.2 Influence of volume fraction of alginate microspheres on cell proliferation in an environment with the presence of hyaluronic acid and/or collagen type I.......72

4.2.3 Influence of cell adhesion to fibronectin on cell cycle....................77

4.2.4 Influence of integrin $\beta_{1}$ on cell adhesion to fibronectin and cell growth.....78

4.2.5 Cell behaviour in an environment with the presence of heparin or heparan

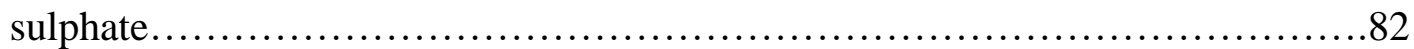

4.2.6 Concluding remarks related to cell behaviour in a 3D culture platform based on microgel................................................................ 85

4.3 Drug resistance induced by the extracellular matrix components presented in the

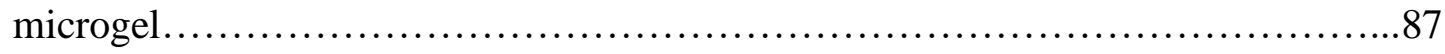

4.3.1 Cell adhesion to hyaluronic acid and collagen type I and its effect on drug resistance to dexamethasone and bortezomib ................................................ 88

4.3.2 Cell adhesion to fibronectin and its effect on drug resistance to dexamethasone and their cell adhesion reversion by the effect of bortezomib 91

4.3.3 Concluding remarks related to drug resistance induced by cell adhesion to extracellular matrix components ................................................................. 93

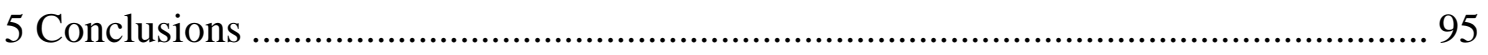

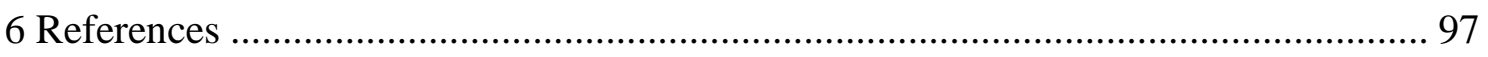




\section{Resumen}

El mieloma múltiple es una neoplasia hematológica caracterizada por una expansión descontrolada de células plasmáticas monoclonales (mPCs) en medula ósea que producen, en la mayoría de los casos, un componente monoclonal secretado en el suero y/o en orina. En la actualidad, se sigue considerando una enfermedad incurable con la constante aparición de recaídas en los pacientes. Una de las causas que condicionan esta situación, radica en la generación de resistencia frente a fármacos por parte de las mPCs. Este mecanismo de resistencia a fármacos (DR) se ha visto que no solo depende de factores intracelulares, sino que la propia interacción de las mPCs con el microambiente medular juega un papel fundamental para su supervivencia, crecimiento y desarrollo de DR. Entre los componentes del microambiente tumoral, destaca la adhesión de las mPCs a componentes de la matriz extracelular (ECM) que se ha visto relacionada con la generación de DR. Por este motivo el desarrollo de esta tesis doctoral consistió en la elaboración y validación de una plataforma de cultivo 3D basado en la síntesis de un microgel. Este sistema estará constituido por microesferas funcionalizadas con componentes de la ECM como son la fibronectina (FN), colágeno tipo I (COL), heparina (Hep), heparan sulfato (HS) y ácido hialurónico (HA), generando un entorno 3D biomimético con la capacidad de poder analizar la respuesta celular desencadenada por la interacción de las mPCs con los componentes de la ECM, así como la DR generada por la adhesión de las mPCs a estas biomoléculas.

El primer estudio consistió en la realización y puesta a punto de varios protocolos para la síntesis de distintos microgeles; un primer sistema se produjo mediante la polimerización por vía radical en bloque de co-polímeros de poliacrilato de etilo (EA) y polimetacrilato de etilo (EMA) o bien por EA, EMA y ácido acrílico (AAc). Mediante una emulsión del tipo aceite en agua se consiguió producir con estos copolímeros, microesferas de un tamaño próximo al de las mPCs. Un segundo sistema se basó en microesferas de alginato. Estas microesferas se obtuvieron en un dispositivo de microfluidica produciéndose la gelificación externa de las micro-gotas con la incorporación de iones de calcio consiguiendo microesferas de un tamaño medio de $177 \mu \mathrm{m}$. Debido a la gran variedad de microesferas sintetizadas con diferentes grupos químicos en sus superficies, se consiguió establecer protocolos de funcionalización similares a los establecidos en la literatura, 
teniendo en cuenta la estabilidad de la biomolécula a lo largo del tiempo del cultivo celular. Este enfoque, permitió la funcionalización con una gran variedad de biomoléculas disponiendo así de microgeles funcionalizados con FN, COL, Hep, HS y HA.

Una vez desarrollados los microgeles, en un segundo estudio se procedió a evaluar la respuesta celular en un entorno 3D basado en microgel, valorando la interacción con los componentes de la ECM. Entre los resultados observados se pudo determinar como el tamaño de las microesferas afecta al crecimiento celular incluso en ausencia de cualquier funcionalización. Con los microgeles constituidos por microesferas de un tamaño próximo al de las mPCs se obtuvo un mayor crecimiento celular que con los microgeles formados por partículas de mayor tamaño, y en ambos el crecimiento fue superior al del cultivo en suspensión. Se plantea la hipótesis de que la presencia de las microesferas favorece en gran medida que se produzca un mayor contacto célula-célula que se ve incrementado cuanto mayor es la superficie específica del microgel. Entre los componentes de la ECM estudiados, mientras que el COL no genera ninguna respuesta celular diferente al control (microgel no funcionalizado), el HA favorece la proliferación celular. La adhesión de las mPCs a la FN condiciona el bloqueo de las células en la fase $\mathrm{G}_{0}-\mathrm{G}_{1}$ del ciclo celular. Esta adhesión está mediada por la integrina $\alpha_{4} \beta_{1}$. Al incrementar la actividad de la integrina $\beta_{1}$ mediante la incorporación de cationes divalente $\mathrm{Mn}^{2+}$ se consiguió aumentar la adhesión de las mPCs a la FN, observando de manera independiente que el incremento de la actividad de la integrina $\beta_{1}$ reduce el crecimiento celular. En el caso de la Hep y HS los resultados mostrados hacen indicar que ambas biomoléculas tienen un efecto nocivo para la célula, presentando en ambas condiciones una elevada mortalidad. Estos resultados junto a que ninguno de los microgeles no funcionalizados generó citotoxicidad, permitieron validar el desarrollo de una plataforma de cultivo 3D en donde los componentes de la ECM son capaces de interaccionar con las mPCs generando una respuesta celular diferente según la biomolécula de estudio.

Por último, para corroborar que nuestra plataforma puede ser útil en la valoración de la respuesta a fármacos, se estudió la DR generada por la adhesión de las mPCs a los componentes de la ECM empleando dexametasona (DEX) y bortezomib (BRZ). Los resultados indicaron que mientras las condiciones de microgel sin funcionalizar no generan ningún tipo de interferencia con los fármacos, los microgeles funcionalizados con HA, COL y FN a través de su adhesión a las mPCs fueron capaces de desarrollar resistencia frente a la DEX, fenómeno observado en la literatura en el caso del HA y FN 
y que ha sido un hallazgo novedoso en el caso del COL. Estas adhesiones no generaron ningún tipo de DR frente a BRZ. Una de las características del BRZ es reducir la expresión de la integrina $\alpha_{4} \beta_{1}$. Dado que la adhesión de las mPCs a la FN esta mediada por esta integrina, la acción conjunta de DEX y BRZ, permitió por acción del BRZ revertir la adhesión de las células a la FN, siendo nuevamente las mPCs susceptibles a la acción de la DEX. 


\section{Resum}

El mieloma múltiple és una neoplàsia hematològica caracteritzada per una expansió descontrolada de cèl-lules plasmàtiques monoclonals (mPCs) en medul·la òssia que produeixen, en la majoria dels casos, un component monoclonal secretat en el sèrum i/o en orina. En l'actualitat, es continua considerant una malaltia incurable, amb la constant aparició de recaigudes en els pacients. Una de les causes que condicionen aquesta situació, radica en la generació de resistència enfront de fàrmacs per part de les mPCs. Aquest mecanisme de resistència a fàrmacs (DR) s'ha vist que no sols depèn de factors intracel·lulars, sinó que la mateixa interacció de les mPCs amb el microambient medul·lar juga un paper fonamental per a la seua supervivència, creixement i desenvolupament de DR. Entre els components del microambient tumoral, destaca l'adhesió de les mPCs a components de la matriu extracel-lular (ECM) que s'ha vist relacionada amb la generació de DR. Per aquest motiu, el desenvolupament d'aquesta tesi doctoral va consistir en l'elaboració i validació d'una plataforma de cultiu 3D basada en la síntesi d'un microgel. Aquest sistema estarà constituït per microesferes funcionalitzades amb components de l'ECM com són la fibronectina (FN), col·lagen tipus I (COL), heparina (Hep), heparan sulfat (HS) i àcid hialurònic (HA), generant un entorn 3D biomimètic amb la capacitat de poder analitzar la resposta cel-lular desencadenada per la interacció de les mPCs amb els components de la ECM, així com la DR generada per l'adhesió de les mPCs a aquestes biomolècules.

El primer estudi va consistir en la realització i posada a punt de diversos protocols per a la síntesi de diferents microgels; un primer sistema es va produir mitjançant la polimerització per via radical en bloc de copolímers de poliacrilat d'etil (EA) i polimetacrilat d'etil (EMA), o bé per EA, EMA i àcid acrílic (AAc). Mitjançant una emulsió del tipus oli en aigua es va aconseguir produir amb aquests copolímers, microesferes d'una grandària pròxima al de les mPCs. Un segon sistema es va basar en microesferes d'alginat. Aquestes microesferes es van obtenir en un dispositiu de microfluidica produint-se la gelificació externa de les microgotes amb la incorporació d'ions de calci aconseguint microesferes d'una grandària mitjana de $177 \mu \mathrm{m}$. A causa de la gran varietat de microesferes sintetitzades amb diferents grups químics en les seues superfícies, es va aconseguir establir protocols de funcionalització similars als establerts 
en la literatura, tenint en compte l'estabilitat de la biomolècula al llarg del temps del cultiu cel-lular. Aquest enfocament va permetre la funcionalització amb una gran varietat de biomolècules disposant així de microgels funcionalitzats amb FN, COL, Hep, HS y HA. Una vegada desenvolupats els microgels, en un segon estudi es va procedir a avaluar la resposta cel-lular en un entorn 3D basat en microgel, valorant la interacció amb els components de l'ECM. Entre els resultats observats es va poder determinar com la grandària de les microesferes afecta el creixement cel-lular fins i tot en absència de qualsevol funcionalització. Amb els microgels constituits per microesferes d'una grandària pròxima al de les mPCs es va obtenir un major creixement cel·lular que amb els microgels formats per partícules de major grandària, i en tots dos el creixement va ser superior al del cultiu en suspensió. Es planteja la hipòtesi que la presència de les microesferes afavoreix en gran manera que es produïsca un major contacte cèllulacèl-lula que es veu incrementat com més gran és la superfície específica del microgel. Entre els components de l'ECM estudiats, mentre que el COL no genera cap resposta cel-lular diferent del control (microgel no funcionalitzat), l'HA afavoreix la proliferació cel·lular. L'adhesió de les mPCs a la FN condiciona el bloqueig de les cèl·lules en la fase $\mathrm{G}_{0}-\mathrm{G}_{1}$ del cicle cel·lular. Aquesta adhesió està intervinguda per la integrina $\alpha_{4} \beta_{1}$. En incrementar l'activitat de la integrina $\beta_{1}$ mitjançant la incorporació de cations divalents $\mathrm{Mn}^{2+}$ es va aconseguir augmentar l'adhesió de les mPCs a la FN, observant de manera independent que l'increment de l'activitat de la integrina $\beta_{1}$ redueix el creixement cel-lular. En el cas de la Hep I HS els resultats mostrats fan indicar que totes dues biomolècules tenen un efecte nociu per a la cèl-lula, presentant en ambdues condicions una elevada mortalitat. Aquests resultats al costat del fet que cap dels microgels no funcionalitzats va generar toxicitat, van permetre validar el desenvolupament d'una plataforma de cultiu 3D on els components de l'ECM són capaços d'interaccionar amb les mPCs generant una resposta cel·lular diferent segons la biomolècula d'estudi.

Per últim, per corroborar que la nostra plataforma pot ser útil en la valoració de la resposta a fàrmacs, es va estudiar la DR generada per l'adhesió de les mPCs als components de l'ECM utilitzant dexametasona (DEX) i bortezomib (BRZ). Els resultats van indicar que mentre les condicions de microgel sense funcionalitzar no generen cap mena d'interferència amb els fàrmacs, els microgels funcionalitzats amb $\mathrm{HA}, \mathrm{COL}$ i FN mitjançant la seua adhesió a les mPCs van ser capaços de desenvolupar resistència enfront de la DEX, fenomen observat en la literatura en el cas del HA i FN i que ha sigut una 
troballa nova en el cas del COL. Aquestes adhesions no van generar cap mena de DR enfront de BRZ. Una de les característiques del BRZ és reduir l'expressió de la integrina $\alpha_{4} \beta_{1}$. Atès que l'adhesió de les mPCs a la FN està intervinguda per aquesta integrina, l'acció conjunta de DEX y BRZ, va permetre per acció del BRZ revertir l'adhesió de les cèl-lules a la FN, sent novament les mPCs susceptibles a l'acció de la DEX. 


\section{Summary}

Multiple myeloma is a haematological neoplasm characterized by an uncontrolled expansion of monoclonal plasma cells (mPCs) in bone marrow that produce, in most cases, a monoclonal component secreted in serum and/or urine. At present, it is still considered an incurable disease with the constant appearance of relapses in patients. One of the causes that condition this situation lies in the generation of drug resistance by the mPCs. This mechanism of drug resistance (DR) has been seen to depend not only on intracellular factors, but the very interaction of $\mathrm{mPCs}$ with the medullary microenvironment plays a fundamental role in their survival, growth and development of DR. Among the components of the tumor microenvironment, the adhesion of the mPCs to components of the extracellular matrix (ECM) stands out, which has been related to the generation of DR. For this reason, the development of this doctoral thesis consisted in the elaboration and validation of a 3D culture platform based on the synthesis of a microgel. This system will be made up of micropsheres functionalized with the components of the ECM such as fibronectin (FN), collagen type I (COL), heparin (Hep), heparan sulphate (HS) and hyaluronic acid (HA), generating a 3D biomimetic environment with the ability to analyse the cellular response triggered by the interaction of mPCs with the ECM components, as well as the DR generated by the adhesion of the mPCs to these biomolecules.

The first study consisted in the realization and development of several protocols for the synthesis of different microgels. A first system was produced by the radical block polymerization of polyethylene acrylate (EA) and polymethacrylate (EMA) co-polymers or by EA, EMA and acrylic acid (AAc). By means of an oil-in-water emulsion technique, it was possible to produce, with these copolymers, microspheres of a size close to that of the mPCs. A second system was based on alginate microspheres. These microspheres were obtained in a microfluidic device producing the external gelification of the microdrops with the incorporation of calcium ions, obtaining microspheres with an average size of $177 \mu \mathrm{m}$. Due to the great variety of microspheres synthesized with different chemical groups on their surfaces, it was possible to establish functionalization protocols similar to those established in the literature, taking into account the stability of the biomolecule along with the time of cell culture. This approach allowed for functionalization with a 
great variety of biomolecules, having in this way functionalized microgels with FN, COL, Hep, HS and HA.

Once the microgels were developed, a second study was carried out to evaluate the cell response in a 3D microgel-based environment, assessing the interaction with the components of the ECM. Among the results observed, it was possible to determine how the size of the microspheres affects cell growth even in the absence of any functionalization. With the microgels constituted by microspheres close to the size of the mPCs, a greater cellular growth was obtained than with the microgels formed by larger particles, and in both the growth was higher than in suspended culture. It is hypothesized that the presence of microspheres greatly favours a greater cell-cell contact, which is increased the larger the specific surface area of the microgel. Among the components of the ECM studied, while the COL does not generate any cellular response different from the control (non-functionalized microgel), HA favours cell proliferation. The adhesion of mPCs to FN conditions the blocking of cells in the $\mathrm{G}_{0}-\mathrm{G}_{1}$ phase of the cell cycle. This adhesion is mediated by the integrin $\alpha_{4} \beta_{1}$. By increasing the activity of the integrin $\beta_{1}$ by incorporating divalent $\mathrm{Mn}^{2+}$ cations, the adhesion of mPCs to FN was increased, independently observing that the increase in the activity of the integrin $\beta_{1}$ reduces cell growth. In the case of Hep and HS the results shown indicate that both biomolecules have a harmful effect on the cell, presenting in both conditions a high mortality. These results, together with the fact that none of the non-functionalized microgels generated cytotoxicity, allowed for validating the development of a 3D culture platform where the components of the ECM are able to interact with the mPCs, generating a different cellular response according to the biomolecule of study.

Finally, to corroborate that our platform can be useful in the evaluation of the response to drugs, we studied the DR generated by the adhesion of the mPCs to the components of the ECM using dexamethasone (DEX) and bortezomib (BRZ). The results indicated that while non-functionalized microgel conditions do not generate any type of interference with drugs, HA, COL and FN functionalized microgels through their adhesion to mPCs were able to develop resistance to DEX, a phenomenon observed in the literature in the case of HA and FN and which has been a novel finding in the case of COL. These adhesions did not generate any type of DR against BRZ. One of the characteristics of BRZ is the downregulation of integrin $\alpha_{4} \beta_{1}$. Given that the adhesion of mPCs to FN is 
mediated by this integrin, the joint action of DEX and BRZ allowed BRZ to reverse the adhesion of cells to FN, making mPCs again susceptible to the action of DEX. 


\section{Glossary}

\begin{tabular}{|c|c|}
\hline OAAc & Acrylic material without acrylic acid \\
\hline $\mathbf{O A M}$ & Uncoated acrylic microspheres without acrylic acid \\
\hline 0АMß1 & Uncoated acrylic microspheres without acrylic acid with $\mathrm{MnCl}_{2}$ \\
\hline 2D & Conventional 2D culture \\
\hline 2Dß1 & Conventional 2D culture with $\mathrm{MnCl}_{2}$ \\
\hline 5AAc & Acrylic material with $5 \%$ of acrylic acid \\
\hline 5AM & Uncoated acrylic microspheres with $5 \%$ of acrylic acid \\
\hline 7-AAD & 7-Amino-Actinomycin D \\
\hline AAc & Acrylic acid \\
\hline AGM & Uncoated alginate microspheres \\
\hline Akt & Protein kinase $\mathrm{B}$ \\
\hline APRIL & Proliferation-inducing ligand \\
\hline Bcl-xL & B-cell lymphoma-extra large \\
\hline BCMA & B-cell maturation antigen \\
\hline BM & Bone marrow \\
\hline ВМНер & $\begin{array}{l}\text { Acrylic microspheres with 5\% of acrylic acid blocking active } \\
\text { ester before the coating with heparin }\end{array}$ \\
\hline BMHS & $\begin{array}{l}\text { Acrylic microspheres with 5\% of acrylic acid blocking active } \\
\text { ester before the coating with heparan sulphate }\end{array}$ \\
\hline BMSCs & Bone marrow stromal cells \\
\hline BRZ & Bortezomib \\
\hline CAM-DR & Cell adhesion-mediated drug resistance \\
\hline CHL & Chloroform \\
\hline COL & Type I collagen \\
\hline COLM & Alginate microspheres coated with last layer of collagen type I \\
\hline DEX & Dexamethasone \\
\hline DNA & Deoxyribonucleic acid \\
\hline DR & Drug resistance \\
\hline EA & Ethyl acrylate \\
\hline ECM & Extracellular matrix \\
\hline EDC & 1-Ethyl-3-(3-dimethylamino-propyl) carbodiimide hydrochloride \\
\hline EDTA & Ethylenediamine tetra-acetic acid \\
\hline EMA & Ethyl methacrylate \\
\hline ETA & Ethanolamine \\
\hline FAK & Focal adhesion kinase \\
\hline FBS & Fetal bovine serum \\
\hline
\end{tabular}




\begin{tabular}{|c|c|}
\hline FC & Flow cytometry \\
\hline FESEM & Field emission scanning electron microscope \\
\hline FN & Fibronectin \\
\hline FNB1 & $\begin{array}{l}\text { Acrylic microspheres without acrylic acid coated } \\
\text { with fibronectin and with } \mathrm{MnCl} 2\end{array}$ \\
\hline FTIR & Fourier transform infrared spectroscopy \\
\hline GAGs & Glycosaminoglycans \\
\hline HA & Hyaluronic acid \\
\hline HAM & Alginate microspheres coated with last layer of hyaluronic acid \\
\hline Hep & Heparin \\
\hline HEPES & 4-(2-Hydroxyethyl)-1-piperazineethanesulfonic acid \\
\hline HS & Heparan sulphate \\
\hline HSCs & Haematopoietic stem cell \\
\hline Ig & Immunoglobulin \\
\hline IGH & Immunoglobulin heavy chain gene \\
\hline Igk & Immunoglobulin kappa light chain \\
\hline $\operatorname{Ig} \lambda$ & Immunoglobulin lambda light chain \\
\hline IL & Interleukin \\
\hline LBS & Lysis buffer solution \\
\hline I-PCs & Long-lived plasma cells \\
\hline MAP & Mitogen-activated protein \\
\hline Mcl-1 & Myeloid cell leukemia 1 \\
\hline MFN & Acrylic microspheres without acrylic acid coated with fibronectin \\
\hline MHер & Acrylic microspheres with 5\% of acrylic acid coated with heparin \\
\hline MHS & $\begin{array}{l}\text { Acrylic microspheres with 5\% of acrylic acid } \\
\text { coated with heparan sulphate }\end{array}$ \\
\hline MIX & $\begin{array}{l}\text { Microgel consisting of 50\% alginate microspheres coated with last } \\
\text { layer of hyaluronic acid and 50\% with last layer of collagen type I }\end{array}$ \\
\hline MM & Multiple myeloma \\
\hline mPCs & Monoclonal plasma cells \\
\hline MRD & Minimal residual disease \\
\hline MSCs & Mesenchymal stem cells \\
\hline NF-кB & Nuclear factor-kappa B \\
\hline NHS & N-hydroxysuccinimide \\
\hline $\mathbf{P} / \mathbf{S}$ & Penicillin/streptomycin \\
\hline PBS & Phosphate-buffered saline \\
\hline PCs & Plasma cells \\
\hline PEA & Poly (ethyl acrylate) \\
\hline PEO & Poly (ethylene glycol) bis (3-aminipropyl) terminated \\
\hline PI3K & Phosphoinositide 3-kinase \\
\hline PVA & Poly (vinyl alcohol) \\
\hline RNA & Ribonucleic acid \\
\hline
\end{tabular}




\begin{tabular}{|c|c|}
\hline RNase & Ribonuclease \\
\hline SHP2 & Src-homology 2 domain-containing tyrosine protein phosphatase-2 \\
\hline SmIg & Surface membrane immunoglobulins \\
\hline s-PCs & Short-lived plasma cells \\
\hline SUSP & Suspension culture without microspheres \\
\hline SUSP及1 & Suspension culture without microspheres with $\mathrm{MnCl}_{2}$ \\
\hline UPW & Ultrapure water \\
\hline VCAM-1 & Vascular cell adhesion protein 1 \\
\hline VLA-4 & Very late antigen-4 \\
\hline
\end{tabular}




\section{Introduction}

\subsection{Haematopoiesis and B cell differentiation}

Haematopoiesis is the physiological process that leads to the formation of blood cells. Human haematopoiesis has different anatomical locations throughout embryonic and postnatal development. During embryonic development, haematopoiesis begins mainly at the yolk-sac stage from precursors with haematopoietic and endothelial differentiation capacity (1). In the postnatal stage, the bone marrow (BM) is the main organ for the generation of haematopoietic cells under physiological and pathological conditions. Haematopoiesis is a hierarchical system in which the most immature cells proliferate and differentiate into mature and functional forms based on physiological needs. They are grouped by functional and phenotypical level into various cell types: haematopoietic stem cells (HSCs), haematopoietic progenitor cells, precursor cells committed to a certain lineage, and mature cells (2).

B cell precursor cells develop from HSCs and differentiate into distinctive stages of maturation in the BM, where the medullary stromal cells are essential in the development of lymphoid B cells by providing specific cell-cell contacts and soluble cytokines $(3,4)$. These stromal cells which include osteoblasts, osteoclasts, along with other haematopoietic cells such as $\mathrm{T}$ cells and dendritic cells (5) provide specific niches by supplying the necessary microenvironment for each specific subset of developing B cells (6). The expression of a variety of surface and intracellular proteins and the state of reassembly of the immunoglobulin (Ig) genes have allowed for the identification, so far, of five stages of maturation of B cells. These stages of maturation are known as: pro-B cells, pre-BI cells, pre-BII cells, immature cells and naïve B-lymphocytes $(7,8)$. The very early B cell precursors from the HSC develop in the BM to form the pro- and pre-B cell stages and migrate to the blood. They emerge into the peripheral blood as immature cells and arrive at the peripheral lymphatic organs as mature naïve cells. They then form either within the extra-follicular sites of secondary lymphoid organs into short-lived plasma cells (s-PCs), which are proliferating cells with a life span of 3-5 days, or in the germinal 
centers into long-lived plasma cells (l-PCs), which are non-proliferating cells with a life span of several months. These 1-PCs are stimulated during germinal center reactions into secreting high-affinity class-switched antibodies, and migrate back to the BM, where they differentiate into immobile mature plasma cells (PCs), the BM being their main survival niche (Figure 1) (9,10). It is currently unknown whether s-PCs and 1-PCs belong to completely separate plasma cell populations or if the s-PCs differentiate into 1-PCs (10). Khodadadi et al. hypothesized in 2019 (10) that an s-PCs could become an 1-PCs within a plasma cell survival niche, which would allow for its differentiation into an 1-PCs or otherwise remain an s-PCs and die.

During the differentiation process, already in the early stages, pro-B cells begin to rearrange the various genes of the Ig chains by somatic recombination between the diversity (D) and joining (J) segments of the Ig heavy chain gene (IGH) (11). The rearrangement stage of the IGH locus is completed with the attachment of a variable (V)segment to the DJ splice. This functional VDJ exon is then spliced to the exon of the constant region of the $\mu$ isotype to generate a heavy chain of cytoplasmic Ig $\mu$, which would correspond to the pre-B cell population (12). The light chain genes (Igא or Ig $\lambda$ ) are then rearranged to finally allow for the assembly of both chains, resulting in a complete surface membrane Ig (SmIg), corresponding to an immature lymphoid B cell (11). These immature cells (after going through a negative selection process to eliminate those lymphocytes whose antigen receptors bind strongly to self-antigens presented in the lymphoid organs) will become naïve B cells with only one type of light chain (SmIgא or $\operatorname{SmIg} \lambda$ ), presenting in normal conditions a cell population of plasma cells with a polyclonal ratio of $\operatorname{Ig} \kappa$ to $\operatorname{Ig} \lambda$ (Figure 1) $(11,13)$. 


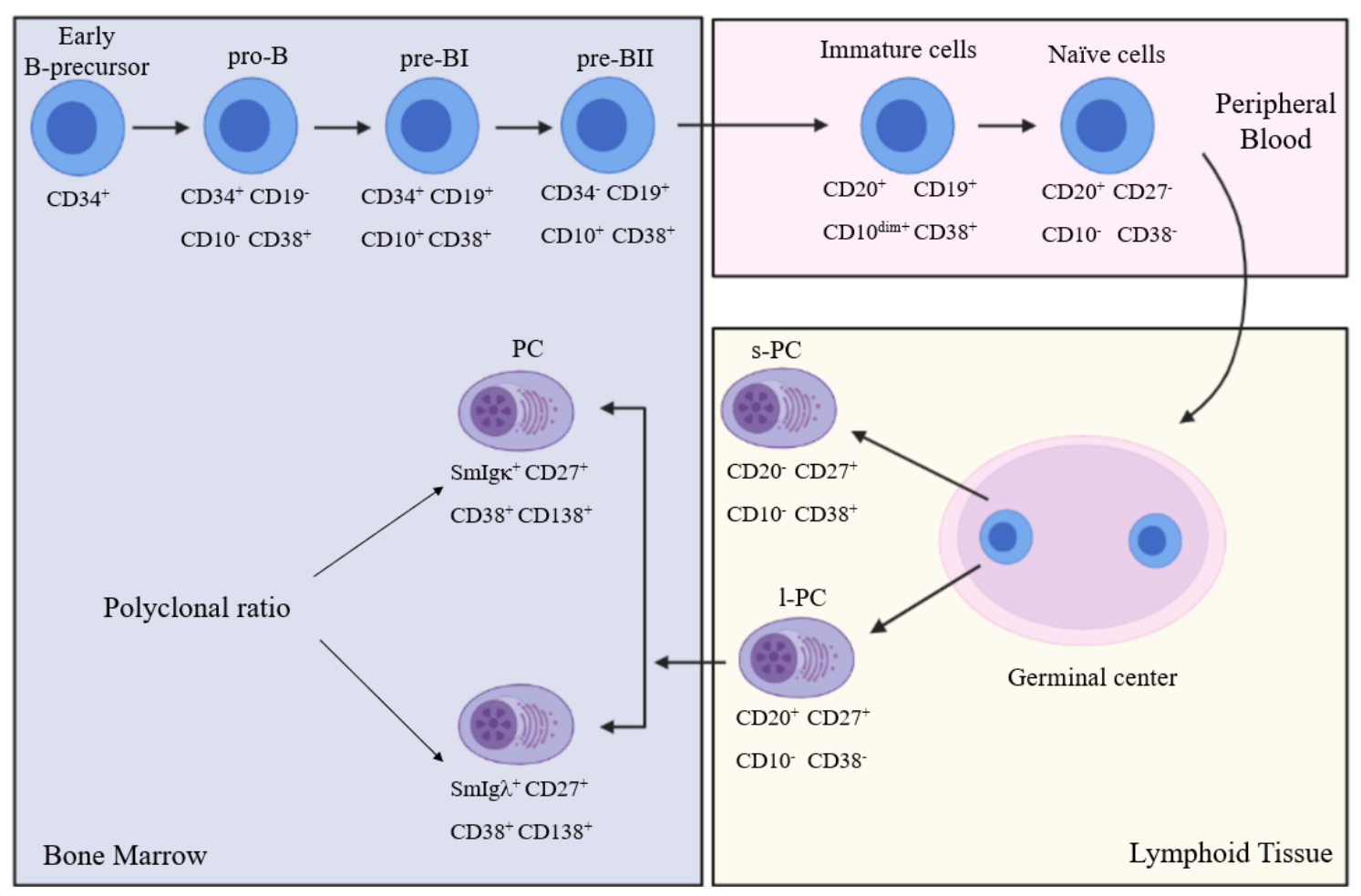

Figure 1. Graphic representation of the different stages of B cell maturation in each of the biological compartments and the generation of plasma cells. SPC (short-lived plasma cell); 1-PC (long-lived plasma cell); PC (plasma cell). (Based on Johnsen et al. 2016 [9])

\subsection{Multiple myeloma}

Multiple myeloma (MM) is a B cell haematologic malignancy characterized by an infiltration of monoclonal plasma cells (mPCs) with heterogeneous localization in the BM compartment (14). In the great majority of patients, the neoplastic PCs secrete a protein that is either a complete Ig or an Ig light chain (e.g., Bence Jones proteins found in urine). Clinical consequences are secondary to either the local effects of the neoplastic proliferation (e.g., lytic bone lesions) or to the distant effects resulting from the deposition of the secreted Ig proteins produced by mPCs (e.g., myeloma nephropathy) (15). MM accounts for approximately $10 \%$ of all haematological malignancies and $2 \%$ of all cancers $(16,17)$, with an average age of 70 years at presentation and diagnosis, being an uncommon disease in ages younger than 40 years (18). As far as the clinical pathology, patients can have anemia or suffer skeletal, renal and/or neurological effects, among others (19). The development of osteolytic bone lesions is the most characteristic of MM, occurring in $80 \%$ of patients at the time of diagnosis $(14,20)$. This is due to the fact that, 
during the progression of the disease, MM induces osteoclastic activity, causing bone breakdown. This osteoclastic activity releases growth factors that enhance the expansion and progression of $\mathrm{MM}$ in the $\mathrm{BM}$ niche, resulting in an increase of osteoclastic activity, in a process known as the vicious cycle (21). In the case of anemia, this is found in approximately $75 \%$ of patients at the time of diagnosis and results from the infiltration of mPCs into the BM, leading to a crowding out and reduction in the number of erythroid precursors (20), which is further accentuated by the induction of erythroblast apoptosis by MM cells (22). The treatment used for MM has improved over time since the initial use of melphalan that had a survival of only 2-3 years. To improve the efficacy of treatment, polychemotherapy regimens were designed using vincristine, adriamycin and dexamethasone (DEX), achieving a good response in young patients mainly due to the use of high doses of dexamethasone. The use of multi-drug combinations has been one of the most widely used strategies against MM, leading to a wide variety of combinations that have improved the survival rate of the disease, due especially to the inclusion of new drugs such as proteasome inhibitors like bortezomib (BRZ), immunomodulators (thalidomide, lenalidomide) and monoclonal antibodies (elotuzumab) $(18,19)$. However, despite the therapeutic advances, MM remains in most cases an incurable disease due to the presence of residual and resistant clones that cause the appearance of repeated relapses in patients (23).

One of the most used drugs for in vitro studies are glucocorticoids, a group of steroid hormones used in the treatment of MM which includes DEX. Glucocorticoids bind to cytosolic glucocorticoid receptors which are then translocated into the nucleus to modulate gene expression (24). The genes regulated in response to DEX include genes related to cellular growth and survival, such as the induction of genes encoding for mitogen-activated protein (MAP) kinase phosphatase, which inactivates growth-related MAP kinase, resulting in the downregulation of anti-apoptotic genes, such as the B-cell lymphoma-extra large (Bcl-xL) gene (25), thus favouring programmed cell death. The action of DEX has also been associated with the inhibition of the nuclear factor-kappa $B$ $(\mathrm{NF}-\kappa \mathrm{B})$ activity. NF- $\mathrm{BB}$ is a major transcriptional factor that participates in many processes through the expression of multiple proteins, including cell adhesion molecules. $\mathrm{NF}-\kappa \mathrm{B}$ activation has been shown to promote the growth, survival, and drug resistance (DR) of MM (26). Moreover, the induction of apoptosis by DEX is mediated via related tyrosine focal adhesion kinase (FAK) activation, through caspase-9 activation, the 
upregulation of pro-apoptotic genes and activation of intrinsic apoptotic pathways $(24,26)$. Resistance to DEX can result from the presence of a functional defect on glucocorticoid receptors of the mPCs. The interaction between mPCs and the microenvironment has also been found to be important in the generation of DR to DEX, where the binding of MM cells to bone marrow stromal cells (BMSCs) results in an increased secretion of pro-survival cytokines, such as interleukin-6 (IL-6). IL-6 protects against DEX-induced apoptosis via phosphoinositide 3-kinase (PI3K)/ protein kinase B (Akt) signaling and activation of the Src-homology 2 domain-containing tyrosine protein phosphatase-2 (SHP2), which blocks tyrosine FAK activation $(26,27)$. Furthermore, the extracellular matrix (ECM) components of the BMSCs have an important relationship in DR as mPCs-fibronectin (FN) adhesion is associated with DR to DEX (28).

Autophagy, or the degradation of potentially toxic oxidized or misfolded proteins, is an important process for cell homeostasis that is mediated primarily by the ubiquitinconjugating system and proteasome (29). Because of the importance of this process for cell survival, one of the drugs used in MM is the proteasome inhibitor BRZ, a dipeptidyl boronic acid that selectively inhibits the ubiquitin proteasome pathway by binding to the catalytic site of the $26 \mathrm{~S}$ proteasome, inducing cell death through various pathways, including: cleavage of survival proteins, such as myeloid cell leukemia 1 (Mcl-1) protein, triggering a stress response to the accumulation of misfolded proteins, inducing cytotoxicity via activation of caspase- 8 and/or -9 , and inhibiting NF- $\kappa$ B activity $(30,31)$. Hatano et al. observed in 2009 (32) that the use of BRZ produced a downregulation of integrin $\alpha_{4} \beta_{1}$ (very late antigen-4 [VLA-4]), that allows for the RPMI 8226 cell line to overcome the CAM-DR effect to DEX. However, this downregulation, which could initially be related to the inhibition of $\mathrm{NF}-\kappa \mathrm{B}$, is also independent of $\mathrm{NF}-\kappa \mathrm{B}$ (26), requiring further studies to better understand the mechanism used by BRZ to downregulate VLA-4. Although the treatment with BRZ has offered generally favourable results, the existence of patients with resistance to BRZ is a negative prognostic factor, due to the incidence of genetic alterations such as deletion of chromosomal region $8 \mathrm{p} 21$ or the presence of mutations in the XBP1 gene (30). Another mechanism related to BRZ resistance may occur due to modifications in the subunits of the proteasome that include the target of BRZ, making the cells less sensitive to the action of BRZ (33).

As for the etiology of the disease, the origin of MM is still uncertain. However, the characteristic monoclonal component of $\mathrm{MM}$ and other haematological malignancies 
such as acute myeloid and lymphoblastic leukemia suggest the existence of a stem cell with the ability to self-renew and differentiate into the predominant lineages of malignant cells $(9,34,35)$. In the case of MM the cell of origin would arise from a peripheral lymph node germinal center, and then differentiate in the BM into a premalignant plasma cell, giving rise to an initial benign neoplasm known clinically as a monoclonal gammopathy of undetermined significance (MGUS), but which through the accumulation of additional genetic "hits" over time could result in cells that would promote the dissemination of a medullary neoplasm into multiple BM sites. This progression is clinically known as MM (Figure 2) (9,36).

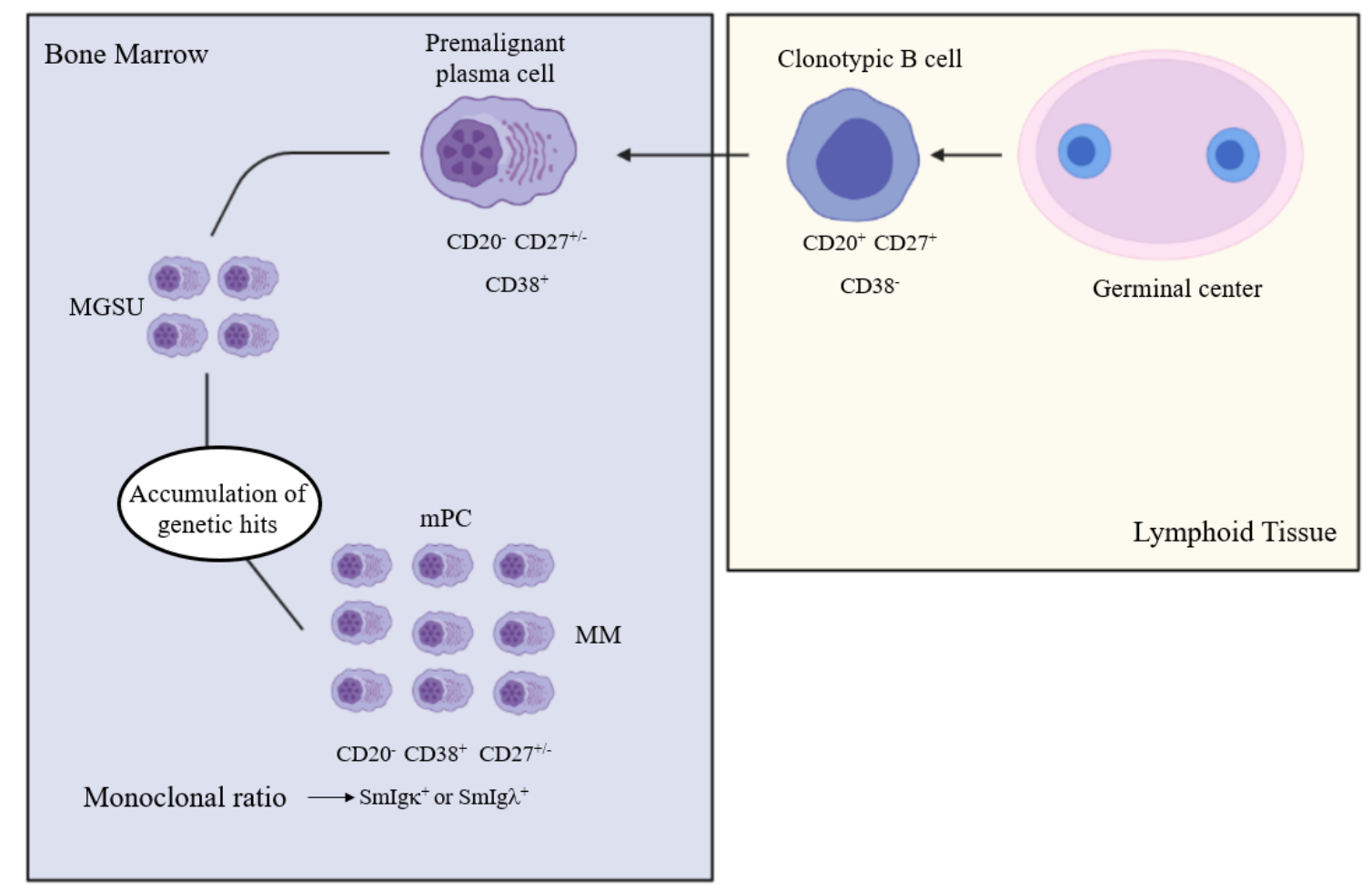

Figure 2. Graphic representation of the etiology of multiple myeloma. MGUS (monoclonal gammopathy of undetermined significance); mPC (monoclonal plasma cell); MM (multiple myeloma). (Based on Johnsen et al. 2016 [9])

Another characteristic that makes $\mathrm{MM}$ a complex disease is the presence of intraclonal heterogeneity, which suggests the possibility that mPCs acquire genetic alterations at random to generate populations of subclones, resulting in the selection of those with aberrations that present a greater advantage for cell survival (36). This could be related to the development of clinical relapses, since by choosing therapies that target a specific mutation within the tumor cells, the main clone would be affected but would 
leave unaffected residual clones that could cause the disease to reappear (37). This has a certain relationship with the "multistep-oncogenesis" theory, in which malignancy is developed due to a series of molecular alterations that occur in PCs (9). In early stages of the disease, it has been observed that these secondary genetic events that promote the progression of the disease can be triggered by the interaction of tumor cells and the microenvironment (36), so that both spontaneous intracellular genetic alterations as well as the interaction of mPCs with the microenvironment have important roles in the development of the disease.

\subsection{Influence of the bone marrow microenvironment on the maintenance and survival of plasma cells}

We have shown above how the maturing lymphoid B cells and developing PCs pass through different biological compartments, each of them presenting a singular cellular and molecular environment. However, the BM constitutes the main niche for PCs, playing an important role in their maintenance and survival in healthy patients, being at the same time a crucial factor in the survival of mPCs and in the generation of DR in patients $(10,38)$. The BM is physiologically a hypoxic environment, and two different regions can be differentiated according to the distribution of $\mathrm{O}_{2}: 1$ ) the endosteal niche, located at the bone-BM interface characterized by high levels of hypoxia and 2) the central vascular niche which due to its proximity to endothelial sinuses and oxygenated blood circulation has less pronounced hypoxia. It is postulated that both regions have a key role in supporting the function of HSCs, keeping them either in a quiescent and immature state (in the more hypoxic endosteal niche) or encouraging their maturation and proliferation (in the more oxygenated vascular niche), locating the PCs in this area $(39,40)$. The BM microenvironment consists of a cellular and non-cellular compartment. The cellular compartment is composed of haematopoietic cells (myeloid cells, $\mathrm{T}$ and B lymphoid cells, NK cells) and non-haematopoietic cells (fibroblasts, osteoblasts, mesenchymal stem cells (MSCs), endothelial cells, endothelial progenitor cells, pericytes). These populations of different types of BM cells together constitute the 
BMSCs. The non-cellular compartment is formed by soluble factors (cytokines, growth factors, chemokines) and ECM components (laminin, collagen type I (COL) and IV, FN and the glycosaminoglycans (GAGs): heparan sulphate (HS), hyaluronic acid (HA) and chondroitin sulphate) (38).

\subsubsection{Influence of the bone marrow microenvironment on the maintenance and survival of normal plasma cells}

The lifespan of the PCs results from the interaction of this cell with the BM microenvironment (41). Among the components involved in the survival of the PCs are included the BMSCs that through the release of APRIL (a proliferation-inducing ligand) and their junction with PCs receptors BCMA (B-cell maturation antigen) and CD138 (syndecan-1) promote PCs survival by inducing the anti-apoptotic molecule Mcl1 of the bcl-2 family $(10,42)$. As commented above, one of the characteristics of the BM is its hypoxic condition, and similar to this the culture of PCs under hypoxic conditions presented a greater survival in vitro than under a normoxic state, hypoxia being a relevant factor for the survival of PCs (43). As for the soluble factors involved in the survival of PCs it is possible to find the cytokine IL-6 (41), which is produced by a variety of cells such as BMSCs, megakaryocytes and eosinophils among others and activates signaling pathways such as JAK/STAT that promotes Mcl-1 (44,45). In the case of megakaryocytes and eosinophils their survival is associated with their ability to secrete both APRIL and IL-6 (46,47). As for the involvement of adhesion molecules expressed by PCs, there is the VLA-4 integrin with the ability to bind to FN or to the vascular cell adhesion protein 1 (VCAM-1) of BMSCs. The adhesion of VLA-4/VCAM-1 promotes in vitro survival of PCs due to the induction by BMSCs of IL-6 (48). CD44 is another adhesion molecule in the PCs that binds to HA, where Cassese et al. in 2003 (41) observed in vitro that the binding of PCs-HA with the incorporation of exogenous IL-6 produced a synergistic activity that promoted the survival of PCs. Finally, one of the most characteristic adhesion molecules of the PCs is CD138 which through its HS chains is able to bind to a large number of proteins such as cytokines, growth factors and ECM components such as COL, providing a survival advantage by increasing IL-6 and APRIL signaling (49). 


\subsubsection{Influence of the bone marrow microenvironment on the maintenance and survival of monoclonal plasma cells}

As we have seen above, the BM microenvironment allows, through cellcell and cell-environment interaction, for mechanisms that increase the lifespan of PCs. However, in the case of MM patients the interaction of the BM microenvironment with the mPCs promotes the growth and development of the disease. This is due to the presence of a tumoral microenvironment in which, in addition to the mPCs, the cells that form the microenvironment are also abnormal (50). This is observed in the interaction of PCs with osteoblasts where, whereas in a normal BM microenvironment there is a balance between osteoclastic bone resorption and osteoblastic bone formation, in the case of MM there is a dysregulation of this process resulting in an enhancement of osteoclastic bone resorption and a suppression of bone formation (51). This dysregulation was observed to be related to the presence, in MM patients with bone injury, of the DKK1 protein, an antagonist of the Wnt/ $/$-catenin signaling pathway essential for normal bone physiology, thereby preventing the osteogenic differentiation of the MSCs that then remain in an immature stage. These immature MSCs express higher levels of IL-6 that promote the survival of mPCs, developing a tumor microenvironment between MSCs and MM cells that results in an increase of bone destruction and MM proliferation $(52,53)$. This synergy is further accentuated by the release by the osteoclasts of APRIL, which binds to mPCs via syndecan-1, promoting their survival (54). In addition, observed genetic differences between MSCs from the BM of MM patients and from healthy patients, where the MSCs of MM patients had an overexpression of genes that code for proteins involved in MM cell growth, angiogenesis and osteoblast differentiation, corroborate that disease progression depends not only on mPCs but also on the presence of abnormal stromal cells that promote the generation of a tumoral environment (50).

This MM environment is made up of a multitude of interactions that favour not only the maintenance and proliferation of the disease but also the generation of DR, which prevents the effective treatment of MM and promotes the occurrence of relapse (38). These relapses arise out of the clinical condition known as "minimal residual disease" (MRD), which refers to the persistence of the disease due to the presence of resistant $\mathrm{mPCs}$ that are undetectable by standard morphology-based diagnostic tests, requiring additional sensitive techniques such as flow cytometry (FC) or molecular 
techniques (55). As for DR this can be acquired or de novo. Acquired DR occurs as a result of sequential genetic and epigenetic changes that ultimately, after drug selection, confer on the tumor cells a complex DR phenotype that can be studied in vitro by chronic exposure of cells to a cytotoxic agent, until a stable DR phenotype is selected $(38,56)$. De novo DR is present before treatment exposure and selection for $\mathrm{DR}$, and is produced by the interaction of mPCs with the cellular microenvironment which protects cells from chemotherapy, radiotherapy or receptor-targeting drugs due to the presence of soluble factors that mediate DR or by the adhesion of mPCs to stromal cells and/or to the ECM components that allows for the generation of DR, a phenomenon known as cell adhesionmediated drug resistance (CAM-DR) $(38,56,57)$.

This Thesis will focus on the mechanisms associated with de novo DR that may contribute to the failure to eliminate MRD and facilitate the emergence of acquired DR (56), more specifically those that are related to the interaction between cell-ECM components. Paiva et al. in 2016 (58) observed that MM cells in MRD presented an overexpression of integrins and adhesion molecules even as compared to the cells at first diagnosis, which suggests that cell-ECM component interaction involved in the generation of the CAM-DR effect could also be responsible for the generation of in vivo resistant clones that condition the MRD.

\subsection{Interaction between monoclonal plasma cells and extracellular matrix components and their effect on cell adhesion-mediated drug resistance}

Among the ECM components involved in the mPCs-ECM interaction and the CAM-DR effect we can include:

- FN: a dimer of 235-250-kDa subunits in which each subunit is composed of an array of 12 type I, 2 type II and 15-17 type III modules, the last one with a $30 \mathrm{kDa}$ heparin-binding fragment called HepII domain, containing the CS-1 and H1 regions $(59,60)$. FN is implicated in a multitude of processes such as angiogenesis, vascular remodeling, cell adhesion and migration, being one of the most studied ECM components in MM pathogenesis $(38,59)$. In particular, the cell adhesion 
between the mPCs and FN has been seen to generate a CAM-DR effect against DEX, with the integrins, a family of cell surface receptors, playing a key role in the mPCs-FN interaction. MM cells express the VLA-4 integrin on their surface, which through its binding to the $\mathrm{H} 1$ or predominantly $\mathrm{CS}-1$ region of $\mathrm{FN}$, allows for mPCs-FN adhesion $(61,62)$. This adhesion induces the downregulation of Jab1 $(28,62)$, which prevents the phosphorylation of $\mathrm{p} 27^{\mathrm{Kip} 1}$ on serine 10 and with it the nuclear export of $\mathrm{p} 27^{\mathrm{kip} 1}$. The resulting increase in $\mathrm{p} 27^{\mathrm{kip} 1}$ intranuclear protein levels inhibits cyclin A- and cyclin E-dependent CDK2 kinase activity $(28,38,62)$. As a result there is a cell-cycle arrest at $\mathrm{G}_{0}-\mathrm{G}_{1}$ stage and, as a consequence, an intrinsic DR against DEX which has been demonstrated in the RPMI 8226 MM cell line (28). Since the interaction is mediated by VLA-4 it is not surprising that one of the in vitro strategies used to reverse the CAM-DR effect is through downregulation of VLA-4 expression on MM cells, as brought about by, among other agents, the action of BRZ (32). Furthermore, as this adhesion is mediated by integrin, the integrin needs to be in an active state to be able to join its ligand. The presence of divalent cations such as $\mathrm{Mn}^{2+}$ has been shown to favour the activity of the integrin $\beta_{1}$, causing an upregulation of MM cell adhesion to FN (61).

- HA: a GAG composed of alternating $(1>4)-\beta$ linked D-glucuronic and $(1>3)-\beta$ linked $\mathrm{N}$-acetyl-D-glucosamine residues. It is a major component of the ECM presented in mammalian BM, articular cartilage, and synovial fluid (63). GAGs have the ability to bind and enhance the activities of cytokines and growth factors involved in the generation of DR (64). In the case of HA, the mPCs-HA binding is mainly mediated by the adhesion molecule CD44. HA-mediated proliferation of mPCs occurs through an IL-6 autocrine pathway associated with a downregulation of $\mathrm{p} 27^{\mathrm{kip} 1}$ and a hyperphosphorylation of the retinoblastoma protein (65). As for DR produced by HA adhesion, it has been shown to be related with $\mathrm{Wnt} / \beta$-catenin activation that promotes $\mathrm{MM}$ cell resistance to lenalidomide (66). Also, by the use of different MM cell lines it was possible to observe how the DR against DEX mediated by HA adhesion was produced by different signaling pathways, inducing STAT3 phosphorylation in IL-6-dependent MM cell lines that are associated with the upregulation of the Bcl-xL anti-apoptotic protein, 
whereas, in IL-6-independent MM cell lines, resistance is due to the upregulation of bcl-2 and the activation of NF- $\mathrm{BB}(64)$.

- HS: a GAG that is ubiquitously expressed on cell surfaces and in the ECM. Each HS molecule is a linear polysaccharide composed of repeating disaccharide units, which, in their unmodified form, are formed by D-glucosamine and D-glucuronic acid, while heparin (Hep) is a highly sulphated form of HS $(67,68)$. Due to their unique structural features, HS and Hep can bind a wide range of bioactive molecules such as growth factors and chemokines that regulate important cell behaviours in normal and pathological processes. This ability to modulate many growth factor signaling pathways makes HS play an important role in the regulation of the tumor microenvironment through the control of tumor growth, angiogenesis, and metastasis $(69,70)$. The expression of HS proteoglycan syndecan-1 is a hallmark of MM and crucial for promoting growth and survival signaling. The chains of HS syndecan-1 are indispensable for the growth of MM and related to the generation of DR. Reijmers et al. showed in 2013 (67) how by targeting the HS synthesis machinery, MM cells improve their sensitivity to lenalidomide and BRZ.

- Collagen: the most abundant protein in the human body and the most prevalent component of the ECM. There are 28 different types of collagen, of which, COL, the most abundant form, is a heterotrimer composed of two $\alpha 1$ chains and one $\alpha 2$ chain (71). The interaction between mPCs-COL is mediated by syndecan-1 (72), which is known to play a role in mediating MM cell interaction with the BM niche and recently has been shown to promote Wnt/ $\beta$-catenin signaling. Wnt signaling is associated with MM proliferation, dissemination, DR and disease progression $(73,74)$. 


\section{$1.52 \mathrm{D}$ vs. 3D culture systems}

Considering the importance of the ECM components in their interaction with mPCs and in the generation of the CAM-DR effect, cell-based assays have been an important pillar of drug evaluation by performing part of these tests on conventional 2D culture models (75). However, the differences seen between pre-clinical and clinical assays prove the failure of these conventional 2D cell cultures to generate a cellular response similar to that which might occur in vivo $(76,77)$. One of the reasons that $2 \mathrm{D}$ cultures are not representative is the lack of reproducibility of the in vivo architecture and microenvironment (78), since they consist in a cell monolayer expanding on a tissue culture polystyrene plastic flask (75). They typically develop a slower tumor progression and lower DR rate compared to in vivo tumors cells, leading to reduced efficiency of drug detection and testing (79). For this reason, the design of 3D culture systems is increasingly relevant for developing platforms that are more predictable and similar to in vivo models (76). Among the $3 \mathrm{D}$ models it is possible to find organotypic cultures which have the advantage of preserving the structural and synaptic organization of the original tissue $(76,80)$. Spherical cell clusters formed by self-assembly, denominated spheroids, is another of the most common methods in $3 \mathrm{D}$ culture (81). The special feature of the spheroids is that within the spheroid structure there is a heterogeneity of cell population, generated by the presence of oxygen and nutrient gradients. Cells in a stage of proliferation are located in the outer layer of the spheroid, where they are exposed to nutrients from the culture medium, while closer to the nucleus of the spheroid, possibly due to the lack of oxygen and nutrients, cells are found in a quiescent state, this heterogeneity being a relevant component for in vivo tissues, organs, and even tumors $(78,81)$. However, when the culture times are prolonged, the viability can be reduced due to the lack of oxygen and nutrients and the accumulation of residues in the core of the spheroid as it grows $(75,82)$. In addition to the cell-cell contact, the interaction of cellECM components is also crucial in vivo, and must be introduced in the in vitro models. Tissue engineering strategies allow for developing hydrogels and other $3 \mathrm{D}$ environments, including in its composition ECM biomolecules that act as a synthetic ECM. Macroporous scaffolds have also been developed with a wide variety of synthetic polymers such as polyethylene oxide, polyvinyl alcohol (PVA), polyacrylic acid and naturally derived materials like HA, collagen, gelatin, alginate, and agarose $(78,83)$. 
Alginate is an organic linear polysaccharide consisting of the alternating blocks of $(1 \rightarrow 4)$ linked $\beta$-D-mannuronate and $\alpha$-L-guluronate residues, and is the most highly employed polymer matrix because of its nontoxicity, biocompatibility and easy gel-making ability $(84,85)$. Alternatively, polyethyl acrylate is characterized as being a polymer with a low hydrophilicity, elastomeric at body temperature, having mechanical properties close to those of the soft biological tissues, and having a broad range of properties which make it suitable for supporting various cell cultures as an ECM $(86,87)$. One of the culture methods used for cell-ECM adhesion is through the denominated microcarriers, that consist of microspheres with an approximate average size from $90 \mu \mathrm{m}$ to $350 \mu \mathrm{m}$, whose surface is adherent to the cells. These microspheres can be functionalized with ECMbased materials, suspended in a culture medium by gentle stirring. In spite of being cultures in suspension, the adhesion of cell-microcarrier makes cells proliferate as in a monolayer culture. Moreover, due to their high surface-to-volume ratio, high cell densities are achieved in relatively low volumes $(88,89)$. As for the study of microcarriers, most of them have been used to expand MSCs, and it has been possible to verify how cell attachment and behaviour change according to the physical properties of the microcarrier, such as rugosity, topography, curvature, elastic modules and stiffness (89). One of the problems with the small size of the microspheres is that the characterization of the stiffness and elastic modules is difficult to perform by conventional deformation systems (90). In spite of this, studies in 2D cultures reveal the importance of this parameter in the behaviour of MSCs, as the stiffness of the material will promote the differentiation of the MSCs towards different lineages: a rigid surface (stiffness of $34 \mathrm{kPa}$ ) leading to an osteogenic differentiation, low stiffness of $1 \mathrm{kPa}$ promoting neuronal, chondrogenic and adipogenic differentiation, and intermediate stiffness favouring the muscular lineage (89). As for the attachment of cells as a function of the roughness of the material, in fibroblasts it was observed that cells adhered more easily to smooth microcarriers than on microcarriers with higher roughness (91). 


\subsection{D multiple myeloma culture platforms}

Regarding $\mathrm{MM}$, due to the great influence of the $\mathrm{BM}$ environment in the generation of DR, the development of 3D systems has become one of the major current objectives, with the use of different models in the literature using either MM cell lines or primary cells from patients diagnosed with MM. In the case of Jakubikova et al. in 2016 (92), the 3D culture model is performed by encapsulating MSCs from the BM of patients with MM in a commercial hydrogel composed mainly of laminin and collagen IV plus growth factors. Once the expansion of the MSCs has been carried out, the fraction of mononuclear cells is isolated from a BM aspirate from patients with MM, where the mPCs are found, and is added to the surface of the hydrogel, resulting in a static 3D system with cellular components that would be mesenchymal and mononuclear cells and a noncellular component that would correspond to the ECM components from the hydrogel. In a similar way, Kirshner et al. in 2008 (93) performed a static 3D culture incorporating the ECM components such as FN and COL as a coating on the bottom of the wells to subsequently incorporate the fraction of mononuclear cells from $\mathrm{MM}$ patients encapsulated in a matrix composed of FN. The encapsulation of the cells can also be carried out with components from MM patients as in the case of de la Puente et al. in 2015 (94), where they developed a 3D environment through the cross-linking of fibrinogen (derived from the BM supernatant of MM patients) with calcium and then carried out the culture by incorporating the rest of the BM cellular components from MM patients. The characteristic of the above-mentioned cell cultures is that they are static 3D models where the cells are encapsulated in materials composed of ECM components or other proteins available in in vivo models. However, the limitations of these model cultures are that the static condition reduces mass transfer because the hydrogel acts as a barrier to diffusion.

Another 3D system consists in the development of cell cultures in bioreactors which give the culture a dynamic condition that allows, unlike static 3D cultures, for a greater diffusion of gasses and nutrients and non-air-liquid interface (95). One of the commercial bioreactors used in the development of 3D systems is the Rotary Cell Culture System $\left(\mathrm{RCCS}^{\mathrm{TM}}\right)$. This features a horizontally rotated cylinder with a coaxial oxygenator in the center that allows for the suspension of the cells by the resolution of gravitational, 
centrifugal and Coriolis forces (96). This system avoids the shear effect on the cells that is characteristic of the spinner flask, by maintaining cells, spheroid cells or cellular aggregates in suspension with low shear and providing the correct distribution of oxygen and nutrients. In addition, with the help of microcarriers, it also allows for the growth of adherent cells in a dynamic system $(77,97)$. This platform has been used by Ferrarini et al. in 2013 (95), where they observed using tissue from MM patients that the system is also able to preserve the tissue architecture and blood vessel integrity suitable for longterm culture. As for the working group of Belloni et al. in 2018 (77), they also performed the 3D culture of adherent cells in the bioreactor using a gelatin scaffold in which they incorporated primary pooled allogeneic BMSCs and endothelial cells to later perform the co-culture incorporating mPCs from MM patients.

\section{Hypothesis and Objectives}

In the previous section we emphasized the influence of a multitude of factors affecting the development of the disease in MM patients. These are related to the generation of phenotypical and genetic changes in mPCs, conferring DR and consequently the appearance of successive relapses after the treatments. In order to identify the involvement of each of these factors, and their mechanisms of action on tumor cells, it can be very helpful to have realistic disease models in which the object of study can be isolated. In particular, we focus this work to study a 3D culture platform in which the influence of the interaction of MM cells with the different ECM components can be analysed. This model will allow us to identify the interaction of cells with each of the biomolecules of interest in order to study the involvement of each one of them in the generation of DR, so as to contribute to the development of new drugs with specific targets.

Our hypothesis is that in order to reproduce in vitro the conditions in which cells and biomolecules interact, it is necessary, firstly, to have a three-dimensional environment in which these interactions take place, and secondly, to guarantee the mobility of mPCs in 
the cell culture and to favour the diffusion of growth factors and cytokines in the medium as a means of interaction between the cells and ECM without direct contact.

The aim of this Thesis is the design and proof of concept of a 3D culture platform in which the biomolecule or biomolecules of interest are grafted onto the surface of synthetic microspheres. These microspheres and RPMI 8226 MM cell lines are maintained in suspension in a liquid medium so that the cells always have access to the biomolecules. This is what in this Thesis we will call a microgel. In our case the denomination microgel is in fact used for a dispersion of microspheres in a fluid culture medium in which nonencapsulated cells are also dispersed. For the generation of the microgel, different materials will be used, including alginate and acrylate microspheres of different sizes. The functionalization of the surface of these microspheres with ECM components will provide to the culture the generation of an ECM of similar composition to the in vivo one and, at the same time, with the ability to generate a cellular response as near as possible to the in vivo behaviour. In addition, the system will be equipped with an orbital agitation acquiring a dynamic condition that improves the distribution of oxygen and nutrients as well as maintains the culture in suspension. This would enable the development of a dynamic 3D microgel culture, in which cells are dispersed in a culture medium surrounded by functionalized microspheres that would mimic the ECM. The configuration of the platform avoids the limitations of encapsulated cells, as well as the limitations of static cultures.

The specific objectives of the Thesis are:

- Synthesis and functionalization of a variety of biostable and biocompatible microspheres, using methods that can be extended to a wide range of biomolecules.

- Development of a 3D culture platform and analysis of the viability and cell proliferation of mPCs in a microgel environment, with and without the presence of ECM components. 
- Due to the novelty of the system corroborate, by the use of well-studied biomolecules such as FN and HA, that our 3D culture model is capable of reproducing a cellular response and generation of DR derived from the adhesion of the cells to these biomolecules (CAM-DR), as well as the synergy of combining the effect of different drugs, as in the case of DEX and BRZ.

- Exploitation of the novel 3D culture platform, by functionalizing the microgels with other biomolecules such as Hep, HS and COL, whose effect on cell behaviour and CAM-DR is less well understood; and development of a cell culture with microspheres functionalized with different combinations of biomolecules, such as the HA and COL pair, highlighting the versatility of the platform.

\section{Materials and Methods}

\subsection{Synthesis and functionalization}

\subsubsection{Polymerization}

The acrylate microspheres were made from a random copolymer of acrylic acid (AAc), ethyl acrylate (EA) and ethyl methacrylate (EMA) (Sigma-Aldrich, St. Louis, MO, USA), resulting in two different materials according to the presence or absence of AAc. The material was synthesized by a block free radical polymerization protocol, by mixing 50\% EA and 50\% EMA to produce acrylic material without AAc (0AAc), and mixing $47.5 \%$ EA, $47.5 \%$ EMA and 5\% AAc to produce acrylic material with AAc (5AAc). In both cases acetone $30 \% \mathrm{w} / \mathrm{w}$ was used as a solvent. For the initiation of the reaction, $0.5 \%$ of benzoin (Sigma-Aldrich) was used, incubating the solution for 24 hours in an ultraviolet (UV) exposure chamber. The next day, to ensure a complete conversion of the monomer, the material was exposed for 24 hours to a post-polymerization process 
in an oven at $90^{\circ} \mathrm{C}$. After the post-polymerization, the monomer residue and low molecular weight substances remaining after polymerization were removed by dissolving the material in acetone and reprecipitating it with deionized water four times.

\subsubsection{Acrylic microspheres synthesis by emulsion}

The purified copolymer was dissolved in chloroform (CHL, $3 \mathrm{~g} / 100 \mathrm{~mL}$, Scharlab, S.L., Barcelona, Spain) and finally mixed with $5 \% \mathrm{w} / \mathrm{w}$ magnetic ferrite nanoparticles (EMG 1300M, Ferrotec, Santa Clara, CA, USA). The weight fraction was calculated with respect to the weight of the copolymer. The ferrite filler provided the nano-composite microspheres with magnetic properties that made them easy to manipulate and separate from cells or any aqueous medium with the help of a magnet.

The production of 0AAc and 5AAc microspheres was performed by an oil-in-water emulsion technique using $0.5 \%$ aqueous solution of PVA (Sigma-Aldrich) as the continuous phase and 3\% w/v of magnetic copolymer solution in CHL as the dispersed phase. A volumetric flask was used to carry out the emulsion by stirring $200 \mathrm{~mL}$ of the continuous phase at $2000 \mathrm{rpm}$ for 15 minutes. At this point, $20 \mathrm{~mL}$ of the oily phase was added with the help of a funnel, leaving it to agitate for 10 minutes. Later, to promote the evaporation of the CHL, $150 \mathrm{~mL}$ of ultrapure water (UPW) was added, continuing the agitation for 24 hours. After 24 hours the solution was transferred to a beaker stirring at $700 \mathrm{rpm}$ overnight to finish the CHL evaporation and the microspheres formation. Finally, to retain the microspheres, the solution was transferred to $50 \mathrm{~mL}$ tubes to remove the remains of PVA by making a series of four washings with UPW. 


\subsubsection{Alginate microspheres synthesis by microfluidic device}

The production of alginate microspheres was carried out by means of a flowfocusing PDMS microfluidic device (Figure 3) with 500 x $500 \mu \mathrm{m}$ channel size, allowing for the generation of microspheres of different sizes ranging from $170-473 \mu \mathrm{m}$ in diameter with a low size dispersion. For this purpose, an alginate (Sigma-Aldrich) solution in UPW $(1.5 \% \mathrm{w} / \mathrm{v})$ with different flow rates of $0.03,0.13$ and $0.3 \mathrm{~mL} / \mathrm{min}$ was used as a dispersed phase and CHL (Scharlab) with flows of $0.3,1.3,3,5$ and $6.2 \mathrm{~mL} / \mathrm{min}$ as a continuous phase. After the formation of the alginate droplets within the device, external gelation was induced by dropping the microspheres into an external gelation solution of $10 \% \mathrm{w} / \mathrm{v}$ calcium chloride $\left(\mathrm{CaCl}_{2}, \mathrm{Scharlab}\right)$ in UPW, leaving them to agitate at $700 \mathrm{rpm}$ for 30 minutes. Alginate gelation was performed by a well-known method based on the exchange of the sodium ions of glucuronic acid from alginate with the divalent ions from the $\mathrm{CaCl}_{2}$.(84) Once the gelation was completed, three washings with UPW were carried out to remove the CHL with the help of a $70 \mu \mathrm{m}$ filter and to finally retain the microspheres in a $70 \%$ ethanol solution.

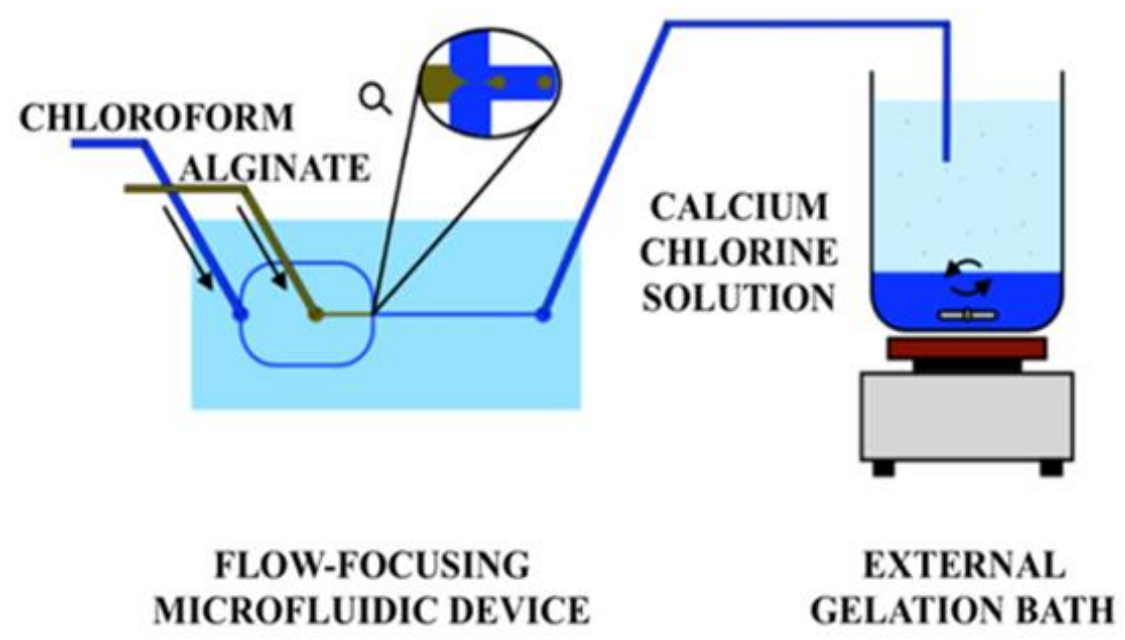

Figure 3. Schematic representation of the of the flow-focusing microfluidic device. 


\subsubsection{Biomolecule grafting using carbodiimide chemistry}

The 5AAc copolymer microspheres present carboxyl groups $(\mathrm{COOH})$ on their surface due to the incorporation of AAc into the copolymer chain. The functionalization with Hep and HS (Sigma-Aldrich) was carried out by the activation of carboxyl groups using 1-ethyl-3-(3-dimethylamino-propyl) carbodiimide hydrochloride (EDC, SigmaAldrich) in combination with N-hydroxysuccinimide (NHS, Sigma Aldrich). This activation allows for the grafting of poly (ethylene glycol) bis (3-aminopropyl) with amine terminal groups (PEO, Sigma Aldrich) onto the surface of the microspheres, leaving a free amine terminal group $\left(-\mathrm{NH}_{2}\right)$. PEO acts as a bridge between the acrylate microsphere surface and the polysaccharide to be grafted, which is required since Hep and HS do not contain reactive groups to bond directly to carboxyl groups. In this way the activation of the carboxylic groups of the polysaccharide allow for the biomolecule to be bonded to the free amine terminal groups of PEO (98).

First, the activation solution was prepared with $1 \mathrm{mg}$ of NHS and $10 \mathrm{mg}$ of EDC per $\mathrm{mL}$ of phosphate-buffered saline (PBS) at $\mathrm{pH}=7.4$ (EDC/NHS). After that, to activate carboxyl-groups, the microspheres were incubated with EDC/NHS solution for 2 hours at room temperature in an orbital agitation. Afterwards, two washes with UPW were performed and then the activated material was incubated with a PEO solution (1.5 mg of PEO per $\mathrm{mL}$ of $\mathrm{PBS}$ at $\mathrm{pH}=7.4$ ) for 24 hours at $37^{\circ} \mathrm{C}$. Three PBS washings were performed to eliminate the remaining PEO. Then, the carboxyl-groups of Hep and HS were activated by dissolving them into a EDC/NHS solution for 2 hours, using $6 \mathrm{mg}$ of heparin per $\mathrm{mL}$ of EDC/NHS solution for Hep, and $200 \mu \mathrm{g}$ per $\mathrm{mL}$ of EDC/NHS solution for HS. Once the carboxyl groups were activated, the Hep or HS were incubated for 24 hours at $37^{\circ} \mathrm{C}$ with the microspheres previously coated with PEO, allowing for the linkage of the biomolecules onto the surface of the material. After the functionalization, the material was washed with $0.5 \mathrm{M}$ citric acid and then with $0.1 \%$ Triton $\mathrm{X}-100$, leaving the material in sonication for 5 min each time and then washing two times with UPW. Finally, the material was incubated in a $1 \mathrm{M}$ ethanolamine (ETA) solution (Sigma-Aldrich) at $\mathrm{pH}$ 9 for 1 hour at $4^{\circ} \mathrm{C}$, and washed three times in UPW, keeping the material in a sodium chloride solution in UPW (5\% w/v), to prevent the agglomeration of the microspheres. 


\subsubsection{Biomolecule coating by physical adsorption}

Functionalization of 0AAc microspheres was performed on the same day as cell seeding, by coating them with $20 \mu \mathrm{g} / \mathrm{mL}$ of FN from human plasma (Sigma-Aldrich) by physical adsorption for 1 hour (99) and washed twice with RPMI 1640 culture medium without fetal bovine serum (FBS, Gibco, Thermo Fisher).

\subsubsection{Coatings through a layer-by-layer technique}

The functionalization of the alginate microspheres was performed by a layer-bylayer (LbL) electrostatic self-assembly in which alternating layers of COL (Advanced BioMatrix, Inc., San Diego, CA, USA, 97\% Type I atelocollagen) and HA (SigmaAldrich) are deposited one over the other, due to the electrostatic difference between the COL and HA layers, following the protocol described by Zhao et al. 2014 (100). Both COL and HA were dissolved in UPW at a concentration of $1 \mathrm{mg} / \mathrm{mL}$ with agitation overnight at $4^{\circ} \mathrm{C}$ and balanced at $\mathrm{pH} 5$ with a HEPES buffer (4-(2-hydroxyethyl)-1piperazineethanesulfonic acid) (Sigma-Aldrich). Alginate microspheres were immersed in UPW at pH 5 to make their surface negatively charged (101). LbL was performed by alternated immersion, in orbital agitation at $600 \mathrm{rpm}$, in COL solution (positively charged at $\mathrm{pH}$ 5) for 20 minutes, and HA solution (negatively charged at $\mathrm{pH}$ 5) for 15 minutes, with a wash of UPW at pH 5 between them. By repeating those steps, multilayers were built up to 9 and 10 layers, respectively.

\subsubsection{Sterilization and disinfection}

The sterilization and disinfection protocols were different for each microsphere type. In the case of 5AAc microspheres, as the functionalization process cannot be performed under sterile conditions and because Hep and other GAGs are sensitive to UV radiation (102), sterilization by UV-exposure was discarded. Moreover, due to the acrylic composition of the microspheres, the use of ethanol also dissolves the material. For this reason, a disinfection protocol was used incubating the microspheres in a PBS solution with $3 \%$ penicillin/streptomycin (P/S) and $4 \mu \mathrm{g} / \mathrm{mL}$ of amphotericin B at $37^{\circ} \mathrm{C}$ 
overnight. The next day, two washes were performed with PBS, incubating again in a PBS solution with $1 \% \mathrm{P} / \mathrm{S}$ and $2 \mu \mathrm{g} / \mathrm{mL}$ of amphotericin $\mathrm{B}$ at $37^{\circ} \mathrm{C}$ overnight, washing them again with RPMI 1640 culture medium without FBS, to then be ready to start the cell culture.

For 0AAc microspheres, since the functionalization of the microspheres with FN is performed on the same day as the cell seeding, it is possible to sterilize the material before the coating by UV-exposure. To do this, the material was exposed to UV light for 30 minutes and then incubated in a PBS solution with $3 \% \mathrm{P} / \mathrm{S}$ at $37^{\circ} \mathrm{C}$ overnight. The next day, two PBS washes were performed, keeping them again in UV light for 30 minutes, incubating them in a PBS solution with $1 \% \mathrm{P} / \mathrm{S}$ at $37^{\circ} \mathrm{C}$ overnight, and washing them again with PBS.

Finally, for alginate microspheres, once the functionalization is done, due to the risk of collagen photo-degradation (103) and since GAGs are sensitive to UV radiation (102), sterilization of the microspheres by UV-exposure was also discarded. Therefore, with the help of a $70 \mu \mathrm{m}$ filter and under sterile conditions, microspheres were sterilized by washing them three times with a $70 \%$ ethanol solution, followed by six washes with PBS to remove the remaining alcohol, and finally three more washes with RPMI 1640 culture medium.

\subsection{Characterization}

\subsubsection{Physical characterization of the microspheres}

Microsphere size and surface were observed under a Field Emission Scanning Electron Microscope (FESEM, ULTRA 55 model, ZEISS, Oberkochen, Germany). In the case of acrylate microspheres, the samples are prepared by drying them in air at room temperature and mounted to FESEM. In the case of alginate microspheres the visualization of the microspheres by FESEM was done by treating the sample in a fixation protocol that consisted in the immersion of the microspheres for 30 minutes in a $3 \%$ glutaraldehyde solution (Sigma-Aldrich) in PBS, and then washed twice in PBS for 10 minutes. Dehydration of the sample was then performed by the immersion of the microspheres in a UPW solution with increasing ethanol content of 30, 50, 70, 80, 90, 95, 
100,100 and $100 \%$ in this specific order for 10 minutes each. The samples were dried by supercritic fluid drying in a Leica EM CPD300 apparatus (Leica Microsystems Inc., Buffalo Grove, IL, USA) and mounted to FESEM. Microspheres were then prepared in a P24 well to assess the dispersion of the acrylate microspheres in culture conditions, after manual stirring. Measurements were performed in a stereo zoom microscope (MZ APO model, Leica Microsystems, Wetzlar, Germany) of the dispersion of the acrylate microspheres in culture conditions, after manual stirring. Diameter distribution of the microspheres was determined using ImageJ software (National Institutes of Health, MD, USA) from which mean values and standard deviation was calculated for each system.

\subsubsection{Glycosaminoglycan quantification}

The quantitative characterization of Hep and $\mathrm{HS}$ on the surface of 5AAc microspheres was determined by using the Blyscan ${ }^{\mathrm{TM}}$ Glycosaminoglycan Assay Kit (Biocolor Ltd, Carrickfergus, UK) with the standard protocol of the kit. Uncoated acrylic microspheres with $5 \%$ of acrylic acid (5AM) were used as a baseline, performing the assay in triplicate, as measured on a Victor3 Plate Reader (PerkinElmer, Waltham, MA, USA) and evaluated at $660 \mathrm{~nm}$.

\subsubsection{Protein quantification}

In order to quantify the total amount of protein on acrylic microspheres without acrylic acid being coated with fibronectin (MFN) or on alginate microspheres being coated with collagen type I (COLM), the characterization of the microspheres was performed by a Micro-BCA assay using a Pierce BCA Protein Assay Kit (Thermo Fisher Scientific, Waltham, MA USA), following the standard protocol of the kit to quantify the total amount of FN or COL after each coating, using as a baseline uncoated acrylic microspheres without AAc (OAM) or uncoated alginate microspheres (AGM), respectively. The assay was performed in triplicate and quadruplicate, respectively, and measured on a Victor3 Plate Reader (PerkinElmer, Waltham, MA, USA). The results were evaluated by averaging the values recorded at 570 and $550 \mathrm{~nm}$. 


\subsubsection{Spectroscopy detection}

The qualitative characterization of the presence of $\mathrm{COL}$ and $\mathrm{HA}$ on alginate microspheres and the difference between 0AAc and 5AAc microspheres was assessed by Fourier Transform Infrared Spectroscopy (FTIR, Bruker Scientific LLC, Billerica, MA, USA) in attenuated total reflectance mode (ATR), detecting the appearance of their specific absorption peaks. Since the sensitivity of the technique is limited when the material is in the form of microspheres, samples in the form of films were prepared and functionalized specifically for this technique. In the case of acrylate material, after polymerization the samples were diluted in acetone $(6 \mathrm{~g} / 100 \mathrm{~mL})$ and then, to obtain the films, the acetone was evaporated first in room conditions and then in a vacuum at $60^{\circ} \mathrm{C}$. For alginate films, alginate gelation was performed in a glass petri dish.

\subsection{Cell culture}

\subsubsection{Cell culture growth protocol}

MM cell line RPMI 8226 cells were grown in 3D and 2D conditions with RPMI 1640 (Gibco), supplemented with 15\% FBS, 1\% L-glutamine (Sigma-Aldrich) and 1\% $\mathrm{P} / \mathrm{S}($ Gibco, $10,000 \mathrm{U} / \mathrm{mL})$ in an incubator at $37^{\circ} \mathrm{C}$ and $5 \% \mathrm{CO}_{2} .5 \times 10^{4}-3.5 \times 10^{5}$ cells were cultured as a suspension culture (3D cultures) in a 24 well plate with an orbital shaker (VWR) at $300 \mathrm{rpm}$ or without agitation (2D culture). Since it is a suspension cell culture, the liquid-medium was partially renewed every day in 3D culture and 2D culture by adding $400 \mu \mathrm{L}$ of fresh medium, stirring for 15 minutes to favour the distribution of nutrients. After that, the stirring was stopped for 1 hour to precipitate cells and microgel, and finally $400 \mu \mathrm{L}$ of culture medium was removed carefully.

\subsubsection{D culture on acrylate microspheres microgels}

The effect of the volume fraction occupied by the microspheres in the 3D culture system was assessed using acrylate microspheres. The total volume in the culture well 
was fixed at $500 \mu \mathrm{L}$. Samples with different 0AM/liquid-medium ratios were prepared to get microgels with 17.2\% v/v of microspheres (M17), 13.8\%v/v (M13), 10.34\% v/v (M10) and $6.89 \% \mathrm{v} / \mathrm{v}(\mathrm{M} 6)$. Once the volume percent was decided, cell culture assays were performed using two control conditions: the conventional culture in which cells drop to the bottom of the well, which we will call 2D control (2D), and a suspension culture without microspheres (SUSP) in which cells are maintained in suspension by orbital stirring. Cell culture in microgels was performed with OAM, 5AM, MFN and acrylic microspheres with 5\% of AAc coated with Hep (MHep) or HS (MHS) (Figure 4).

Cell seeding was performed in triplicate in P24 plates. Microgel and cell suspension in culture medium were added consecutively in the proper ratios to obtain the desired volume fraction of microspheres. In the case of FN experiments, to ensure the initial adhesion to $\mathrm{FN}$, thus avoiding the adhesion of the cells to the other proteins present in the FBS that can be adsorbed onto the surface of the microspheres, cells were first seeded in culture medium without FBS for 1 hour without stirring. After one hour the appropriate amount of FBS was added to each of the wells.

For FC assay the magnetic acrylate microspheres were separated from the cells using a magnet before the staining protocols to prevent equipment obstruction.

\subsubsection{D culture on alginate microgels}

Microgel platform of alginate microspheres were designed using a microspheres/liquid-medium volume percent of $20 \% \mathrm{v} / \mathrm{v}(100 \mu \mathrm{L}$ wet microspheres/400 $\mu \mathrm{L}$ liquid-medium) where the total volume of the culture medium was $500 \mu \mathrm{L}$. Six series of culture conditions were considered: 2D, SUSP, AGM, alginate microspheres coated with last layer of HA (HAM) or COL (COLM), and a microgel consisting of $50 \%$ of HAM and 50\% of COLM (MIX) (Figure 4). MIX condition was used to test the versatility of the platform to study in a single well the interaction of different ECM components by the incorporation of different coated microspheres. For cell seeding, the microspheres were added in triplicate in a P24 plate and then cells were included in culture medium.

In addition, to prevent FC equipment obstruction by alginate microspheres, samples were passed previously through a $70 \mu \mathrm{m}$ filter. 


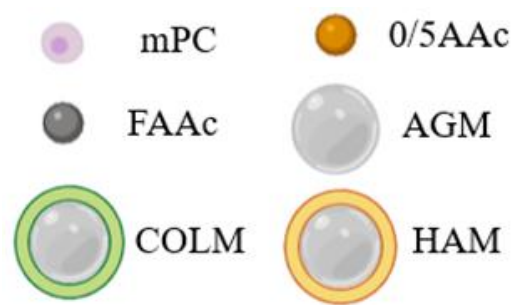

A

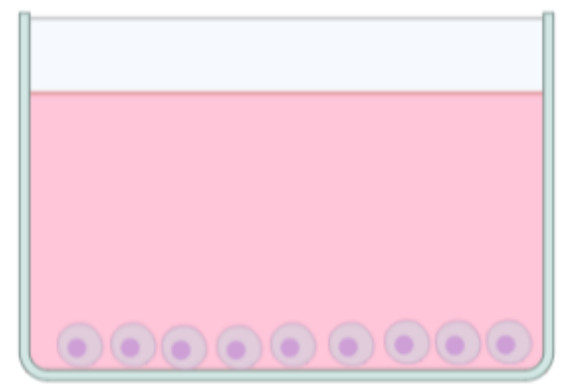

C

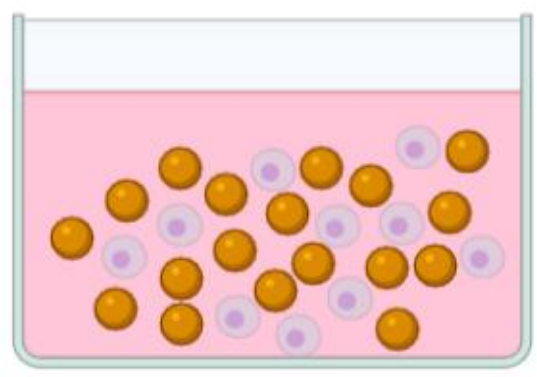

E

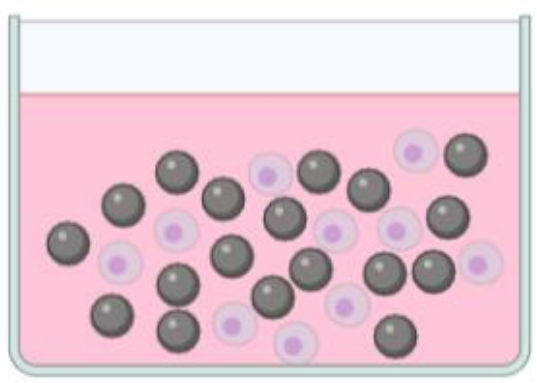

B

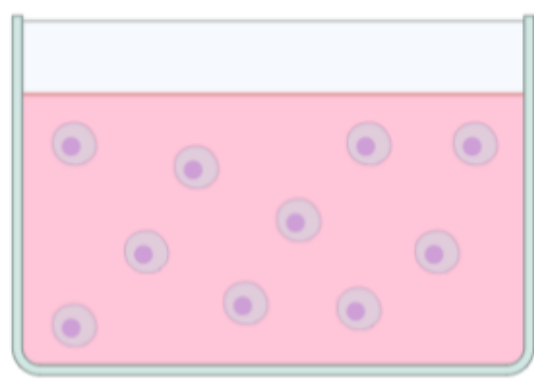

D

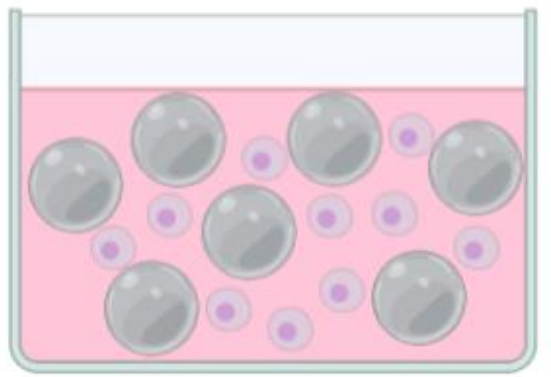

F

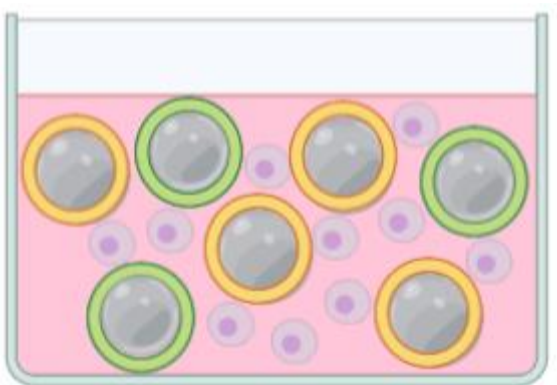

Figure 4. Graphic representation of the different forms of cultivation performed. A) Conventional 2D culture (2D condition). B) Suspension culture (SUSP condition). C) Suspension culture incorporating 0/5AM corresponding with uncoated acrylic microspheres without acrylic acid (0AM condition) or with $5 \%$ of acrylic acid (5AM condition). D) Suspension culture incorporating uncoated alginate microspheres (AGM condition). E and F) Representation of a suspension culture in an environment with components of the extracellular matrix, E) Suspension culture of acrylic microspheres without acrylic acid coated with FN (MFN condition), acrylic microspheres with $5 \%$ of acrylic acid coated with Hep (MHep condition) or HS (MHS condition). F) Suspension culture of microgel consisting of 50\% of alginate microspheres with a last layer of HA and 50\% of COL (MIX condition). mPC: monoclonal plasma cell, FAAc: Functionalized acrylic microspheres with FN, Hep or HS, AGM: alginate microspheres, HAM: alginate microspheres with a last layer of HA, COLM: alginate microspheres with a last layer of COL, FN: fibronectin, Hep: heparin, HS: heparan sulphate, HA: hyaluronic acid, COL: collagen type I. 


\subsubsection{Proliferation and cell cycle assay}

The proliferation assay was carried out using the Quant-iT PicoGreen dsDNA kit (Invitrogen, Thermo Fisher) and cell cycle assay. Quant-iT PicoGreen dsDNA kit measure the total amount of DNA of the samples. For this reason, to make DNA accessible, a cell digestion of the samples was performed with a lysis buffer solution (LBS) prepared for $100 \mathrm{~mL}$ : $0.653 \mathrm{~g}$ of sodium phosphate dibasic (Panreac Quimica SLU, Barcelona, Spain), $0.648 \mathrm{~g}$ of sodium phosphate monobasic (Panreac), and $1 \mathrm{~mL}$ of ethylenediamine tetra-acetic acid (EDTA) (Gibco, 0.5 M) dissolved in UPW at pH 6.5. On the day of the digestion, $3.875 \mathrm{U} / \mathrm{mL}$ of papain (Sigma-Aldrich) and $1.5 \mathrm{mg} / \mathrm{mL}$ of Lcysteine were added to the LBS, and then $500 \mu \mathrm{L}$ were added to each sample with the corresponding microspheres and kept under agitation at $60^{\circ} \mathrm{C}$ for 18 hours. In the case of alginate microspheres, due to the chelating action of EDTA during the lysis incubation, the microspheres become soluble and there is no need to separate them from the cells; while for acrylate microspheres, it is possible to separate the deoxyribonucleic acid (DNA) fraction from the microspheres with a magnet. Finally, DNA was incubated with the PicoGreen solution following the manufacturer's instructions, using alginate or acrylate microspheres without cells as baseline. Fluorescence was read on an opaque plate Optiplate96F (PerkinElmer) using a Victor3 plate reader (PerkinElmer) at 485/535 nm.

Cell cycle assay was performed by FC with a DNA-PREP reagents kit (Beckman Coulter, San Diego, CA, USA). Once the fraction of the cells was separated from the microspheres, the samples were washed twice with PBS and centrifuged at $300 \mathrm{~g}$ for 5 minutes. Then, $100 \mu \mathrm{L}$ of DNA PREP LPR reagent, a permeabilization solution, were added and vigorously vortexed for 10 seconds. $1 \mathrm{~mL}$ of DNA PREP Stain was added to each sample and incubated in the dark for 30 minutes at room temperature. DNA PREP Stain contains propidium iodide (PI) and ribonuclease (RNAse) to remove cytoplasmic ribonucleic acid (RNA) that could bind with PI and generate false positive results (104). Finally, samples were acquired in a Navios flow cytometer (Beckman Coulter), and data were analysed on Kaluza software Version 2.1 (Beckman Coulter). 


\subsubsection{Viability assay and drug resistance analysis}

Cell viability was assessed by FC using Annexin-V kit (Miltenyi Biotec, Bergisch Gladbach, Germany) and 7-Amino-Actinomycin D (7-AAD, Becton Dickinson, San José, CA, USA). The fraction of cells was washed two times with PBS and resuspended in 300 $\mu \mathrm{L}$ of $1 \mathrm{X}$ binding buffer solution (Miltenyi Biotec). Then, $10 \mu \mathrm{L}$ of Annexin- $\mathrm{V}$ conjugated with fluorescein isothiocyanate (FITC) and $5 \mu \mathrm{L}$ of monoclonal antibody CD138 conjugated (specific antibody to PCs) with BD Horizon V500 (Becton Dickinson) were added and cells were incubated in the dark for 20 minutes at room temperature. After an additional wash with 1-2 $\mathrm{mL}$ of $1 \mathrm{X}$ binding buffer solution, cells were centrifuged at $300 \mathrm{~g}$ for 5 minutes and resuspended in $200 \mu \mathrm{L}$ of $1 \mathrm{X}$ binding buffer solution. Then, $10 \mu \mathrm{L}$ of $7-\mathrm{AAD}$ were added, incubated for 15 minutes in the dark at room temperature and finally the samples were acquired in a FACS Canto-II flow cytometer (Becton Dickinson) and data analysis carried out by Kaluza software.

CAM-DR effect was evaluated by exposing cells to 5-10 nM BRZ (STADA, Bad Vilbel, Germany, $2.5 \mathrm{mg} / \mathrm{mL}$ ) for 48 hours and 1-1,000 $\mu \mathrm{M}$ DEX at $8.75 \mathrm{mg} / \mathrm{mL}$ (fortecortin, Merck KGaA, Darmstadt, Germany) for 72 hours. In addition, a control without drugs was prepared for each of the conditions that was used to normalize each of the CAM-DR condition viability results.

\subsection{Statistical analysis}

Results were analysed by one-way ANOVA using IBM SPSS Statistics software version 20.0. When differences were determined, comparisons were performed using the Bonferroni method, correcting for multiple comparisons. Data was presented as mean \pm standard deviation. $\mathrm{p} \leq 0.05$ was considered statistically significant. 


\section{Results and Discussion}

\subsection{Synthesis and functionalization of different microgels}

The behaviour of mPCs in a 2D culture differs morphologically and physiologically from that generated in a 3D culture (105). Also, the lack of ECM components or stromal cells in 2D cultures, whose interaction with mPCs is related with their survival and the generation of DR (106-108) makes them unrealistic models. The three-dimensional configuration seems necessary to reproduce as closely as possible the BM environment. The development of $3 \mathrm{D}$ culture systems that could mimic the BM tumoral environment and, therefore, generate a cellular response like the one produced in vivo is still a challenge (77,93). mPCs interact with the BM environment, made up of a multitude of components, and these interactions determine their growth, invasion and generation of DR $(21,64,109,110)$. As discussed above, the literature shows some examples of 3D culture models in which the ECM components are part of a medium stiffness 3D support, such as hydrogel or matrigel $(78,83)$, and in other cases adsorbed on or grafted to the bottom of the culture well or dissolved in the culture medium $(64,93)$. Following the advantages and disadvantages of each 3D culture model discussed in section 1.5 and 1.6, it was decided to establish a different 3D culture system based on a microgel, which, by the incorporation of an orbital stirring, creates a dynamic environment that favours the distribution of nutrients and at the same time avoids the precipitation of the microgel and the cells. This dynamic condition enables cell growth in suspension with cell-cell or cellECM component interaction. Grafting of ECM biomolecules on the surface of the microspheres ensures their availability in proximity to the cells, at distances that are in the order of magnitude of cell size. Cell-ECM interactions are thus favoured when compared with other configurations and closer to the natural niche. As cells are neither encapsulated in the microgel nor forming spheroids, they have greater mobility to allow for the interaction with other cells and components of the ECM. All this with the aim of 
achieving homogeneous accessibility of the cells to the ECM components under study throughout the system.

Therefore, the initial step in the development of our 3D culture platform based on microgel consisted in the production of microspheres with different sizes and compositions. As a first reference for the selection of the microparticle size, one can think of the cell expansion platforms based on microcarriers. In these platforms the microspheres are maintained suspended in the liquid culture medium by stirring. The mean diameter of the microcarriers found in the literature or in commercial products varies in a range between $90 \mu \mathrm{m}$ to $350 \mu \mathrm{m}(88,89)$. The purpose of the supporting material is quite different in the case of the culture with microcarriers and in the microgels. While microcarriers are used to support the culture of adherent cells, such as, MSCs, the main function of the microgel in our system is to give support to the ECM components. From that point of view, smaller microspheres could be more suitable. This is why a fixed size for the microspheres that make up the microgel was not marked from the beginning of the work. On the other hand, it must be said that the characteristics of the material used and the manufacturing techniques in each case determine to a certain extent the appropriate particle sizes. Thus, it was not considered appropriate to have acrylate microspheres, which have a certain rigidity, be much larger than cells, because in the agitated system they could damage the cells significantly, while in the case of alginate hydrogel particles the manufacturing protocols did not allow us to obtain small diameter particles in a reproducible way.

The generation of microspheres with different compositions was decided on because this allowed for the adoption of different synthetic routes for functionalization. Microspheres made of synthetic copolymers that present carboxyl groups on their surface allow for direct grafting of amine groups by carbodiimide chemistry, while in the case of microspheres of a polysaccharide, the appearance of a surface density of electric charges allow for functionalization by LbL, which is a very versatile way of presenting to the cells a variety of biomolecules linked to the microsphere surface through electrostatic interactions, without the need for chemical reactions. Microspheres exhibiting a single biomolecule on its surface can be produced, which allows studying the interaction of mPCs with each of them separately. The synergistic study of different biomolecules can be carried out by combining microspheres with different ECM components, which gives the system a great versatility for future studies. 


\subsubsection{Development and functionalization of microgels based on acrylic microspheres}

The acrylic material in the acrylic microspheres is made up of a copolymer containing EA, EMA and, where appropriate, AAc. The microsphere preparation was carried out in two stages. First, flat plates with a thickness around $1 \mathrm{~mm}$ were obtained by free radical polymerization in a mold. The copolymer is polymerized from the mixture of liquid monomers introduced into the mold, using benzoin as a photochemical initiator, which breaks down into free radicals through UV exposure. These free radicals are extremely unstable but at the same time have a great capacity to react, allowing for the addition of the different monomers in a block polymerization process via free radicals, which result in the formation of the copolymer. In the case of the combination of EA, EMA and AAc monomers, linear copolymer chains are formed in which the different monomeric units are randomly distributed along the chain. This random distribution makes the carboxyl groups of AAc naturally appear on the surface of the microsphere. This radical polymerization leaves monomer residues that need to be removed. Although the polymers of the polyacrylate and polymethacrylate series are very biocompatible and biostable in the body, and have been widely used in ophthalmic implants, as bone cements and in other applications, the monomers are cytotoxic due to the high reactivity of the $\mathrm{C}=\mathrm{C}$ double bond present in all the monomers of the series. To remove residual low molecular weight substances from the copolymer after the polymerization reaction, the obtained material is completely dissolved in a good solvent such as acetone. By reprecipitating the copolymer in water, the low molecular weight substances remain soluble and are extracted from the copolymer. In this way, by repeating the process several times, a highly pure material is obtained. Once the pure material is available, it is dissolved in CHL to proceed to the second step, that will consist in the production of the acrylate microspheres by an oil-in-water emulsion technique, in which the coagulation of the copolymer microspheres takes place with the evaporation of CHL through the continuous liquid phase. Since the size of the microspheres can be controlled by varying the stirring speed, it was decided to perform three tests using different speeds at 750 , 1,500 and 2,000 rpm. As shown in Figure 5, as the stirring speed increases, the microsphere size is reduced, obtaining an average size of $27 \pm 13 \mu \mathrm{m}$ at $750 \mathrm{rpm}$ (Figure $5 \mathrm{~A}$ ), $10 \pm 4 \mu \mathrm{m}$ at 1,500 rpm (Figure 5B) and $9 \pm 4 \mu \mathrm{m}$ at 2,000 rpm (Figure 5C). For the cell culture tests, it was decided to use the conditions that produced a microsphere size 
similar to that of the PCs, namely 9-20 $\mu \mathrm{m}$ (111). Although the difference in microsphere size between the 2,000 and 1,500 rpm conditions is minimal, it was observed that a higher speed favoured the evaporation of the CHL, allowing us to achieve at the end of the process a greater efficiency (data not shown). This size distribution does not differ significantly between OAM and 5AM functionalized with Hep, as seen in Figure 5C and 5D. It should be mentioned that the particle size dispersion obtained is characteristic of the bead production by emulsion process and is not considered problematic for our application, since it is not expected that a regularity of particle size would affect the interaction with the cells. In addition, since mPCs have a heterogeneous cell size, this size distribution probably better reflects the in vivo environment.
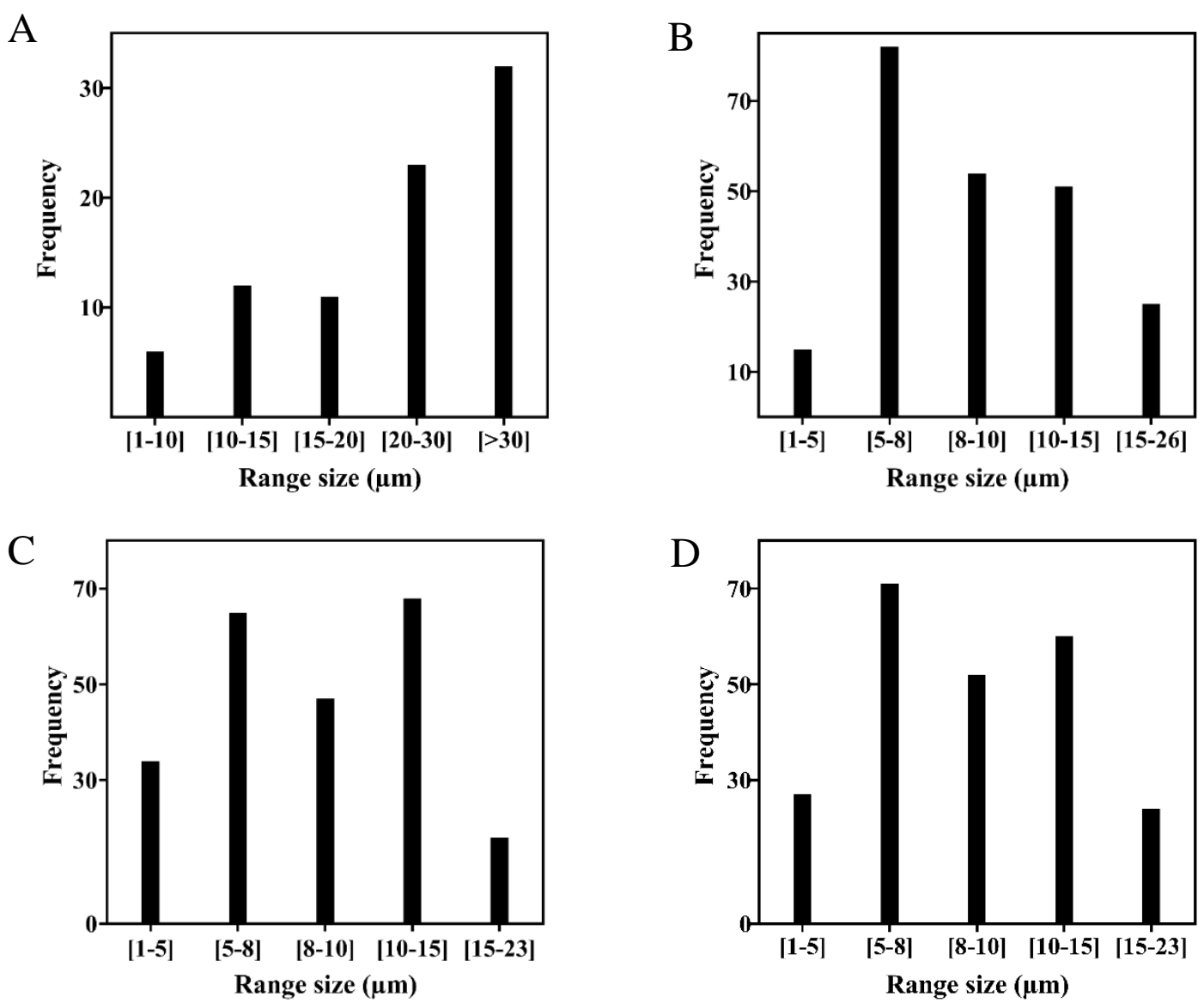

Figure 5. Acrylate size distribution by varying the stirring speed: A) size distribution of $0 \mathrm{AM}$ at $750 \mathrm{rpm}$, B) size distribution of $0 \mathrm{AM}$ at 1,500 rpm, C) size distribution of $0 \mathrm{AM}$ at 2,000 rpm, D) size distribution of MHep at 2,000 rpm. OAM: uncoated acrylic microspheres without acrylic acid, MHep: acrylic microspheres with $5 \%$ of acrylic acid coated with heparin. 
The reason why it was decided to use EA copolymers in this study is mainly due to the ability of polyethyl acrylate (PEA) to induce fibrillation of FN (112-114). Fibrillogenesis of $\mathrm{FN}$ is produced in vivo by the cellular activity within the ECM environment that is crucial in the cell-FN interaction, having demonstrated that on PEArich surfaces the adsorption of $\mathrm{FN}$ forms its characteristic reticulum, maximizing the exposure of the protein adhesion domains (112-114). Our group, in a previous work, performed MSCs culture in a 3D environment consisting of microspheres with a composition analogous to OAAc, coated with FN (99). The same protocol was followed in this work but in this case using a microsphere size of $9 \mu \mathrm{m}$. Thus, OAM was functionalized with FN by physical adsorption. The amount of FN adsorbed on the microspheres surfaces was characterized by a micro-BCA assay, resulting in an average concentration of $0.4 \pm 0.07 \mu \mathrm{g}$ FN per mg of microspheres.

Another reason to use this copolymer is its great versatility, as a variety of reactive co-monomers can be introduced into the formulation, which allows for engrafting biomolecules using different chemical reactions that can be adapted to the particularities of each substance. In this work AAc monomeric units are randomly dispersed along the copolymer chain to present carboxyl groups at the surface of the microspheres. Bae et al. in 1999 (98) performed the functionalization with Hep in polyurethane films through a carbodiimide reaction, and the engrafment of PEO with Hep. Following this method and with the incorporation of $\mathrm{COOH}$ groups onto the surface of the acrylate microspheres, it was possible to carry out the functionalization of both Hep and HS by the carbodiimide reaction.

As shown in Figure 6, the carboxyl groups of the 5AAc microspheres were activated by the incorporation of EDC, allowing for the formation of the intermediate oAcylisourea (Step 1.1), which can react with amine groups. However, as it is an unstable intermediate, NHS is added at the same time, which makes it possible to generate an amine-reactive NHS ester or stable active ester (Step 1.2). Then, with the addition of a primary amine from one of the chain ends of PEO, it interacts with the ester group allowing for the covalent binding of the carboxyl groups of the microsphere surface with the PEO molecule (Step 2). Once the PEO molecule is on the surface of the microspheres, we proceed to repeat steps 1.1 and 1.2, but in this case activating the carboxyl groups of Hep and HS (Step 3.1 and 3.2). After activation, the interaction between the primary amine group on the other extreme of the PEO with the amine-reactive NHS ester occurs 
(Step 4), producing the functionalization of the biomolecules on the surface of the microspheres through a covalent bond. The sub-products generated during the functionalization protocol are removed by washing as discussed in section 3.2.4. Finally, since some stable active ester located on the surface of the material could remain unreacted, and to avoid generating future interactions that could interfere during the development of the cell culture, these were inactivated using a high concentration of ETA (1M), changing the active ester into an inactive hydroxyethyl amide (Step 5) $(98,136)$. In this way, since the PEO molecule has a molecular weight $\sim 1,500 \mathrm{Da}$, the polysaccharide molecule is somewhat removed from the surface of the microsphere, gaining spatial mobility and the ability to adopt a natural conformation. The presence of Hep and HS on the surface of 5AAc microspheres were characterized by a GAG assay resulting in an average concentration of $6.8 \pm 0.6 \mu \mathrm{g}$ Hep per mg of microspheres and $1 \pm 0.3 \mu \mathrm{g}$ HS per mg of microspheres. 

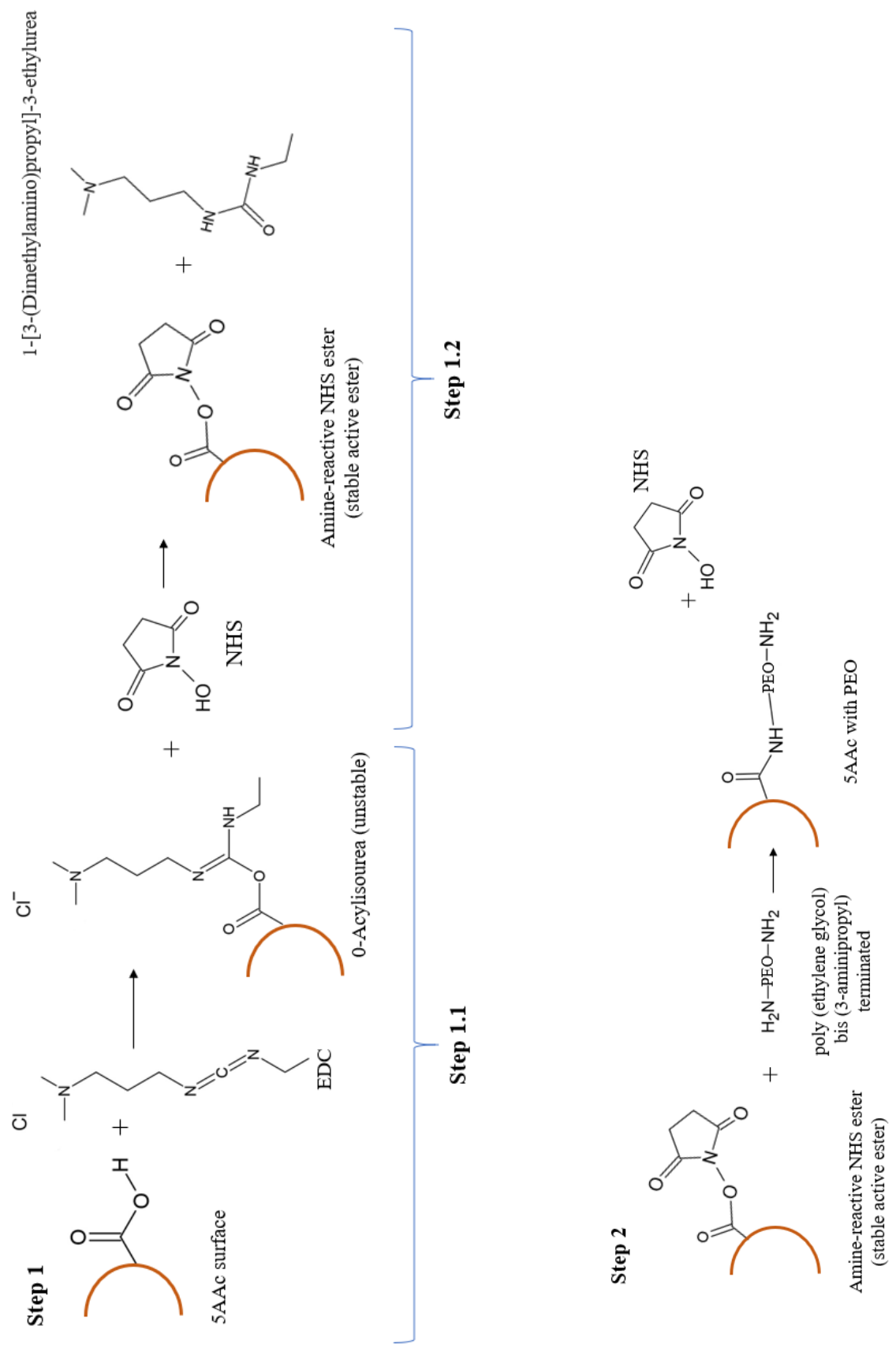


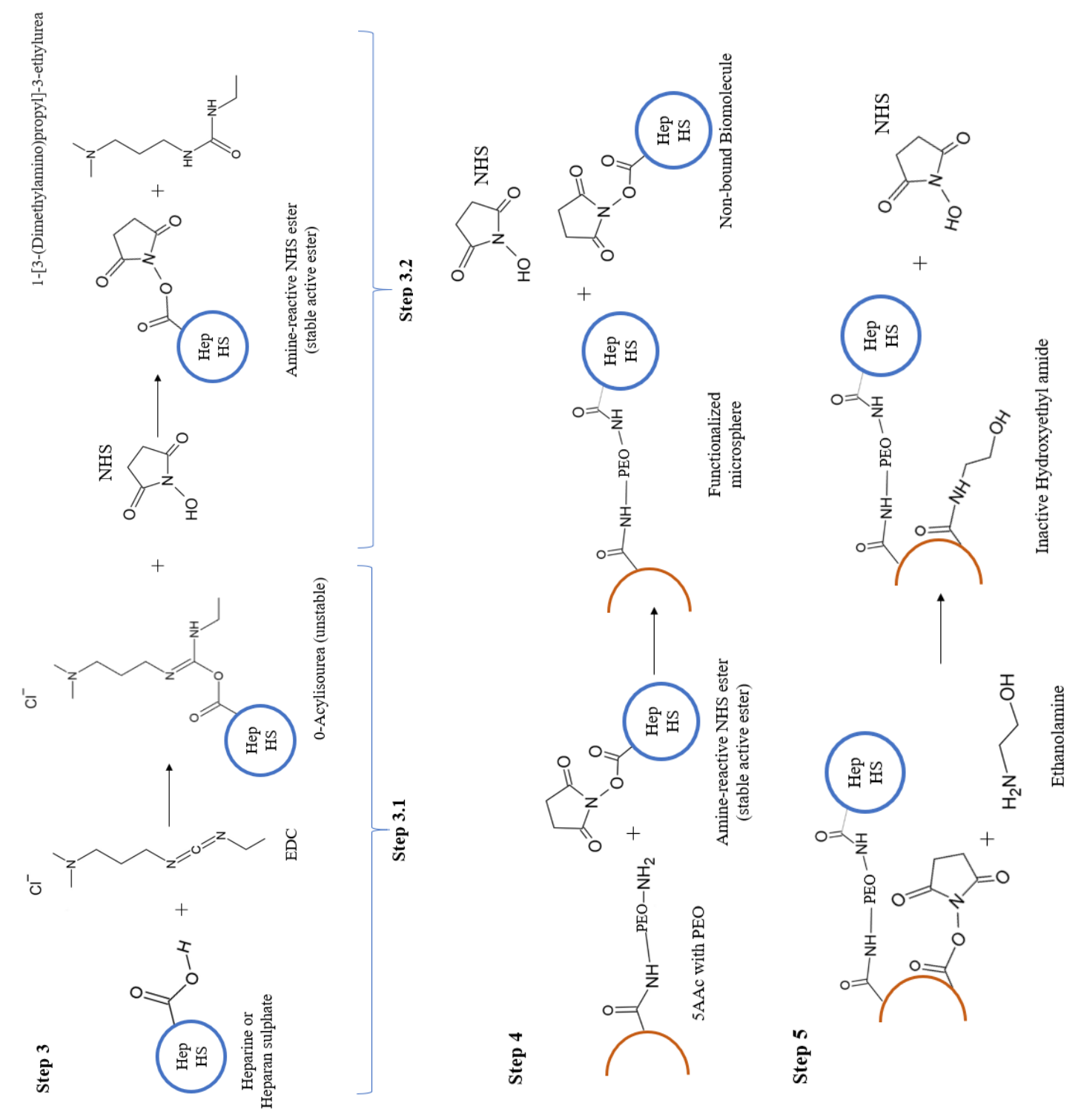

Figure 6. Chemical reactions during the functionalization of acrylic microspheres with 5\% of acrylic acid, heparin or heparan sulphate by the activation of their carboxyl groups through the carbodiimide reaction.

Regarding the physical characterization of the acrylic microspheres, the morphology of OAM could be observed in the FESEM images (Figure 7A and 7B). This technique did not show significant differences in surface topography due to the presence of the adsorbed FN, whose presence was nevertheless proven by the BCA assay. In the 
case of 5AAc microspheres, it was possible to observe through FESEM images no difference between OAM and 5AM (Figure 7A and C) and a certain change in the topography of the microspheres surfaces due to the grafted polysaccharide. Topography of the surfaces coated by HS or Hep (Figure 7D and 7E) was similar, showing rough structures with defined coated regions.

A

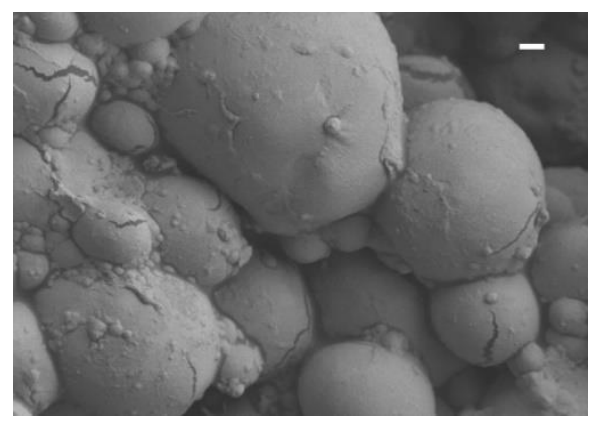

$\mathrm{C}$

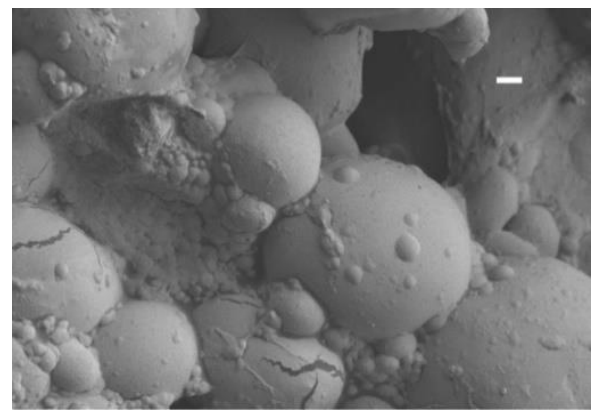

$\mathrm{E}$

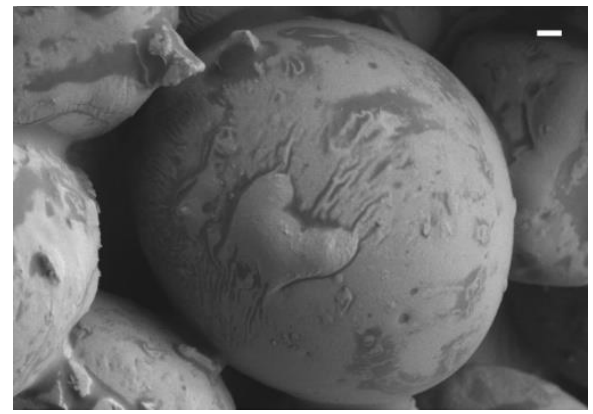

B

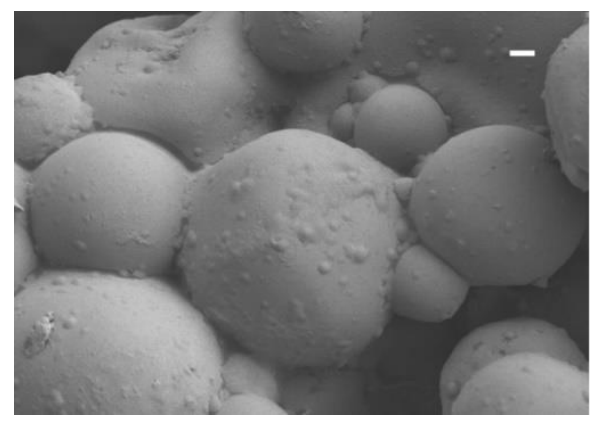

$\mathrm{D}$

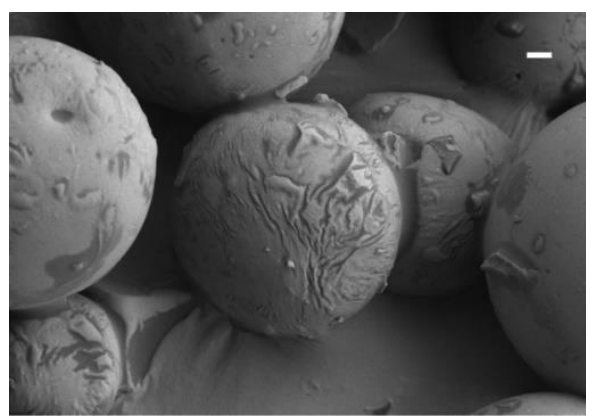

Figure 7. Surface morphology of acrylic microspheres studied by FESEM: A) Image of uncoated acrylic microspheres without acrylic acid (0AM), B) Image of acrylic microspheres without acrylic acid coated with fibronectin (MFN), C) Image of uncoated acrylic microspheres with 5\% of acrylic acid (5AM), D and E) corresponding respectively with acrylic microspheres with $5 \%$ of acrylic acid coated with heparan sulfate (MHS) and heparin (MHep) (bar: $1 \mu \mathrm{m})$. 
We tried to assess qualitatively by FTIR the presence of the $-\mathrm{COOH}$ groups at the microsphere's surface. However, the difference between 0AAc and 5AAc spectra was not significant because of the great chemical similarity between IR absorption of the carboxyl of AAc and the ester bonds of EA and EMA groups, as can be seen in the peaks at 1,159 and $1,018 \mathrm{~cm}^{-1}$ related to $\mathrm{C}-\mathrm{O}$ bending (Figure $8 \mathrm{~A}$ ) and a peak near $1,726 \mathrm{~cm}^{-1}$ attributed to carbonyl groups $(\mathrm{C}=\mathrm{O})$ (Figure $8 \mathrm{~B})(115)$. There was only a slight difference in the $810 \mathrm{~cm}^{-1}$ region (Figure $8 \mathrm{C}$ ) that could not be ascribed directly to the $-\mathrm{COOH}$ bond, and one might speculate that it could be related to conformational changes. In spite of this, quantification of the surface density of - $\mathrm{COO}$ groups was previously performed by Flores in 2016 in her Master Thesis (116) by a toluidine assay, obtaining a value of $0.75 \mathrm{nmol}$ $\mathrm{COOH}$ per mg of microspheres.

A

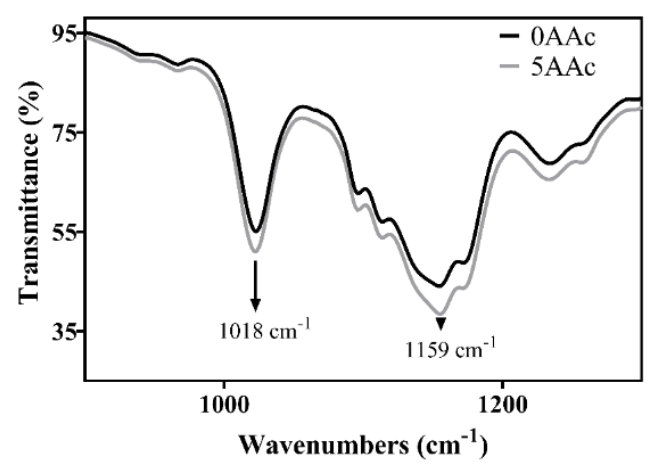

C

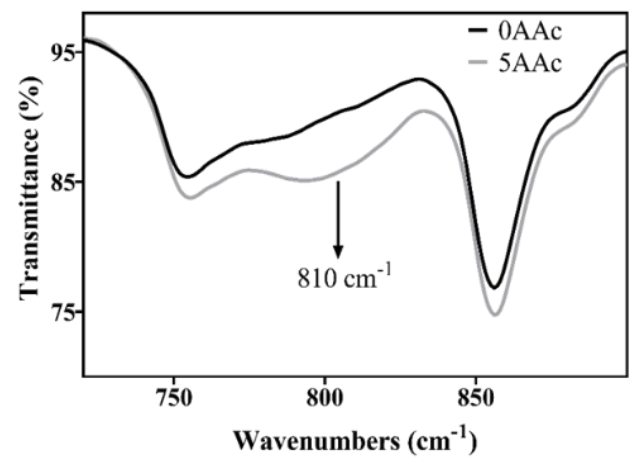

$\mathrm{B}$

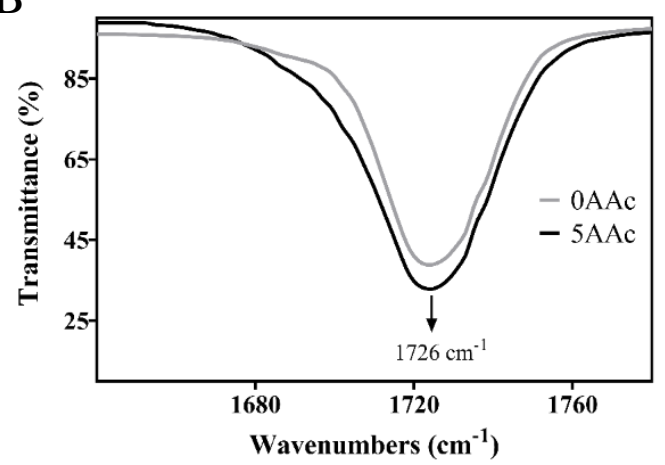

Figure 8. FTIR spectra of flat acrylic material without acrylic acid (0AAc) and flat acrylic material with $5 \%$ of acrylic acid (5AAc) with characteristics peaks at A) $900-1,300 \mathrm{~cm}^{-1}$, B) $1,640-1,780 \mathrm{~cm}^{-1}$ and C) $720-900 \mathrm{~cm}^{-1}$. 
One of the problems when working with microscale materials is usually related to their difficult manipulation. Particularly when the size of the cells and the microspheres is similar, the presence of the microgel during the processing of the samples can generate background interference or obstruction in certain equipment. These problems were solved in the acrylate microspheres by the incorporation of magnetic nanoparticles. The function of these nanoparticles was to facilitate the manipulation of the microspheres, since one can easily separate the microspheres from any aqueous suspension through the use of a neodymium magnet. This facilitates the manipulation of microspheres during the steps of functionalization, washing and sterilization, as well as being able to separate them from the cells after culture, allowing its analysis by FC or other techniques.

\subsubsection{Development and functionalization of microgels based on alginate microspheres}

The second system developed in this Thesis consisted in microgels formed by alginate microspheres. In this second line of work, it was intended that the microspheres themselves have the consistency of a hydrogel. Alginate microspheres were produced with a flow-focusing PDMS microfluidic device (Figure 3), in which the alginate solution is dispersed in the form of micro-drops in a liquid continuous phase of CHL. Gelification of the micro-drops is produced when they are immersed in an aqueous solution where calcium ions are present, resulting in microspheres with a high capacity for water absorption. The advantages of the microfluidic system for microsphere production comes from the laminar flow in which the micro-drops of the dispersed phase are formed, leading to a great control and narrow dispersion of particle diameters, and the ability to produce the required amount of particles in a relatively short time (117). This microfluidic system design has not been used before, with the continuous and dispersed phases as proposed in this work. For this reason, and because one of the most relevant parameters controlling microsphere size is the ratio between the flow rates of the dispersed and the continuous phases, a series of experiments was performed maintaining one of them constant while modifying the other one. In this way, a size diagram was developed for each of the conditions (Figure 9, 10 and 11). As can be seen in Table 1, as the flow of CHL increased, while maintaining a constant flow of alginate solution, smaller microsphere diameters 
were obtained, and in contrast, as the flow of alginate solution increased, maintaining a continuous flow of CHL, larger microsphere sizes were obtained (Table 2). Another parameter that depends exclusively on the alginate solution flow rate is the efficiency of the microspheres production. For this reason, an efficiency assay was performed at different alginate solution flows, observing a higher efficiency in microsphere production as the alginate flow increased (Table 3). In spite of the fact that with an alginate solution flow rate of $0.3 \mathrm{~mL} / \mathrm{min}$ the quantity of microspheres was more than double than with a flow rate of $0.13 \mathrm{~mL} / \mathrm{min}$, we used $0.13 \mathrm{~mL} / \mathrm{min}$ to obtain smaller microspheres.

Finally, it was decided to perform a final assay to further reduce the microsphere size using an alginate solution flow rate of $0.13 \mathrm{~mL} / \mathrm{min}$ and CHL flow rates of 5 and 6.2 $\mathrm{mL} / \mathrm{min}$. As seen in Figure 12, by increasing the continuous phase, it was possible to achieve average sizes below $200 \mu \mathrm{m}$ with a similar size distribution in both conditions, choosing as a final condition for cell culture the condition with an alginate solution flow rate of $0.13 \mathrm{~mL} / \mathrm{min}$ and a CHL flow rate of $6.2 \mathrm{~mL} / \mathrm{min}$, with an average microsphere size of $177 \pm 23 \mu \mathrm{m}$.

A

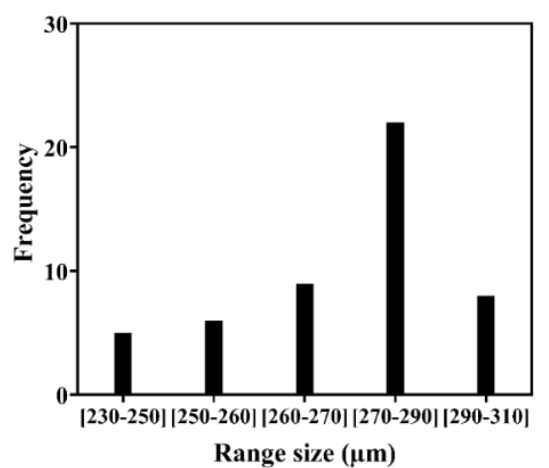

C

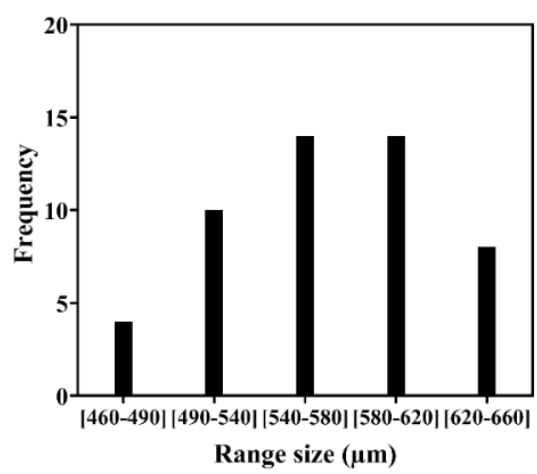

$\mathrm{B}$

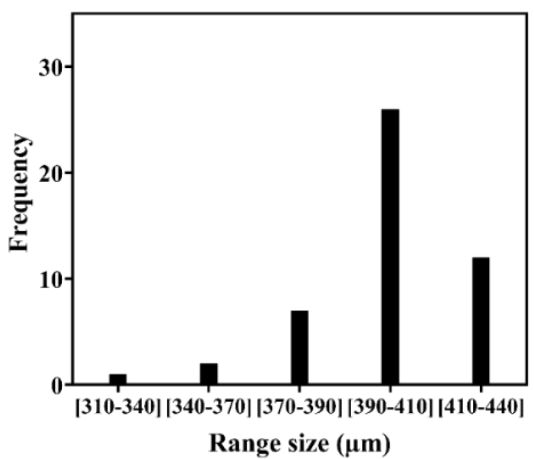

Figure 9. Alginate microsphere size distribution maintaining a constant flow rate of chloroform at 0.3 $\mathrm{mL} / \mathrm{min}$ and increasing the flow rate of alginate solution: A) $0.03 \mathrm{~mL} / \mathrm{min}$, B) $0.13 \mathrm{~mL} / \mathrm{min}$, C) $0.3 \mathrm{~mL} / \mathrm{min}$. 
A

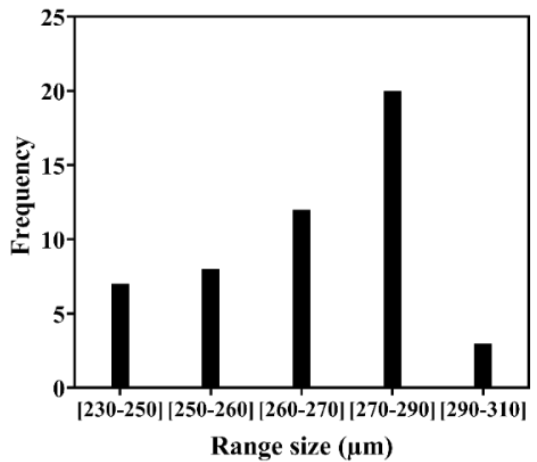

$\mathrm{C}$

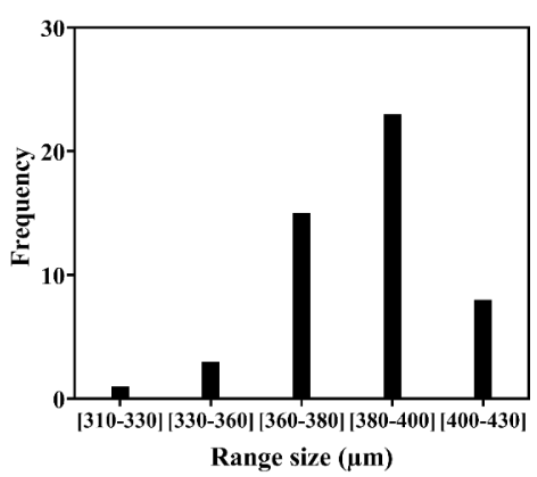

B

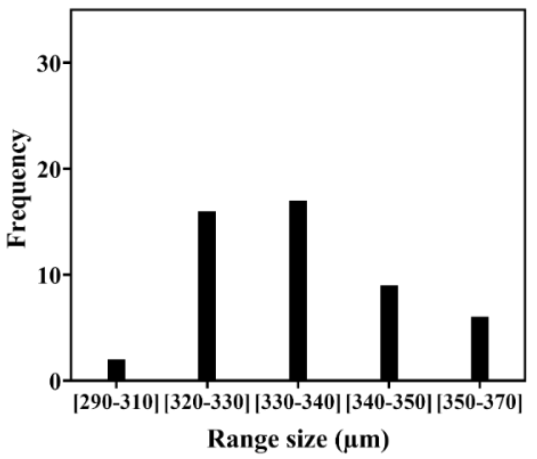

Figure 10. Alginate microsphere size distribution maintaining a constant flow rate of chloroform at 1.3 $\mathrm{mL} / \mathrm{min}$ and increasing the flo rate of alginate solution: A) $0.03 \mathrm{~mL} / \mathrm{min}$, B) $0.13 \mathrm{~mL} / \mathrm{min}$, C) $0.3 \mathrm{~mL} / \mathrm{min}$.

A

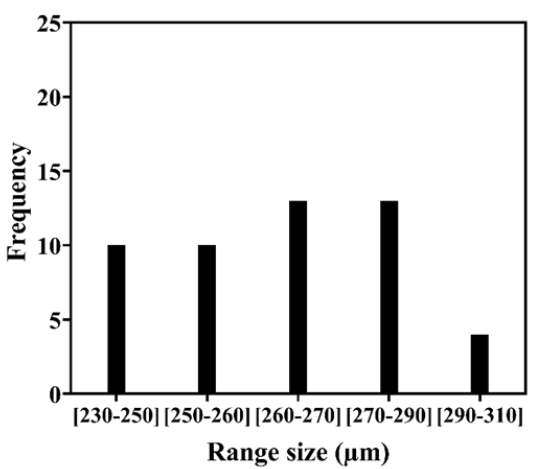

$\mathrm{C}$

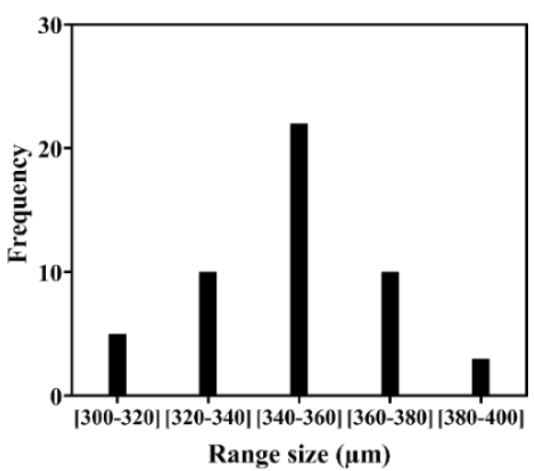

B

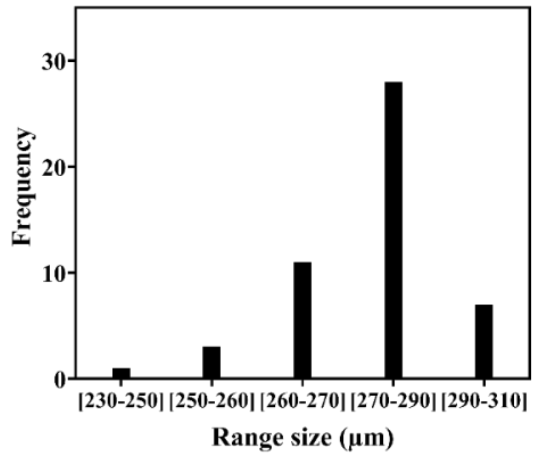

Figure 11. Alginate microsphere size distribution maintaining a constant flow rate of chloroform at 3 $\mathrm{mL} / \mathrm{min}$ and increasing the flow rate of alginate solution: A) $0.03 \mathrm{~mL} / \mathrm{min}$, B) $0.13 \mathrm{~mL} / \mathrm{min}$, C) $0.3 \mathrm{~mL} / \mathrm{min}$. 
Table 1. Average size of alginate microspheres by maintaining a constant flow rate of alginate solution and increasing the flow rate of the chloroform.

\begin{tabular}{|c|c|c|}
\hline Chloroform $(\mathrm{mL} / \mathrm{min})$ & Alginate solution $(\mathrm{mL} / \mathrm{min})$ & Average size $(\mu \mathrm{m})$ \\
\hline 0.3 & 0.03 & $273.4 \pm 16.9$ \\
\hline 1.3 & 0.03 & $268.4 \pm 14.9$ \\
\hline 3 & 0.03 & $264.2 \pm 17.7$ \\
\hline 0.3 & 0.13 & $399.2 \pm 22.1$ \\
\hline 1.3 & 0.13 & $333.8 \pm 14.6$ \\
\hline 3 & 0.13 & $276.6 \pm 12.7$ \\
\hline 0.3 & & $569.9 \pm 50.2$ \\
\hline 1.3 & 0.3 & $383.9 \pm 19.5$ \\
\hline 3 & 0.3 & $349.8 \pm 19.7$ \\
\hline
\end{tabular}

Table 2. Average size of alginate microspheres by maintaining a constant flow rate of chloroform and increasing the flow rate of alginate solution.

\begin{tabular}{|c|c|c|}
\hline Alginate solution $(\mathrm{mL} / \mathrm{min})$ & Chloroform $(\mathrm{mL} / \mathrm{min})$ & Average size $(\mu \mathrm{m})$ \\
\hline 0.03 & 0.3 & $273.4 \pm 16.8$ \\
\hline 0.13 & 0.3 & $399.2 \pm 22.1$ \\
\hline 0.3 & 0.3 & $569.9 \pm 50.2$ \\
\hline 0.03 & 1.3 & $268.4 \pm 14.9$ \\
\hline 0.13 & 1.3 & $333.8 \pm 14.6$ \\
\hline 0.3 & 1.3 & $383.9 \pm 19.5$ \\
\hline & 3 & $264.2 \pm 17.7$ \\
\hline 0.03 & 3 & $276.6 \pm 12.7$ \\
\hline 0.13 & 3 & $349.8 \pm 19.7$ \\
\hline 0.3 & 3 & \\
\hline & & \\
\hline & & \\
\hline
\end{tabular}


Table 3. Amount of microspheres produced during 5 minutes in each condition.

\begin{tabular}{|c|c|c|}
\hline Alginate solution (mL/min) & Chloroform (mL/min) & Efficiency (mg) \\
\hline 0.03 & 0.3 & $2.46 \pm 0.18$ \\
\hline 0.03 & 1.3 & $2.91 \pm 0.086$ \\
\hline 0.03 & 3 & $3.50 \pm 0.22$ \\
\hline 0.13 & 0.3 & $31.07 \pm 1.52$ \\
\hline 0.13 & 1.3 & $37.38 \pm 2.89$ \\
\hline 0.13 & 3 & $34.27 \pm 3.35$ \\
\hline 0.3 & & $87.21 \pm 1.3$ \\
\hline 0.3 & 0.3 & $90.33 \pm 1.06$ \\
\hline 0.3 & 1.3 & $94.97 \pm 0.90$ \\
\hline & 3 & \\
\hline
\end{tabular}

A

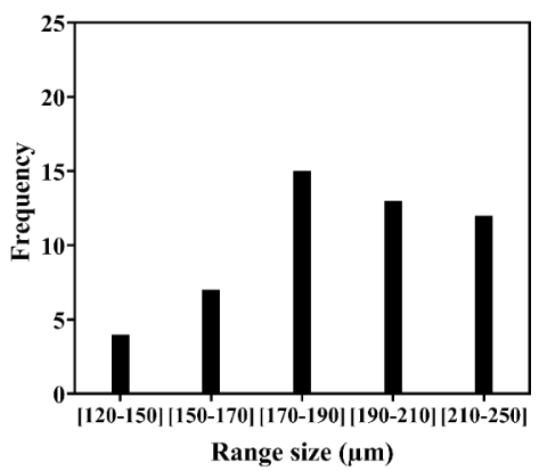

B

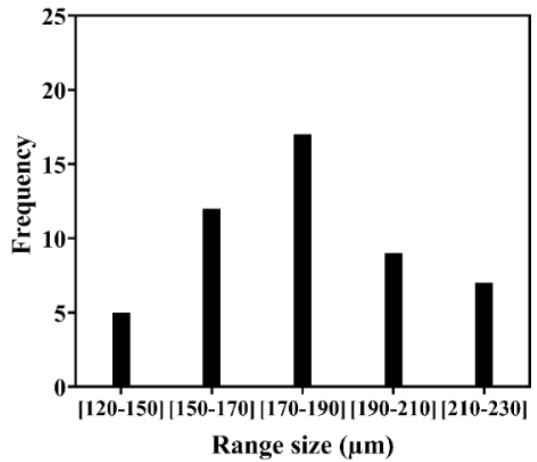

Figure 12. Alginate microsphere size distribution maintaining a constant flow rate of alginate solution at $0.13 \mathrm{~mL} / \mathrm{min}$ and increasing the flow rate of chloroform: A) $5 \mathrm{~mL} / \mathrm{min}$, B) $6.2 \mathrm{~mL} / \mathrm{min}$. 
The morphology of the microspheres produced can be seen in Figure 13. It should be noted that the observation of the hydrogel microspheres by FESEM has the difficulty of the contraction of the microspheres when dried, which can completely change their appearance. In this work, it was chosen to fix the microspheres by means of an additional crosslinking with a glutaraldehyde solution, followed by dehydration by immersion in ethanol/water solutions with increasing ethanol concentrations, to finish with a drying treatment in a supercritical fluid. This is how the images of Figure 13 were obtained. However, the fixation protocol with glutaraldehyde causes that the layers of COL and HA shed from the microspheres (Figure $13 \mathrm{~B}$ and C).

A

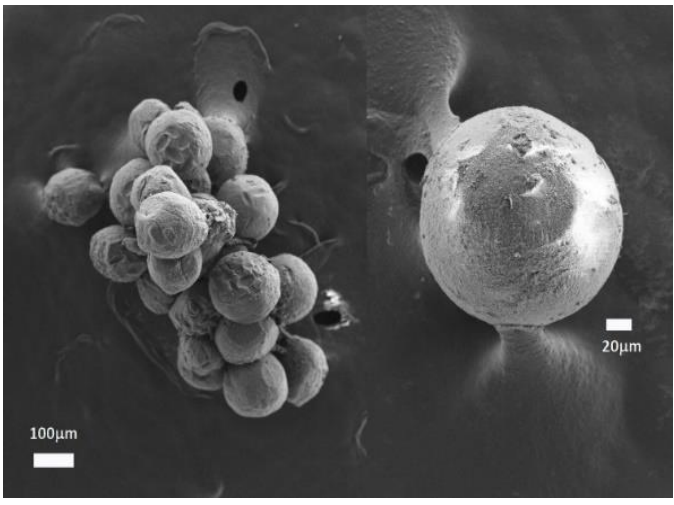

$\mathrm{C}$

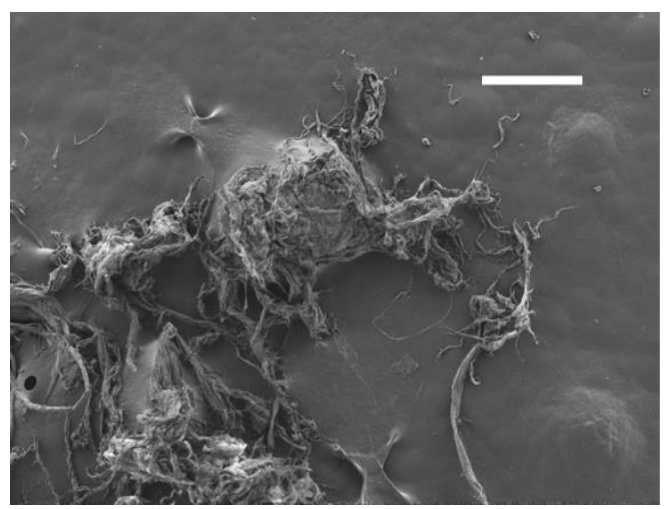

B

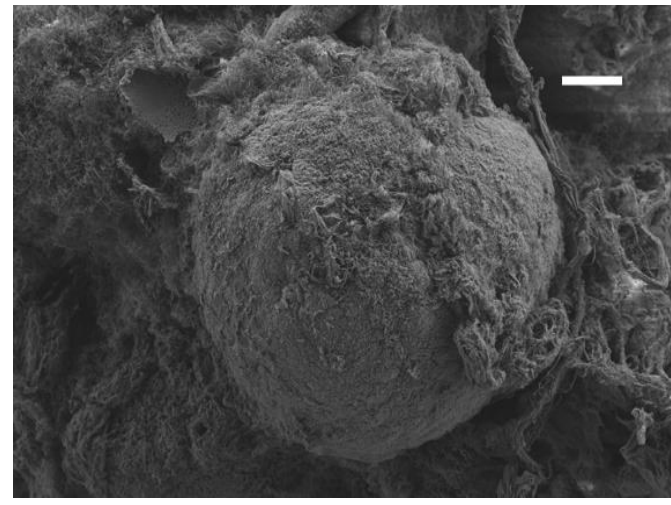

Figure 13. A) Uncoated alginate microspheres observed by FESEM after fixing with glutaraldehyde and drying with the critical point technique (left bar: $100 \mu \mathrm{m}$, right bar: $20 \mu \mathrm{m}$ ), B) Alginate microspheres coated with last layer of collagen type I (COLM) (bar: $20 \mu \mathrm{m})$, C) Alginate microspheres coated with last layer of hyaluronic acid (HAM) (bar: $200 \mu \mathrm{m})$. 
As for the method of functionalization, the LbL functionalization followed a protocol adapted from that proposed by Zhao et al. in 2014 (100), which coated films of poly (L-lactic acid) with COL and HA by electrostatic bonds. As the surface of the alginate is negatively charged at $\mathrm{pH}$, no further treatment was necessary to adhere to it a first layer of COL, which is charged positively at $\mathrm{pH}$, and from this first layer to incorporate HA and COL in successive layers. Since chemical reactions are not required, $\mathrm{LbL}$ is a fast and simple technique that can be easily extrapolated to the introduction of other biomolecules, because by acting on factors such as the $\mathrm{pH}$ of the solution, the presence of salts, temperature or other factors one can modulate the surface electrical charge for the formation of the coating with the appropriate counterion, providing a versatile platform to study a wide range of biomolecules such as Hep, HS, chondroitin sulphate, gelatin or other collagens. In this work, using COL and HA as alternate layers, two samples were prepared where one of them had 10 layers ending in HA and the other one 9 layers ending with COL. In order to confirm the coating protocol, a first experiment was performed by coating an alginate film's surface and assessing for the presence of COL and HA on the surface by FTIR. The spectra (Figure 14A and 14B) reveals the characteristic peaks of the three components of the system (alginate, HA and COL), since the infrared beam is capable of penetrating more than the thickness of the coating, which according to Götz et al. in 2020 (118), is expected to be $30 \mu \mathrm{m}$ with the implemented coating protocol. The FTIR spectrum of a wet alginate film is also shown for comparison. Figure 14A reveals the characteristic peaks of alginate, corresponding to the carbohydrate region in the interval of $870-1,200 \mathrm{~cm}^{-1}$, as well as the symmetric stretching band of the $\mathrm{COO}^{-}$group at $1,410 \mathrm{~cm}^{-1}(119,120)$. As for the COL peaks, the peak at $1,232 \mathrm{~cm}^{-1}$, corresponding to vibrations on the plane of amide III due to $\mathrm{C}-\mathrm{N}$ stretching and $\mathrm{N}-\mathrm{H}$ deformation, stands out, which in our case is shifted to slightly above $1,276 \mathrm{~cm}^{-1}$, perhaps due to the interactions of COL with HA and/or alginate (Figure 14A) (120,121). The same situation can be found in Figure 14B with respect to the characteristic peak at $2,925 \mathrm{~cm}^{-1}$, attributed to the stretching vibration of $\mathrm{C}-\mathrm{H}$ in both $\mathrm{HA}$ and $\mathrm{COL}$, that in the LbL surfaces splits into one peak at $2,840 \mathrm{~cm}^{-1}$ and another one at $2,917 \mathrm{~cm}^{-1}$, a fact that can be attributed to interactions between the two components $(122,123)$. Finally, in the case of HA, Figure 14A shows a peak at $1,315 \mathrm{~cm}^{-1}$ corresponding to $\mathrm{C}-\mathrm{H}$ vibration and a slight increase at $1,057 \mathrm{~cm}^{-1}$ for C-O stretching and vibration (124). 
A quantitative study was carried out to assess the increment of the total amount of $\mathrm{COL}$ in the coating with an increasing number of layers. Micro-BCA analysis showed that COL content increased continuously with the number of COL-HA bilayers (Figure 14C). Following the results shown in Figure 14C, the content of COL in the first layer adhered on the alginate surface was $6 \pm 1.6 \mu \mathrm{g} \mathrm{COL} / \mathrm{mg}$ microspheres. Subsequently, after the layer of HA (layer 2) was incorporated, the measured value of COL content was $6.3 \pm 0.5 \mu \mathrm{g} \mathrm{COL} / \mathrm{mg}$ microspheres, similar to the one observed in the first layer, which means that the HA layer did not hinder the quantification of COL present in the first layer. However, differences began to be observed with the incorporation of a second layer of COL (layer 3), with $9 \pm 1.3 \mu \mathrm{g} \mathrm{COL} / \mathrm{mg}$ microspheres. With the incorporation of the second layer of HA (layer 4 ), the observed value of COL content of $8.7 \pm 0.9 \mu \mathrm{g} \mathrm{COL} / \mathrm{mg}$ microspheres was slightly lower than that measured in the 3-layer sample. This behaviour is shown in the following bilayers (Figure 14C). Finally, with the incorporation of the fifth and final layer of COL (layer 9), values of $14.8 \pm 2 \mu \mathrm{g}$ COL/mg microspheres were reached. As shown by these results, in spite of the BCA test reactants being able to reach internal COL layers, HA layers somewhat hindered the diffusion through the coating so that the amount of protein was underestimated. Nevertheless, the continuous increase of the COL amount shown in Figure 14C proves the deposition of both COL and HA layers in the coating. A quantitative assessment of the amount of deposited HA was prevented by the chemical similarity with alginate. Moreover, because HA is the only type of GAG that is not sulfated (107), it was not possible to quantify it by the GAG assay because the dye, 1.9-dimethylmethylene, bound to sulfated GAGs such as Hep and HS. 
A

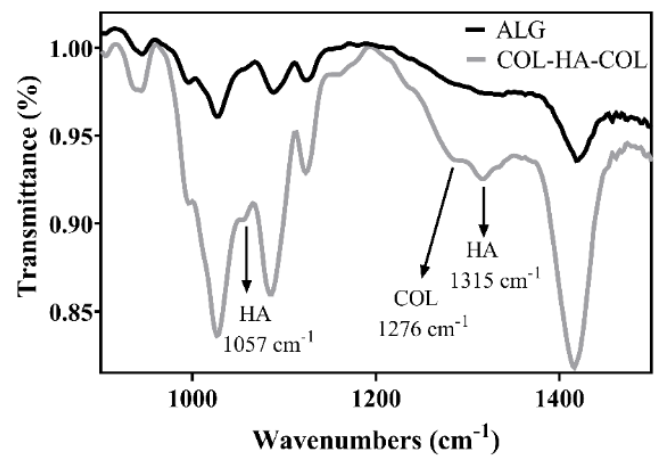

$\mathrm{C}$

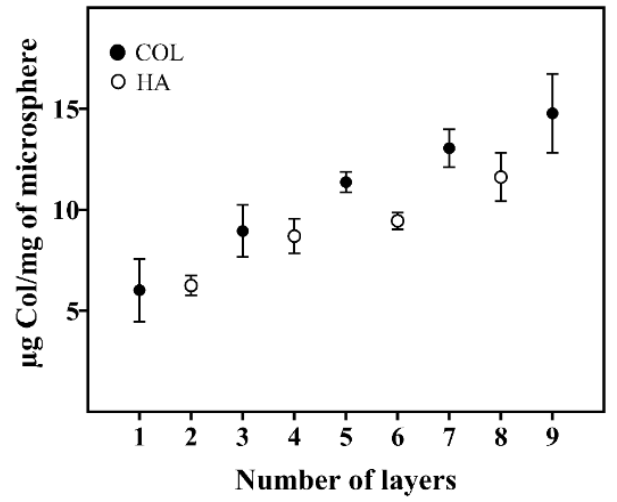

B

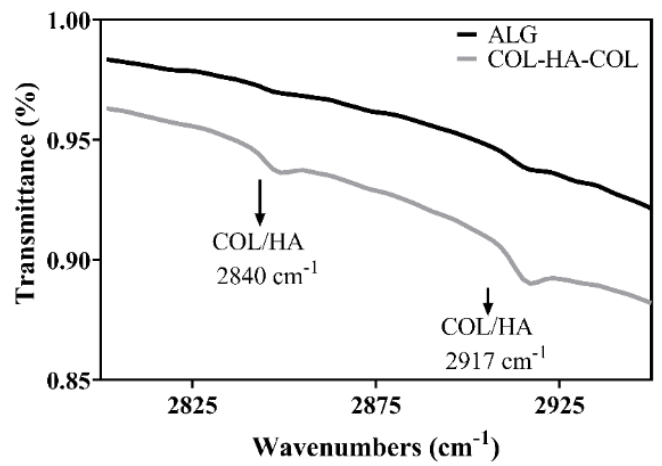

Figure 14. Characterization of alginate microspheres: A) and B) FTIR spectra of a flat uncoated alginate hydrogel (ALG) and a three-layer LbL coating (COL-HA-COL), C) COL content in the LbL coating by adding layers of COL and HA successively, as determined by micro-BCA. Graph show mean \pm standard deviation.

Previously, in section 4.1.1 the problems of working with microscale materials in relation to their handling have been discussed. In this case, since alginate microspheres do not have ferrite nanoparticles, the use of a neodymium magnet could not be used. However, since the size of the microspheres in this case of $177 \pm 23 \mu \mathrm{m}$ is much larger than the size of the mPCs, it was possible to separate the cells and the aqueous medium from the microspheres during the processes of functionalization, washing, sterilization and cell culture using a $70 \mu \mathrm{m}$ filter. Due to its size, the particles were collected using pipette tips whose ends were cut out to make them wider thus allowing the microspheres to be manipulated. 


\subsubsection{Concluding remarks related to the development and functionalization of different microgels}

Microgels able to incorporate different ECM components and present them during the cell culture were successfully produced with microspheres of varying size and composition. In this vein, we produced on the one hand acrylic microspheres with an average size of $9 \pm 4 \mu \mathrm{m}$ close to PCs size, and on the other hand bigger alginate microspheres with an average size of $177 \pm 23 \mu \mathrm{m}$. The different characteristics of these two types of microspheres allow for the design of different chemical routes for functionalization, adapted to the biomolecule of study, being able to apply already standardized functionalization protocols which would facilitate the coating of the microspheres. Therefore, for acrilyc microspheres, the implantation of Hep and HS through covalent bonds was possible by using a PEO bridge between the biomolecule and the surface of the material in the form of a flexible chain long enough to enable the biomolecule to acquire the natural conformation. In the case of $\mathrm{FN}$, taking advantage of the capacity of PEA to induce fibrillation by simple physical adsorption, FN was extended on the surface of the microsphere in the conformation that is expected to maximize the exposure of its cell adhesion domains. In the cases of COL and HA, their insertion on the alginate microsphere surface was carried out without the use of chemical reactions, varying only the $\mathrm{pH}$ of the solutions to carry out the functionalization through electrostatic links. In this way we obtained a great variety of artificial ECMs with biomolecules such as FN, Hep, HS, COL and HA, giving the system a great versatility to be able to implant a wider range of biomolecules in the future. Finally, by the quantitative and qualitative characterization of the biomolecules presented on the surface of the microspheres, it was possible to corroborate their functionalization and thus the generation of $3 \mathrm{D}$ environments that would mimic the in vivo ECM during cell cultures. 


\subsection{Evaluation of the cellular behaviour in a 3D culture environment based on functionalized microgel with extracellular matrix components}

The elaboration of a 3D cell culture platform was carried out to corroborate in a $\mathrm{BM}$ ECM mimetic environment the effect of the biomolecules in terms of cell cycle, viability, and proliferation of mPCs. Since each culture assay technique has its advantages and disadvantages, the proliferation results were corroborated using different techniques. One of them was the quantification of the total amount of DNA in each sample by the PicoGreen assay. Therefore, once the standard curve was made and the amount of DNA of the cell line used was known $(10.6 \pm 0.5 \mathrm{pg}$ per cell $)$, it was possible to determine the cell number in each sample, considering a greater cell number as an indicator of greater proliferation. FC is a technique with a high resolution which, due to its high sensitivity' has allowed for its consolidation as a routine clinical test in the diagnosis of MM (125). For the evaluation of cell proliferation, it was decided to use propidium iodide (PI) which binds to DNA and due to its stoichiometric nature allows for the separation of the DNA content of the cell cycle into 3 different stages: $G_{0}-G_{1}(2 n), S(2 n \sim 4 n)$, and $G_{2}-M(4 n)$ phases (126). Cells proliferate through a transition of $\mathrm{G}_{0}-\mathrm{G}_{1} \rightarrow \mathrm{S} \rightarrow \mathrm{G}_{2}-\mathrm{M}$. In the study of the expression of proliferation markers such as proliferating cell nuclear antigen (PCNA) and the nuclear protein $\mathrm{Ki}-67$, it was observed how their levels change during the cell cycle, with the highest levels of PCNA and Ki-67 in the $S$ and $\mathrm{G}_{2}-\mathrm{M}$ phase, respectively (127), considering as a proliferative stage the presence of cells located in S and G2-M cell cycle phases. One of the problems that can occur during the passage of samples through the FC is the formation of cell agglomerations that can lead to the generation of doublets of $\mathrm{G}_{0}-\mathrm{G}_{1}$ cells that are then interpreted as the $\mathrm{G}_{2}-\mathrm{M}$ peak (128). For this reason, the acquisition of the events was done at a low speed, to reduce the formation of agglomerates. Although the acquisition speed is low, doublets are still generated, which can be identified and removed in the software analysis by an area vs. width diagram of Forward Scatter Channel.

However, by reducing the speed of acquisition, the number of events that can be acquired is reduced, which directly affects the sensitivity of the technique such that a representative analysis may not be available. Because of this, in order to acquire as many events as possible (minimum $2 \times 10^{4}[126]$ ) and thus a better representation of the data, it 
was decided to pool the triplicates of each of the conditions into a single tube, which then went through the cytometer, acquiring a minimum number of $3.5 \times 10^{4}$ events per sample and a coefficient of variation $(\mathrm{CV})$ of less than $6 \%$. The equation, $\mathrm{CV}=$ standard deviation/mean channel number, is a quality parameter of the DNA histogram that is performed on $\mathrm{G}_{0}-\mathrm{G}_{1}$ peaks, with a $\mathrm{CV}$ value of less than $5-6 \%$ considered necessary for the valid interpretation of the data $(128,129)$. In this way, the use of both techniques makes it possible to corroborate whether the increase in cell number observed in the PicoGreen assay is associated with an increase in the percentage of cells in $\mathrm{S}_{-} \mathrm{G}_{2}-\mathrm{M}$ phase.

The evaluation of cell viability was carried out by FC to evaluate the percentage of apoptotic cells present in the sample. Apoptosis is the process by which cells undergo programmed structural and morphological alterations leading to cell death. In the early stages of apoptosis, cells lose their membrane phospholipid asymmetry through the translocation of the phosphatidylserine from the inner to the outer layer of the plasma membrane, where it can now be detected by the annexin- $\mathrm{V}$, which has a great affinity for phosphatidylserine, thereby identifying these annexin- $\mathrm{V}^{+}$cells as being in an early apoptosis. During the late stages of apoptosis, due to the progressive loss of the permeability membrane, apoptotic cells can be analysed by 7-aminoactinomycin D (7AAD) which selectively binds to GC regions of the DNA, thereby identifying cells that are both annexin- $\mathrm{V}^{+}$and $7-\mathrm{AAD}^{+}$as being in late apoptosis $(130,131)$. In this way, it is possible to analyse: viable cells (annexin- $\mathrm{V}^{-} / 7-\mathrm{AAD}^{-}$), early apoptotic (annexin- $\mathrm{V}^{+}$and 7-AAD ${ }^{-}$) and late apoptotic (annexin- $\mathrm{V}^{+}$and $7-\mathrm{AAD}^{+}$) cells. Cells are thus considered apoptotic in both early and late stages, requiring in the analysis a minimum of $6 \times 10^{4}$ events. The viability test allows us to verify the degree of cytotoxicity that could be generated by the microgel and/or the biomolecules under study. This technique also enables us to overcome the disadvantages of both techniques, since the PicoGreen assay has the disadvantage of only evaluating the total amount of DNA, including live and dead cells. Something similar occurs with cell cycle assays where the presence of dead cells can increase $\mathrm{G}_{0}-\mathrm{G}_{1}$ peaks. In this way, by having a viability control for each of the conditions and confirming a similar percentage of viability, it is possible to verify the results shown by both techniques.

One of the characteristics that must be considered when performing functionalization protocols is that the biomolecule remains stabilized on the surface of the material throughout the cell culture. Because of this, another factor taken into account when 
selecting functionalization methods was the stability of the biomolecule over time. Considering the 5AAc microspheres functionalized with Hep and HS, Bae et al. in 1999 (98) corroborated that the binding by covalent bonds obtained with the chemistry of carbodiimide and PEO graft maintains the Hep biomolecule stably on the surface of the material for 100 hours, being immersed throughout this time in PBS solution, which would correspond to a culture time of between 4-5 days. In the case of 0AAc, previous work by our group (99) demonstrated that cell-FN adhesion, by the functionalization of 0AAc microspheres with FN by physical adsorption, is maintained through 7 days of cell culture. For the stability of electrostatic bonds between different layers of HA and COL in alginate microspheres, Zhao et al. in 2014 (100) showed that the LbL technique allows for the retention of both biomolecules on the surface of the material at culture times of 67 days up to 14 days. This biostability is of great importance, since, in the design of the artificial 3D environment to perform the cell cultures, the way in which the ECM components are introduced into the culture medium plays an important role, so that, despite the changes in the liquid medium required to supply the necessary nutrients to the cells and to eliminate the waste products of cell metabolism, the ECM components remain available to the cells throughout the entire culture time. For this reason, since the ECM components are located on the surface of the microspheres, an important step during cell cultivation was the changes of medium. The culture environment is a dynamic system with a volume of $500 \mu \mathrm{L}$, of which approximately $100 \mu \mathrm{L}$ correspond to the microgel and $400 \mu \mathrm{L}$ to the cell culture medium. The change of medium was made by adding $400 \mu \mathrm{L}$ of fresh culture medium, resulting in a final volume of $900 \mu \mathrm{L}$. Once the fresh culture medium was added, the culture was again shaken for 15 minutes to homogenize and distribute the new nutrients. Then, for both the alginate and acrylate microgels, the orbital agitation was stopped for 1 hour, enough time for the cells and the microgels to precipitate to the bottom of the well. Once precipitated, in order not to alter the microgel-to-liquid ratio, $400 \mu \mathrm{L}$ of liquid medium was carefully removed and the culture well again shaken. Since the change of culture medium is partial, instead of changing the liquid culture medium after 2-3 days as in a conventional 2D culture, it was decided to do it daily.

Due to the novelty of our platform, it was not known if the interaction between ECM components on the surface of the material with mPCs would occur. For that reason, to validate the interaction, it was decided to use biomolecules whose interaction with the RPMI 8226 cell line has been well studied in 2D cultures, as in the cases of FN and HA 
$(28,64)$. Then, biomolecules whose interaction with mPCs is less well-known as in the cases of Hep, HS or COL were used to elucidate with our platform the cellular response generated by each biomolecule.

\subsubsection{Influence of volume fraction of acrylic microspheres on cell proliferation}

One of the relevant parameters in the design of the $3 \mathrm{D}$ environment is the volume fraction occupied by the microspheres, which is expected to influence cell-material average distance and the dynamics of the system under stirring. This feature is also important for other 3D culture systems, as discussed above in Sections 1.5 and 1.6 (132). The first experiment was performed to assess whether the solid fraction in the microgel affects cell proliferation. It is difficult to directly measure the volume of microspheres added, thus volume occupied by the biomaterial was determined by weighing, considering that the density of the copolymer in bulk is $1.16 \mathrm{mg} / \mu \mathrm{L}$. Microgels containing $100,80,60$ and $40 \mathrm{mg}$ of $0 \mathrm{AM}$ were prepared in which the volumes of the microspheres were $86.20,68.96,51.72$ and $34.48 \mu \mathrm{L}$, respectively. As the final volume of each well was $500 \mu \mathrm{L}$, we had microsphere/liquid-medium percent volumes of 17.2, 13.8, 10.34 and $6.89 \% \mathrm{v} / \mathrm{v}$, respectively. In this way, in conjunction with an orbital shaking, the microspheres were suspended homogeneously in the medium (Figure 15A). Cell culture was performed, evaluating the cell proliferation with a PicoGreen assay performed on days 2, 5 and 7 using 0AM microgels, with the microsphere volume fraction specified above and seeding $5 \times 10^{4}$ cells per well. On day 2 , differences in cell proliferation among the different microsphere volume ratios were not yet statistically significant, but it was possible to see a small increase in the cell number in the 0AM conditions as compared to SUSP control (Figure 15B). However, on day 5 a higher cell proliferation was observed in microgel conditions with respect to SUSP control, which was statistically significant (Figure 15B). Among all the conditions, the M13 condition was the most remarkable, with a difference of $2.52 \times 10^{5} \pm 2.49 \times 10^{4}$ cells with respect to the SUSP condition. To corroborate that cell death was not interfering with the PicoGreen analysis, a viability assay was performed, obtaining a cell viability of around $88.9 \pm 1.9 \%$ under all conditions (Figure 15C). We attributed this proliferation effect to the 3D microgel configuration 
platform, in which the microspheres suspended in the liquid medium performed as a scaffolding system and the excluded volume due to the microspheres had the effect of increasing cell-cell contact. Moreover, due to the dynamic conditions of the culture, the mobility of the microspheres avoided the restrictions imposed when the cells are cultured in the pores of a scaffold or in a conventional hydrogel, where the cells are confined. This provides greater freedom for the cells to expand and proliferate. Moreover, at day 7 of cell culture it was observed that all the microgel conditions presented a similar number of cells, indicating that the platform had reached its saturation level due to the high growth rate of this cell line, discarding by viability assay the possibility that the saturation increased cell mortality.

A

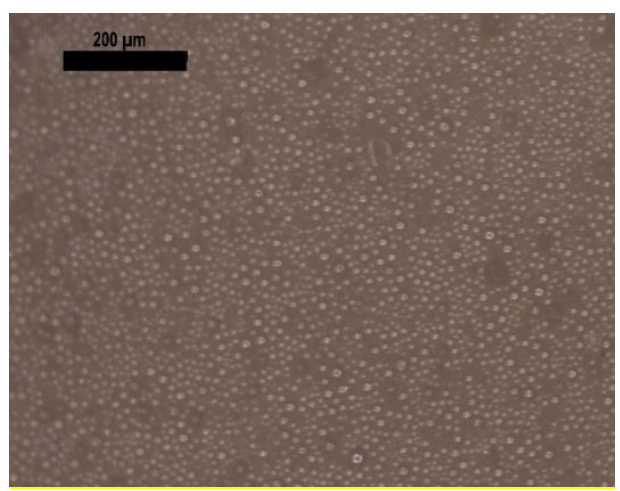

$\mathrm{C}$

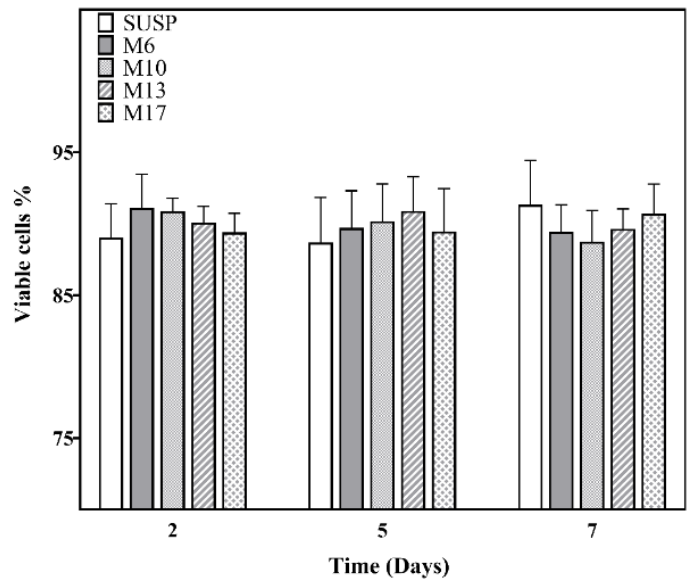

B

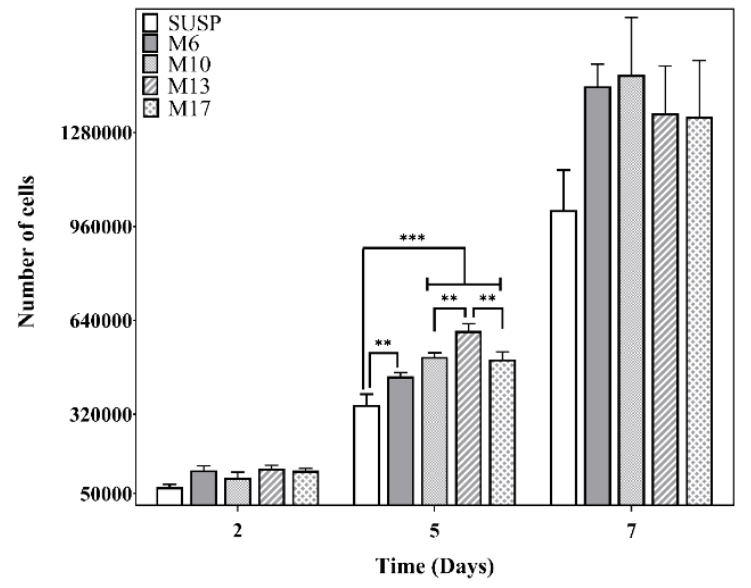

Figure 15. A) Optical microscopy image (20x) of the dispersion of $13.8 \% \mathrm{v} / \mathrm{v}$ acrylate microgel in a $\mathrm{P} 24$ well. B) Evaluation of cell proliferation, and C) Cell viability at different volume ratios of 0AM-to-liquid medium at 2, 5 and 7 days. OAM: uncoated acrylic microspheres without acrylic acid. SUSP: suspension culture without microspheres, M17: $17.2 \% \mathrm{v} / \mathrm{v}$ of microspheres, M13: 13.8\% v/v of microspheres, M10: $10.34 \% \mathrm{v} / \mathrm{v}$ of microspheres, M6: $6.89 \% \mathrm{v} / \mathrm{v}$ of microspheres. Graphs show mean \pm standard deviation. The level of statistical significance is shown by the following legend: $(* *) p$-value $\leq 0.01,(* * *) p$-value $\leq 0.001$. 
According to these results, a 3D culture platform based on OAM improves the proliferation of mPCs in a dynamic condition as compared to a suspension state without microgel. Considering that one of the in vivo characteristics of tumoral cells is their high proliferation, the M13 condition that provided higher proliferation than the other microsphere volume fractions was selected for the future assays, in order to have an in vitro model as close as possible to the in vivo one.

\subsubsection{Influence of volume fraction of alginate microspheres on cell proliferation in an environment with the presence of hyaluronic acid and/or collagen type I}

As for the biomolecules to study in this assay, it is worth mentioning that hardly any studies have been published on the influence of COL on the growth or generation of DR in MM. Cell adhesion to COL is mediated by syndecan-1 (72). The involvement of HA on the RPMI 8226 cell line has been shown to be associated with the generation of $\mathrm{DR}$, produced by upregulation of bcl-2 and the increase of NF- $\kappa \mathrm{B}$ activity (64). As reviewed above in sections $1.2,1.3$ and 1.4 , both bcl- 2 and the activity of NF- $\kappa B$ promote growth, survival, and DR of MM $(10,26)$. Therefore, following the literature it is possible to set up a hypothesis in which HA is not only involved in the generation of DR but also may favour cell proliferation. For this reason, it was decided to carry out a first experiment to test the hypothesis that HA promotes proliferation, and on the other hand to elucidate a little more the involvement of COL with regards to cell proliferation. It can be highlighted that the main difference between our research and previous studies $(64,72)$ is that the involvement of HA on the RPMI 8226 cell line was performed by Vincent et al. in 2003 (64) in a conventional 2D culture incorporating the dissolved biomolecule in the culture medium, while the COL (72) was attached to the bottom of the well. In our case, both biomolecules are bound to the surface of alginate microspheres through electrostatic bonds (Figure 16), in a three-dimensional suspension environment, keeping the biomolecules in the proximity of the cells. 


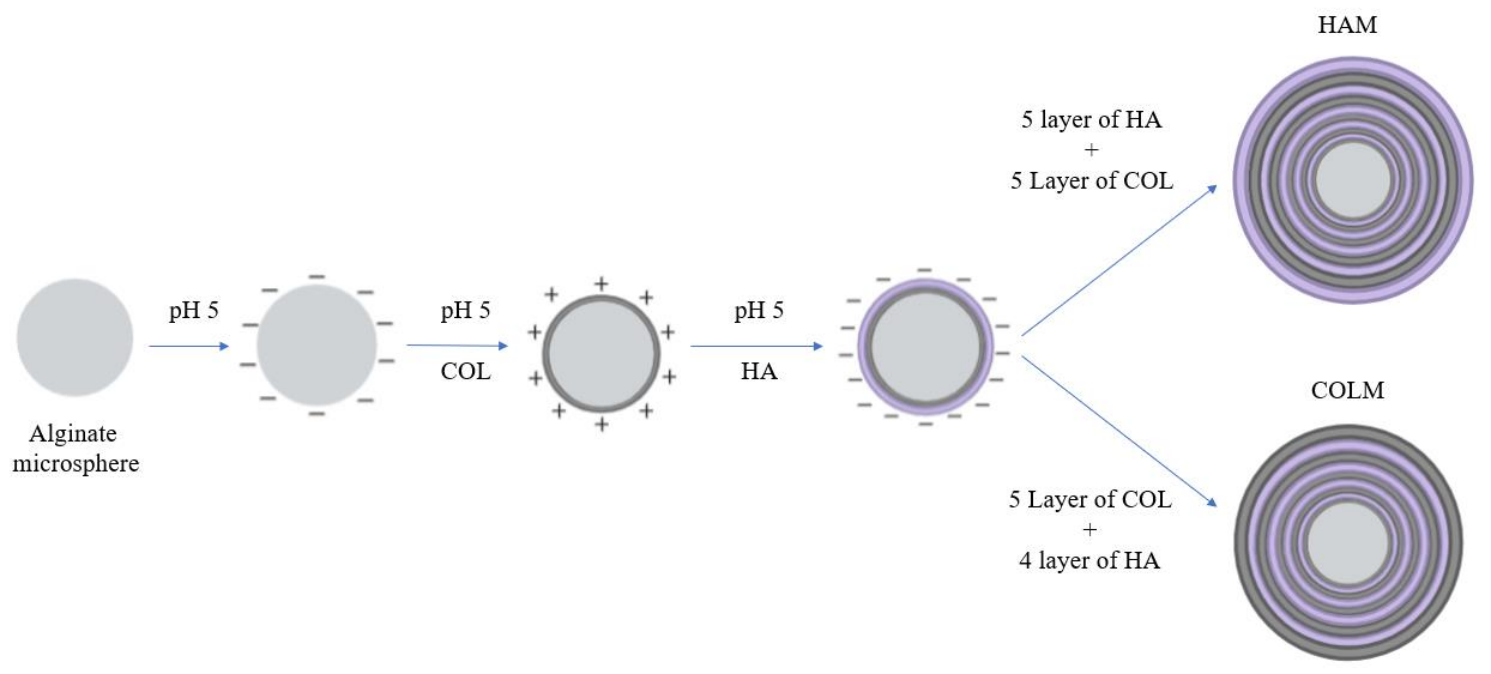

Figure 16. Schematic representation of the functionalization of alginate microspheres with COL and HA through the formation of electrostatic bonds in the technique known as layer-by-layer. COL: collagen type I, HA: hyaluronic acid, HAM: alginate microspheres with a last layer of hyaluronic acid, COLM: alginate microspheres with a last layer of collagen type I.

Following the results obtained in Section 4.2.1, where it was observed that the ratios of microspheres/liquid-medium corresponding to between $13.8-17.2 \% \mathrm{v} / \mathrm{v}$, cells proliferate more than in suspension culture, it was decided to use from the beginning a volume ratio of $20 \% \mathrm{v} / \mathrm{v}$. Since the alginate density is $1 \mathrm{mg} / \mathrm{mL}$ and their manipulation is more difficult than that of acrylic microspheres, the alginate microgel were added using a volumetric value instead of weighing it as in the case of the acrylate microspheres discussed in section 4.2.1, incorporating $100 \mu \mathrm{L}$ of wet alginate microspheres and $400 \mu \mathrm{L}$ of liquid medium. Once the concentration of the microgel was established, the influence of HA and COL on cell proliferation was assessed by cell cycle assay, and the cell numbers measured by the total DNA content in PicoGreen assay at days 2, 5 and 7 . Also, a viability assay was performed. $1.5 \times 10^{5}$ of cells were used for the seeding at every test. The cell cycle of cells cultured in AGM and COLM conditions showed a small and unremarkable decrease in the fraction of cells arrested in the $G_{0}-G_{1}$ phase on day 2 and 5 as compared to the SUSP condition (Figure 17A). This is also responsible for the slight increase in cell number observed on day 5 (Figure 17B), this increase being approximately $2.15 \times 10^{5} \pm 1.16 \times 10^{5}$ and $1.56 \times 10^{5} \pm 7.4 \times 10^{4}$ cells for AGM and COLM, respectively, as compared to SUSP. These slight differences, in spite of not reaching 
statistical significance, could be similar to the effect observed in Section 4.2.1, in which cell culture in a microgel environment favoured cell proliferation through the improvement of cell-cell contact. Consequently, as the results with COLM are very similar to those of the AGM, it can be deduced that the presence of COL does not alter the proliferative capacity of the mPCs. However, the presence of microgels when the last layer is HA yields an improvement in cell proliferation. In the cell cycle assay, a clear decrease in the fraction of cells arrested in $\mathrm{G}_{0}-\mathrm{G}_{1}$ phase between HAM and MIX conditions was observed with respect to SUSP, AGM and COLM (Figure 17A). This effect was corroborated by the PicoGreen results, in which, although on day 2 of cell culture only a slight increase in cell number was observed, this difference was significant on day 5 of the culture. The cell number in HAM and MIX conditions was $5.79 \times 10^{5} \pm$ $1.2 \times 10^{5}$ and $5.92 \times 10^{5} \pm 1.05 \times 10^{5}$ cells, respectively, higher than in the SUSP condition, $3.64 \times 10^{5}$ and $3.76 \times 10^{5}$ cells, respectively, higher than in AGM condition, and $4.19 \times 10^{5}$ and $4.32 \times 10^{5}$ cells, respectively, higher than in the COLM condition (Figure 17B). Since the cells number between HAM and MIX condition is very similar, and we do not expect that COL contribute to induce cell proliferation as we discussed above, we can deduce that the amount of HA contained in the sample with $50 \%$ of HAM is enough to generate the proliferative effect. In this way, the use of both techniques allowed for the corroboration that the presence of HA promotes cell proliferation and, in contrast, the presence of COL does not. The effect of HA on mPCs cell proliferation was studied by Vincent et al. in 2001 (65), showing in a 2D culture that HA promotes cell proliferation in human IL-6 dependent cell lines through an IL-6-mediated pathway involving the phosphorylation of retinoblastoma proteins. In our case, by employing an IL-6independent cell line our results suggest that the mechanism of HA in the promotion of mPCs proliferation acts through different signaling pathways in the IL-6-dependent MM cell line and the RPMI 8226 IL-6-independent cells. This fact is not surprising, since, within the same MM cell line it was observed that the DR induced by HA to DEX is mediated through distinct signaling pathways in IL-6-independent and IL-6-dependent MM cell lines (64).

As for day 7 of the culture, it is possible to see how the cell number in each condition was very similar and not statistically different (Figure 17B). This is a clear indication that the platform had reached its saturation level due to the high growth rate of this cell line as shown in Section 4.2.1. Looking at the viability results (Figure 17C), it can be observed 
that even when the culture was saturated with cells there was no increase in cell mortality, with each condition maintaining at day 7 an average viability close to $91 \pm 2.3 \%$. These data are relevant since, as shown in Figure 17B, the increment in the number of cells at day 7 was much smaller than would be expected from the evolution between day 2 and day 5 under all conditions, being more remarkable in the HAM and MIX conditions. Therefore, it can be discarded that this reduction in proliferation was as a result of the presence of dead cells. Following the incorporation of a cell cycle assay, in contrast to section 4.2.1, it can be observed that on day 7 of culture, as compared to day 5, there was an increase in the percentage of cells arrested in $\mathrm{G}_{0}-\mathrm{G}_{1}$ phase under each of the conditions, these being differences of 5\% compared to the SUSP condition, 9.4\% compared to AGM and $8.1 \%$ compared to COLM (Figure 17A). This increase was remarkable under the HAM and MIX conditions, being of $15.9 \%$ and 14.9\%, respectively (Figure 17A). The increase in the percentage of cells in the $\mathrm{G}_{0}-\mathrm{G}_{1}$ phase due to the culture saturation means that the cells were maintained in a quiescent state because of nutrient deficiencies, which could explain why the number of cells was smaller than expected at day 7 , as observed in Figure 17B and Figure 15B. 
A

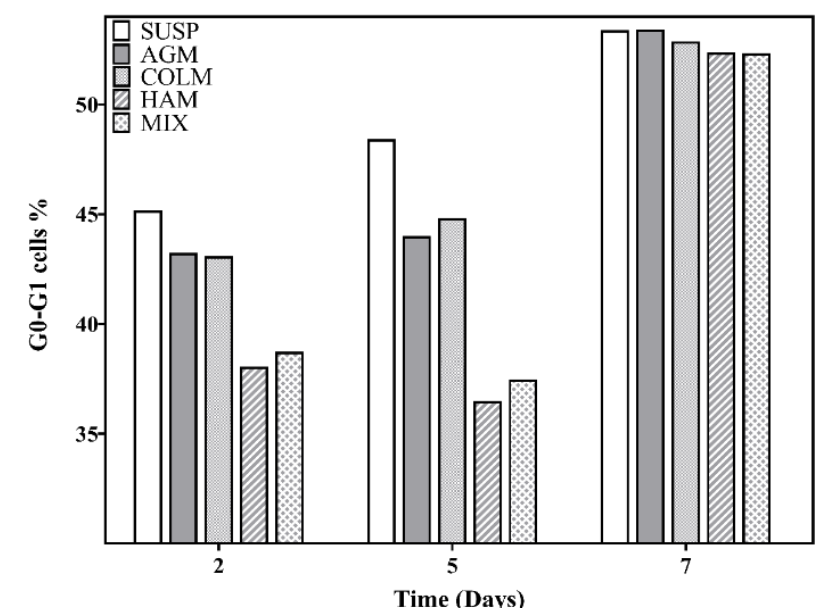

$\mathrm{B}$

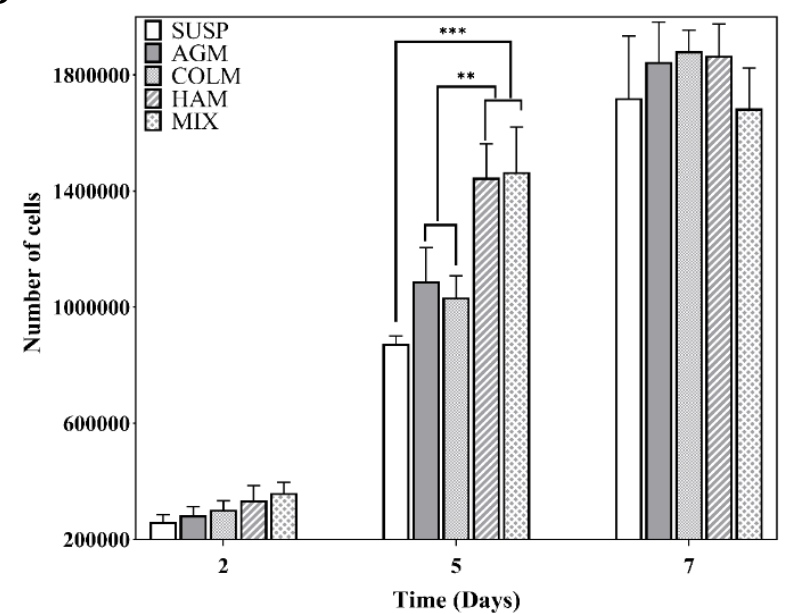

$\mathrm{C}$

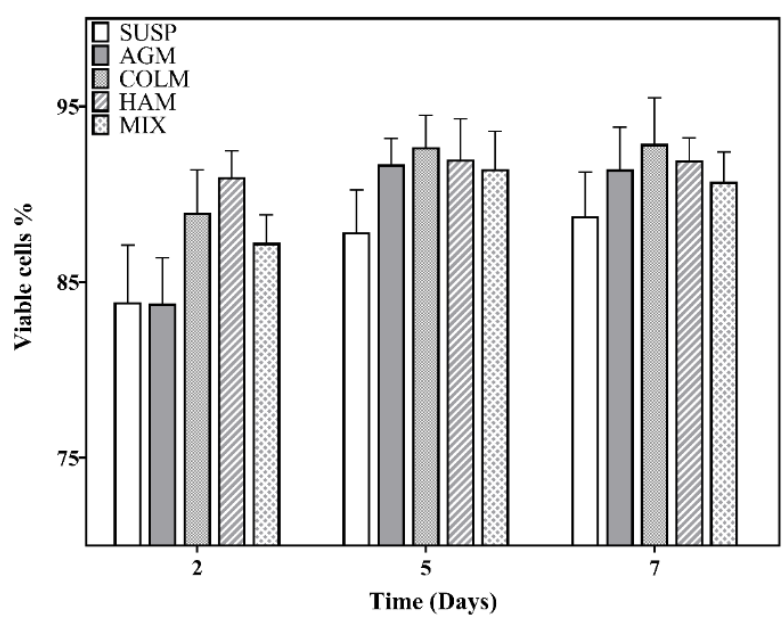

Figure 17. Results of cell growth and viability in alginate microgel. A) Fraction of cells in G0-G1 phase. B) Cell number under different culture conditions. C) Percentage of viable cells. Graphs show mean \pm standard deviation. SUSP: suspension culture without microspheres, AGM: uncoated alginate microspheres, COLM: alginate microspheres coated with last layer of collagen type I, HAM: alginate microspheres coated with last layer of HA, MIX: microgel consisting of 50\% of HAM and 50\% of COLM. The level of statistical significance is shown by the following legend: $(* *) p$-value $\leq 0.01,(* * *) p$-value $\leq$ 0.001 . 


\subsubsection{Influence of cell adhesion to fibronectin on cell cycle}

The adhesion of the mPCs to FN is one of the most researched interactions in MM, which has shown it to be mediated by VLA-4 integrin resulting in the arrest of cells in the $\mathrm{G}_{0}-\mathrm{G}_{1}$ phase of the cell cycle $(28,62)$. It is worth mentioning that these studies have been carried out using conventional $2 \mathrm{D}$ cultures with FN adhered to the bottom of the well, which is an unrepresentative model of the in vivo environment. For this reason, our 3D model with the development of PEA microspheres capable of reproducing fibrillogenesis of FN produced in vivo is intended to be a more reliable model than $2 \mathrm{D}$ cultures. Since FBS contains other proteins that can be adsorbed on the surface of the biomaterial, to avoid interfering in any way with the mPCs-MFN binding, cells were incubated with MFN for 1 hour without agitation and without FBS, and then FBS was added for the rest of the culture. As it is a suspension culture it is necessary to determine through the block of the cells in $\mathrm{G}_{0}-\mathrm{G}_{1}$ phase if the adhesion is being carried out. Because of this, a cell cycle assay was performed. $1.5 \times 10^{5}$ cells were grown at days 2,3 and 5 . On day 2, the MFN state presented a higher arrest in the $\mathrm{G}_{0}-\mathrm{G}_{1}$ phase compared to the rest of the conditions, with a difference of $18 \%$ with respect to SUSP and $23 \%$ with respect to $0 \mathrm{AM}$. At day 3 these differences were reduced to approximately $10 \%$ with respect to the SUSP and 16\% with respect to OAM. Finally, on day 5 there was a difference of $7 \%$ with respect to SUSP and $10 \%$ with respect to $0 A M$. This decrease of $\mathrm{G}_{0}-\mathrm{G}_{1}$ phase arrest over time may be due to the proliferation of non-attached cells, which reduces the percentage of those arrested in $\mathrm{G}_{0}-\mathrm{G}_{1}$ phase. We can thus conclude that the adhesion between mPCsMFN induces the arrest of the cells in $\mathrm{G}_{0}-\mathrm{G}_{1}$ phase. Regarding the SUSP and OAM conditions, it can be observed how the SUSP condition presents a higher percentage of cells in phase $\mathrm{G}_{0}-\mathrm{G}_{1}$ than the $0 \mathrm{AM}$ condition at the three culture times (Figure 18A), confirming the results observed with PicoGreen (Figure 15B) where the presence of the microgel favours cell proliferation. Also, all the conditions present a cell viability of around $89.8 \pm 2.5 \%$ (Figure $18 \mathrm{~B}$ ), corroborating the non-cytotoxicity of the acrylate material. 
A

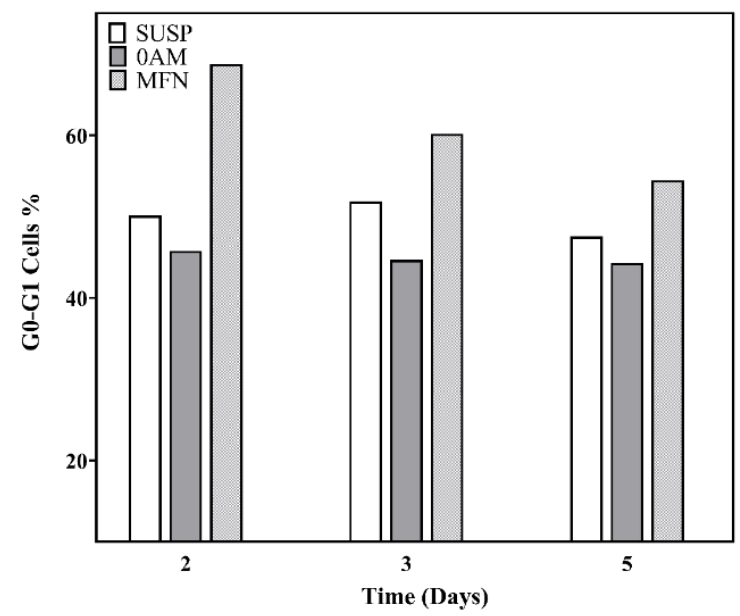

B

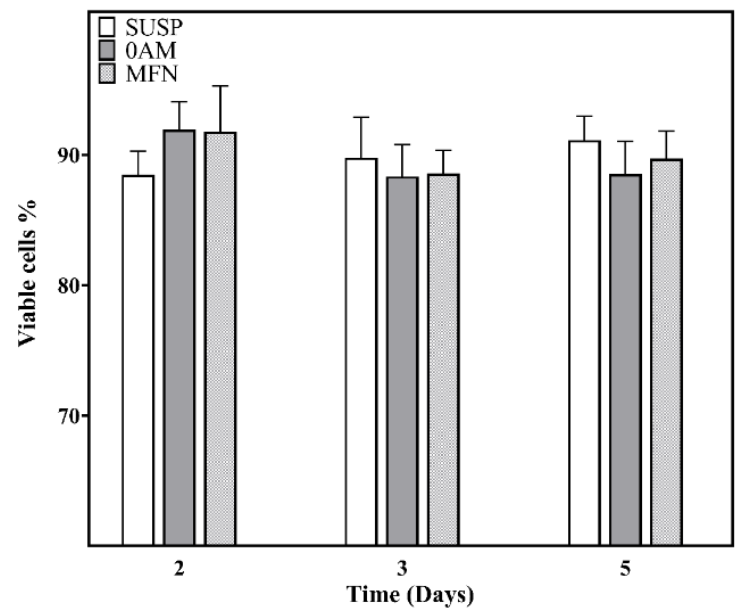

Figure 18. Results of cell cycle and cell viability assays at 2, 3 and 5 days. A) Fraction of cells in $\mathrm{G}_{0}-\mathrm{G}_{1}$ phase, B) Percentage of viable cells. SUSP: suspension culture without microspheres, 0AM: uncoated acrylic microspheres without acrylic acid, and MFN: acrylic microspheres without acrylic acid coated with fibronectin. Graph shows mean \pm standard deviation.

\subsubsection{Influence of integrin $\beta_{1}$ on cell adhesion to fibronectin and cell growth}

It has been shown in the literature that the MPCs-FN adhesion is mediated by VLA4 integrin, which is an integrin dimer of the integrin subunit $\alpha 4$ and integrin $\beta_{1}$. One of the characteristics of integrins is that they can assume multiple functional states. At the same time, it has been found that the union of the ligands mediated by integrin depends on divalent cations, which can be responsible for producing conformational changes in the integrin and thus trigger an increase in the capacity for union of the integrins with the 
ligands, this activation of the integrins being related to changes in the affinity for ligands $(133,134)$. As reviewed above in sections 1.3.1 and 1.4, VLA-4-mediated cell adhesion to VCAM-1 and to FN takes place through the CS1 region. For this reason, and taking into account the role of the presence of divalent cations in the activation of integrins, it is not unexpected that Masumoto et al. in 1993 (134) observed that the adhesion towards the CS1 region was less effective in the presence of $\mathrm{Ca}^{2+}$ cations than $\mathrm{Mg}^{2+}$. Later on, it was possible to determine in $\mathrm{mPCs}$ samples from patients with MM that from among a variety of divalent cations used, the activity of the integrin $\beta_{1}$ is maximized in the presence of $\mathrm{Mn}^{2+}$, being the integrin $\beta_{1}$ activity related to the adhesion to the FN. This integrin $\beta_{1}$ FN union is higher in patients that present an active form of integrin $\beta_{1}$ than with mPCs at a low-affinity state of $\beta_{1}$ (135). Also, it was postulated that the presence of low-affinity state $\beta_{1}$ was not only related to decreased adherence but could independently be related to improved cell proliferation.

In order to determine whether the activity of the integrin $\beta_{1}$ affects cell proliferation, an assay was performed incorporating divalent $\mathrm{Mn}^{2+}$ cations to the culture medium, thus improving the activity of this integrin. Since Martínez-Viñambres et al. in 2012 (135) observed that in mPCs of patients the maximum activity of $\beta_{1}$ was reached at values of $0.5 \mathrm{mM}$ of $\mathrm{Mn}^{2+}$, this amount of $\mathrm{Mn}^{2+}$ was used by adding to the culture medium $0.5 \mathrm{mM}$ of $\mathrm{MnCl}_{2}$. Once the experiment was set up, by seeding $1 \times 10^{5}$ cells in a conventional 2D culture with $\mathrm{MnCl}_{2}$ (2D $\left.\beta 1\right)$, proliferation was evaluated through a PicoGreen assay on days 2, 5 and 7. In each day it was possible to see how the incorporation of divalent cations, and therefore a more active state of integrin $\beta_{1}$, had a negative impact on cell proliferation as Martínez-Viñambres et al. in 2012 (135) hypothesized, observing a significant reduction in the number of cells between the control condition and the condition with $\mathrm{MnCl}_{2}$ (Figure 19). 


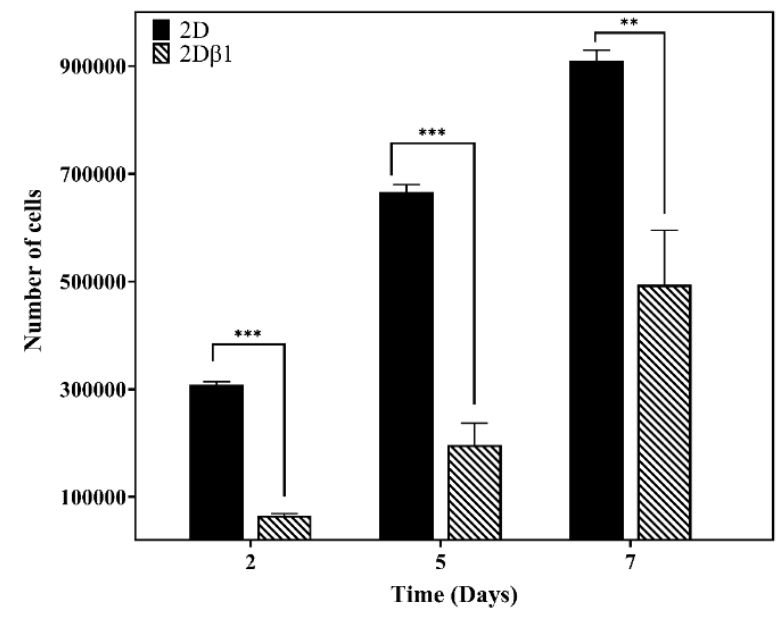

Figure 19. Proliferation assay at 2, 5 and 7 days on conventional $2 \mathrm{D}$ culture (2D) vs. conventional 2D culture in the presence of $\mathrm{MnCl}_{2}(2 \mathrm{D} \beta 1)$. Graph shows mean \pm standard deviation. The level of statistical significance is shown by the following legend: $\left.{ }^{* *}\right)$ p-value $\leq 0.01$, $\left.{ }^{* * *}\right)$ p-value $\leq 0.001$.

To confirm that increased integrin $\beta_{1}$ activity improves cell-FN adhesion through an increase in the number of cells arrested in $\mathrm{G}_{0}-\mathrm{G}_{1}$ phase, a cell cycle assay at 48 hours and cell viability assay at 24-48 hours were performed in a 3D environment incorporating different conditions with $0.5 \mathrm{mM}$ of $\mathrm{MnCl}_{2}$, including: SUSP with $\mathrm{MnCl}_{2}$ (SUSP $\beta 1$ ), $0 \mathrm{AM}$ with $\mathrm{MnCl}_{2}(0 \mathrm{AM} \beta 1)$, and $\mathrm{MFN}$ with $\mathrm{MnCl}_{2}(\mathrm{FN} \beta 1)$. As the increase of $\beta_{1}$ activity reduces cell proliferation (Figure 19), it was decided to seed $3.5 \times 10^{5}$ cells to have enough events for cell cycle assay. Due to FN, the FN $\beta 1$ condition presents a higher arrest at $\mathrm{G}_{0}$ $\mathrm{G}_{1}$ phase of $27 \%$ with respect to the rest of the conditions (Figure 20A), with little difference between the SUSP $\beta 1$ and OAM $\beta 1$ conditions. These differences are consistent with studies of mPCs from patients with MM (135) that with increased activity of integrin $\beta_{1}$ there is an increase in cell adhesion to FN, finding in our case a high percentage of cells under FN $\beta 1$ conditions $(87 \%)$ arrested in $\mathrm{G}_{0}-\mathrm{G}_{1}$ phase. The results were compared with those obtained on day 2 of section 4.2.3, being able to observe (Figure 20B) that a more active state of $\beta_{1}$ not only increased the cell adhesion to FN, with an increase of the $\mathrm{G}_{0}-\mathrm{G}_{1}$ phase of $18 \%$ between FN $\beta 1$ and MFN, but also SUSP $\beta 1$ and $0 A M \beta 1$ conditions showed a $9 \%$ increase in the $\mathrm{G}_{0}-\mathrm{G}_{1}$ phase with respect to AGM and SUSP. These results lend support to one of the hypotheses that the reason for a reduction in proliferation observed (Figure 19) is because the cell is adopting a series of mechanisms that make them remain in a quiescent state being arrested in $\mathrm{G}_{0}-\mathrm{G}_{1}$ phase. 
The fact that the fraction of cells arrested in the $\mathrm{G}_{0}-\mathrm{G}_{1}$ phase in SUSP and 0AM control conditions was $9 \%$ higher when integrin $\beta_{1}$ was activated than when it was not, could have been the result of the adhesion of cells to proteins adsorbed from the culture medium onto either the microspheres (in 0AM condition) or on the walls and bottom of the well (in SUSP condition). This adhesion was also favoured by the activation of integrin $\beta_{1}$. It is worth noting that in the case of the $\mathrm{FN} \beta 1$ condition the fraction of arrested cells was much higher, reaching values of $87 \%$, which meant $18 \%$ more than MFN, when integrin $\beta_{1}$ is in a low-affinity state as compared to conditions that incorporate $\mathrm{MnCl}_{2}$.

A

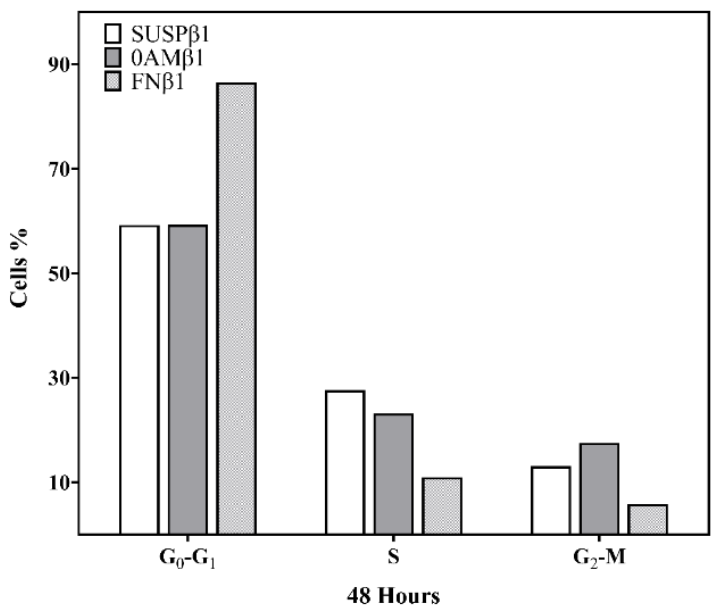

B

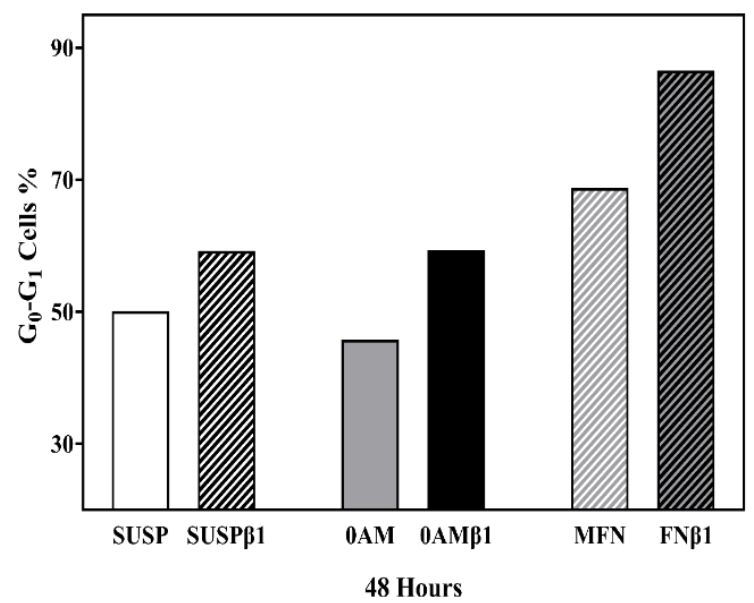

Figure 20. A) Fraction of cells in $\mathrm{G}_{0}-\mathrm{G}_{1}, \mathrm{~S}$ and $\mathrm{G}_{2}-\mathrm{M}$ phases with the incorporation on cell culture medium of divalent cations $\left(\mathrm{MnCl}_{2}\right)$. B) Comparative results of cell cycle assay on conditions with $0.5 \mathrm{mM}$ of $\mathrm{MnCl}_{2}$ (SUSP $\beta 1,0 A M \beta 1$ and FN $\beta 1$ ) and without (SUSP, 0AM and MFN). SUSP: suspension culture without microspheres, SUSP $\beta 1$ : suspension culture without microspheres with $\mathrm{MnCl}_{2}, 0 \mathrm{AM}$ : uncoated acrylic microspheres without acrylic acid, $0 \mathrm{AM} \beta 1$ : uncoated acrylic microspheres without acrylic acid with $\mathrm{MnCl}_{2}$, MFN: acrylic microspheres without acrylic acid coated with fibronectin, FN $\beta 1$ : acrylic microspheres without acrylic acid coated with fibronectin and with $\mathrm{MnCl}_{2}$.

However, in the cell viability assay a mean mortality of $39.3 \pm 3 \%$ was observed at both 24 and 48 hours, with the presence of $\mathrm{MnCl}_{2}$ in each condition (Figure 21). However, these same conditions without the presence of $\mathrm{MnCl}_{2}$ (Figure 18B) presented a mean viability at 48 hours of $89.8 \pm 2.5 \%$. As mentioned in Section 4.2 one of the problems with the cell cycle assay is that the presence of dead cells can increase $\mathrm{G}_{0}-\mathrm{G}_{1}$ 
peaks, suggesting that the reduction of cell numbers in proliferation assay (Figure 19) is due to a high mortality rate instead of a true increase in the percentage of cells in $\mathrm{G}_{0}-\mathrm{G}_{1}$ phase. Nevertheless, with the results observed and with the same mortality in each of the conditions, it can be concluded that the increased activity of integrin $\beta_{1}$ favours the adhesion of the cells to FN. Independently, it has been determined that this increase negatively affects cell growth, that could be related to the arrest of cells in the $\mathrm{G}_{0}-\mathrm{G}_{1}$ phase or by adopting some pathways that increase cell mortality. It is worth noting that no previous studies on the effect of $\mathrm{MnCl}_{2}$ on cell mortality evaluated by means of viability tests can be found in the literature (135).

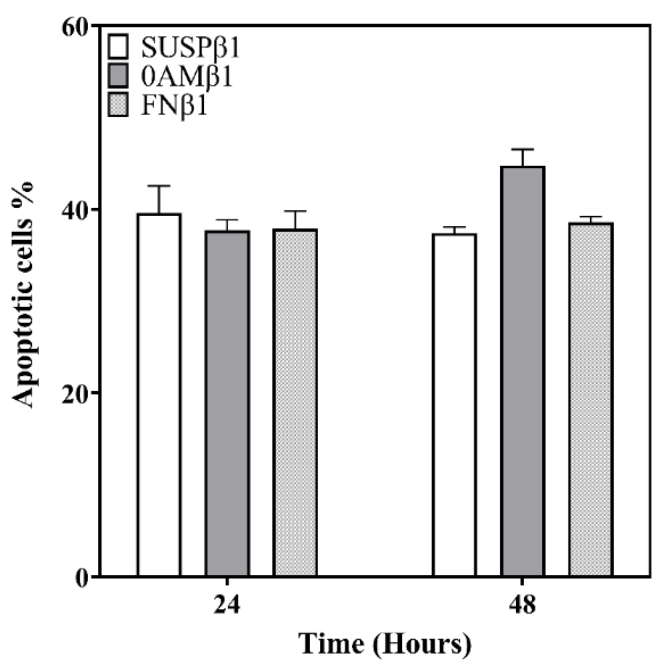

Figure 21. Percentage of non-viable cells in cell culture conditions with the incorporation of $\mathrm{MnCl}_{2}$. SUSP $\beta 1$ : suspension culture without microspheres with $\mathrm{MnCl}_{2}, 0 \mathrm{AM} \beta 1$ : uncoated acrylic microspheres without acrylic acid with $\mathrm{MnCl}_{2}, \mathrm{FN} \beta 1$ : acrylic microspheres without acrylic acid coated with fibronectin and with $\mathrm{MnCl}_{2}$. Graph shows mean \pm standard deviation.

\subsubsection{Cell behaviour in an environment with the presence of heparin or heparan sulphate}

The microspheres containing AAc at their surface allowed for preparing microgels containing Hep and HS. The influence of these biomolecules on biological responses was firs assessed with a viability assay. The viability assay was performed at day 2, 5 and 7 , seeding $1.5 \times 10^{5}$ cells using 2D and 0AM as control conditions. As can be seen in Figure $22 \mathrm{~A}$, while the control conditions showed normal mortality values of around $10 \%$, it was surprising to see that the MHep and MHS conditions had a mortality value of $95 \%$. 
A

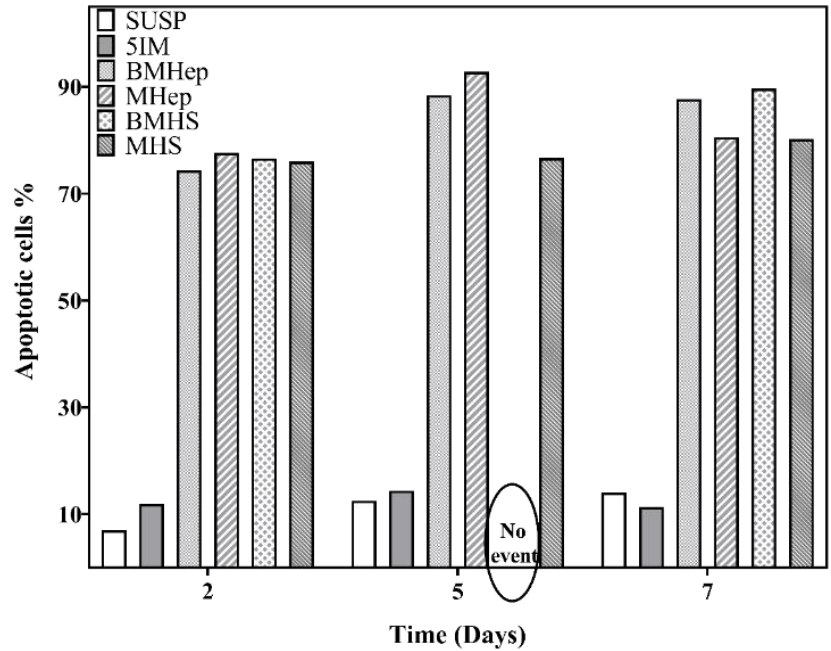

B

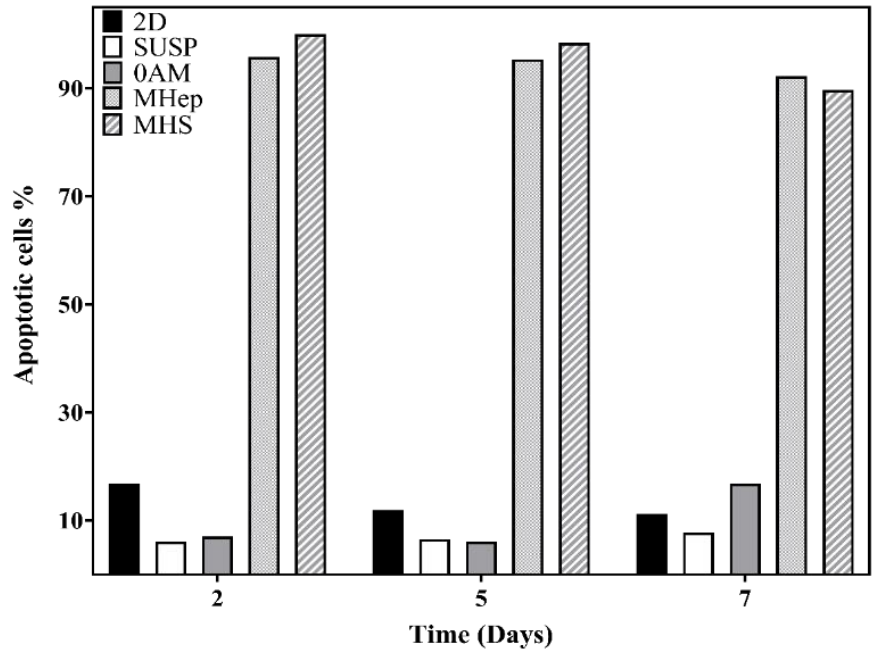

Figure 22. Cell viability assays showing the percentage of apoptotic cells at 2, 5 and 7 days. A) Results using 2D, SUSP and 0AM as control conditions and functionalized microspheres of MHep and MHS as studied conditions. B) Results using SUSP and 5IM as control conditions and functionalized microspheres of MHep, MHS, BMHep and BMHS as studied conditions. 2D: conventional 2D culture, SUSP: suspension culture without microspheres, 0AM: uncoated acrylic microspheres without acrylic acid, 5IM: uncoated acrylic microspheres with 5\% of acrylic acid blocking active ester, MHep: acrylic microspheres with 5\% of acrylic acid coated with heparin, MHS: acrylic microspheres with 5\% of acrylic acid coated with heparan sulphate, BMHep: acrylic microspheres with 5\% of acrylic acid blocking active ester before coating with heparin, BMHS: acrylic microspheres with 5\% of acrylic acid blocking active ester before coating with heparan sulphate. 
Due to the high mortality, samples were unified into a single tube that was analysed by FC. Because of this high mortality it is suspected that step 5 of the functionalization process was not carried out correctly, and that a stable active ester could have remained that gave rise to the generation of toxic effects for the cells. Another hypothesis is that by incorporating ETA once the functionalization of the biomolecules had been performed, it is possible that Hep and HS interfered in some way with the inactivation of the stable active ester present on the surface of the microspheres. Therefore, it was decided to perform another assay by incorporating two new conditions: where the blocking step with ETA was done once step 2 (Figure 6) is done, and to proceed to add the Hep (BMHep) or HS (BMHS) once the blocking of the stable active ester is done. In addition, in order to discard that the problem could be the presence of ETA, 5AM was used as control, activating their carboxyl groups by carbodiimide reaction and inactivating the stable active ester with the primary amine group of the ETA (5IM). However, as can be seen in Figure 22B, independent of the steps by which ETA blocks the active ester, while the 5IM condition does not present any type of toxicity, each of the Hep and HS conditions had high levels of mortality on each of the days, with no events detected under the BMHS condition on day 5, possibly due to the fact that during the centrifugation steps and because of its low cell density, the cell pellet may have been dragged along. With these results and with the incorporation of the 5IM condition it is demonstrated that the toxicity observed in the conditions with Hep and HS cannot be related to the presence of ETA nor to the possibility that they have a stable active ester. Thus, it seems that Hep and HS have a negative effect on mPCs, maybe due to the presence of high concentrations of both biomolecules. This hypothesis could be reasonable for the Hep condition due to the fact that approximately $6.83 \mu \mathrm{g}$ per $\mathrm{mg}$ of microsphere was available, which, in performing the culture using $80 \mathrm{mg}$ of microgel, translated to a total amount of Hep of approximately $546.4 \mu \mathrm{g}$ available in each well. This might be hypothesized to be too high a level, if it is compared with other ECM components dissolved in the culture medium, as for instance HA in the range of 50-60 $\mu \mathrm{g}$ per well $(64,136)$. However, this negative effect on mPCs was also observed with HS, which, with approximately $0.95 \mu \mathrm{g}$ per mg of microsphere, would have a much smaller quantity in each well than Hep, with approximately $76 \mu \mathrm{g}$ of HS per well. Another hypothesis to explain the high level of mortality could be related to the work done by Ritchie et al. in 2011 (137), which by employing SST0001, a chemically modified heparin, observed that it inhibited the activity of heparanase, acting as a potent inhibitor 
of in vivo myeloma growth. Because Hep and HS are chemically very similar, it is possible that both act in a similar way to inhibit heparanase activity and that this is causing the observed high mortality. However, more studies are needed to further elucidate the mechanisms by which Hep and HS are exhibiting this negative behaviour on mPCs.

\subsubsection{Concluding remarks related to cell behaviour in a 3D culture platform based on microgel}

The first feature analysed in our 3D culture platform was whether the presence of the microgel affects cell viability as compared to suspension culture without microspheres, and how the concentration of microspheres in the microgel affects cell growth. In this way it can be observed on Day 5 (Figure 15B) how there was an increase in cell proliferation attributable to the microgel configuration of the platform, that was present in the acrylic microgel environment even at the lowest tested microsphere/liquid medium volume percent of $6.89 \% \mathrm{v} / \mathrm{v}$ (Figure 15B). This cell proliferation was further affected by rising microsphere concentrations, stepwise increasing at $10.34 \% \mathrm{v} / \mathrm{v}$ and $13.8 \% \mathrm{v} / \mathrm{v}$, before having a decline at $17.2 \% \mathrm{v} / \mathrm{v}$, which was nevertheless still statistically significantly higher on Day 5 than the suspension without microspheres. This increment of proliferation capacity was smaller and did not reach statistical significance for alginate microspheres (Figure 17B). This proliferation capacity is different from the microcarriers that are used in the literature (138), in which the microspheres act as a support for adherent cells as in the case of MSCs, increasing the growth surface area and consequently cell growth in small volumes of medium (138). In our 3D culture platform, we work with nonadherent cells, so our model is not acting as a system that increases the growth surface area of the cells. We attribute this observed cell growth to the property of the microgel, in which the cells, being surrounded by microspheres, particularly when these are of a very similar size to the cell size (as in the acrylic model), and with the culture kept in a state of continuous agitation, are at a very short distances from each other increasing the direct cell-cell contact, as visually suggested in Figure 4C, 4D, 4E and 4F, causing an improvement in proliferation. Also, the size of the microsphere has an influence because the smaller the size of the microspheres, the more microspheres per volume there will be in the culture medium, which will increase cell-cell contact. This would explain why the 
proliferation is more remarkable with small microspheres (Figure 15B) than with large microspheres, which did not reach statistical significance (Figure 17B). This effect is not surprising since, in other cell lines it has been described that increasing direct cell-cell contact increases cell proliferation (139).

At the same time, it could be observed that the cell culture with OAM maintained a mean viability of $88.9 \pm 1.9 \%$ making it possible to rule out any cytotoxicity generated by the acrylic material itself (Figure 15C and 17B). This was also confirmed with the alginate microspheres, maintaining a mean viability of $91 \pm 2.4 \%$ (Figure 17C).

After verifying the microspheres/liquid-medium volume percent used for cell cultures, the cellular response was evaluated in terms of the biomolecules present in the microspheres. In this way, our results in the acrylate microspheres with FN allow us to guarantee that our 3D model can reproduce the well-known effect of adhesion of mPCs to $\mathrm{FN}$ by arresting the cells in $\mathrm{G}_{0}-\mathrm{G}_{1}$ phase (Figure $18 \mathrm{~A}$ ). As the adhesion is mediated by the action of VLA-4 integrin, it could be noted that a greater activity of the subunit integrin $\beta_{1}$ increased the adhesion of the $\mathrm{mPCs}$ to the $\mathrm{FN}$ by increasing the percentage of cells arrested in phase $\mathrm{G}_{0}-\mathrm{G}_{1}$ (Figure 20A). It was also observed that independently of the adhesion to $\mathrm{FN}$, the increased activity of integrin $\beta_{1}$ was related to the generation of a low cellular growth (Figure 19), which could be due either to an increase of cells in a quiescent state (Figure 20B) or to an increase in cell mortality (Figure 21). Continuing with the acrylate microspheres, it can be appreciated that independently from the activation of carboxyl groups by the carbodiimide reaction as well as the addition of ETA to block activated ester groups, the presence of both Hep and HS resulted in a high cell mortality (Figure 22A and 22B), this being one of the hypotheses that their presence inhibits heparanase activity. As for the results with the alginate microspheres, it was possible to confirm the hypothesis that HA promotes cell proliferation in an IL-6 independent cell line, possibly by the upregulation of bcl-2 or to the increased activity of NF-kB, without any effect on proliferation for the COL condition (Figure 17A). These results were corroborated by cell cycle assay (Figure 17B) and validated as to the absence of cytotoxicity under each of the conditions (Figure 17C). In this way, it was possible to corroborate that the cellular response differs according to the biomolecule grafted on the surface of the material, being able to generate a three-dimensional environment with the capacity of the mPCs to interact with different ECM components. 


\subsection{Drug resistance induced by the extracellular matrix components presented in the microgel}

One of the problems in MM treatment is the appearance clones resistant to therapy, which result in clinical relapses. For this reason, the testing of different drugs in order to predict which pharmacological strategy is most advisable for each patient is currently one of the research goals in this field. In the developed models it has been shown that the differences between 2D and 3D cultures in drug susceptibility assays are mainly due to the unnatural microenvironment of conventional 2D cultures. In these models, as they lack interaction between mPCs and the ECM components, the cellular response to the drug is altered (140). This is because the adhesion between mPCs-ECM components leads to the generation of DR, in the so-called CAM-DR effect (38). For this reason, a series of drug assays were carried out with different ECM components grafted onto the surface of the microspheres, with the aim to validate that the system enables the generation of DR through the adhesion of mPCs with the biomolecules functionalizing the microspheres. To validate the predictive capacity of our novel culture platform, we first confirmed that our system was capable of reproducing the CAM-DR effect described for HA and FN in the literature $(28,64)$, controlling for the possibility that the presence of the microgel itself could lead to the generation of resistance, in which somehow the microspheres could interfere with the presentation of the drugs to cells. In the case of COL, whose capacity for inducing CAM-DR has not been previously studied, as far we know, we proceeded to evaluate its effect in the three-dimensional environment. One of the main characteristics of our culture model that differs from the $2 \mathrm{D}$ cultures is that it has a better conformation of the biomolecules. In the case of FN, for example, while in the 2D cultures the FN is adsorbed onto the bottom of the well, in our model it is possible to have a PEA material which induces the fibrillation of FN, resulting in a better representation of the effect of the biomolecule as it would happen in vivo. In our CAM-DR experiments two of the most in vitro and in vivo studied drugs in MM, DEX and BRZ, were used, where the adhesion of mPCs to FN and HA is known to induce DR against DEX $(28,64)$. As for the biomolecules selected for the pharmacological assay, HS and Hep were excluded due to their high level of cell mortality show in section 4.2 .3 , so that we carried out the pharmacological assay using alginate microspheres to analyse the action of HA and COL, and 0AAc microspheres for the analysis of FN. 


\subsubsection{Cell adhesion to hyaluronic acid and collagen type I and its effect on drug resistance to dexamethasone and bortezomib}

According to the literature, different studies have been carried out to compare the effect of using low-dose DEX vs high-dose DEX in patients with MM, where while the use of high dose DEX favours overcoming disease resistance, low-dose DEX produces less toxicity $(24,105,140)$. Because of the clinical repercussions of using low-dose or high dose DEX in MM patients [25-27], we performed a viability test to adjust DEX dosage. This experiment was carried out in conventional 2D culture at 72 hours, varying the DEX dosage from 1 to $10^{3} \mu \mathrm{M}$. Following the results of Figure 23, it was decided to use for the CAM-DR assays a DEX dose of $10^{3} \mu \mathrm{M}$, with a cell mortality (apoptosis) of around $70 \pm$ $1.1 \%$.

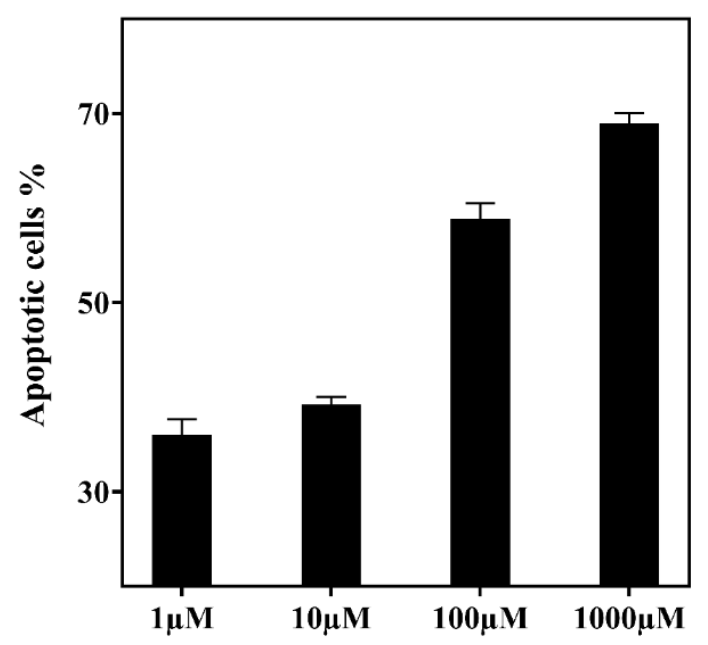

Figure 23. Percentage of apoptotic cells in 2D culture after exposure to different DEX doses. Graph shows mean \pm standard deviation.

The role of HA in triggering a CAM-DR effect to DEX in the RPMI 8226 cell line has already been described in $2 \mathrm{D}$ cultures, and shown to act through the upregulation of bcl-2 and the activation of NF- $\mathrm{KB}$ (64). Therefore, DEX was used to corroborate that our $3 \mathrm{D}$ platform is able to reproduce the CAM-DR effect, and as a positive control for any interference that may occur during the drug assays. $1.5 \times 10^{5}$ cells were exposed to $10^{3} \mu \mathrm{M}$ of DEX for 72 hours and $10 \mathrm{nM}$ of BRZ for 48 hours (141), including a non-drug control for each of the conditions, that was used to normalize the viability results observed after 
the action of the drug (data not shown). Cell mortality was evaluated by viability assay. As seen in Figure 24A, after 72 hours of DEX exposure, no differences in apoptosis were observed between conventional 2D culture $(77.8 \pm 8.1 \%)$, 3D SUSP $(75.6 \pm 6 \%)$ and AGM $(79.2 \pm 3.4 \%)$. However, when the microgel was functionalized with HA and/or COL the mortality decreased reaching values of $30.4 \pm 2.4 \%$ for the HAM, $39.5 \pm 3.6 \%$ for COLM and $44.6 \pm 5.1 \%$ for the MIX, or an overall reduction of around of $39 \%$ with respect to control conditions. Consistent with the literature (64), expected results were achieved with microspheres whose last layer was HA, presenting the CAM-DR effect by the action of HA. Interestingly, the results also show the induction of a CAM-DR effect to DEX being promoted by the presence of COL in cell environment. Further studies will be necessary to clarify the mechanisms of COL-induced DR on MM cells. First of all, it will be important to discard the possibility that the COL microspheres containing sublayers of HA may have the resistance observed under supposed COL conditions due to the presence of residual layers of HA that may have remained in the final layer of the microspheres. In this regard, the results of PicoGreen and cell cycle techniques showed that the characteristic effect of HA in increasing the proliferative capacity of mPCs (Figure 17A and 17B) was not observed among the microspheres coated by HA-COL LbL in which the last layer is COL. Thus, our hypothesis is that the interaction of mPCs with COL is mediated by syndecan-1, which in turn promotes Wnt signaling, and may be responsible for the DR $(72,74)$. 

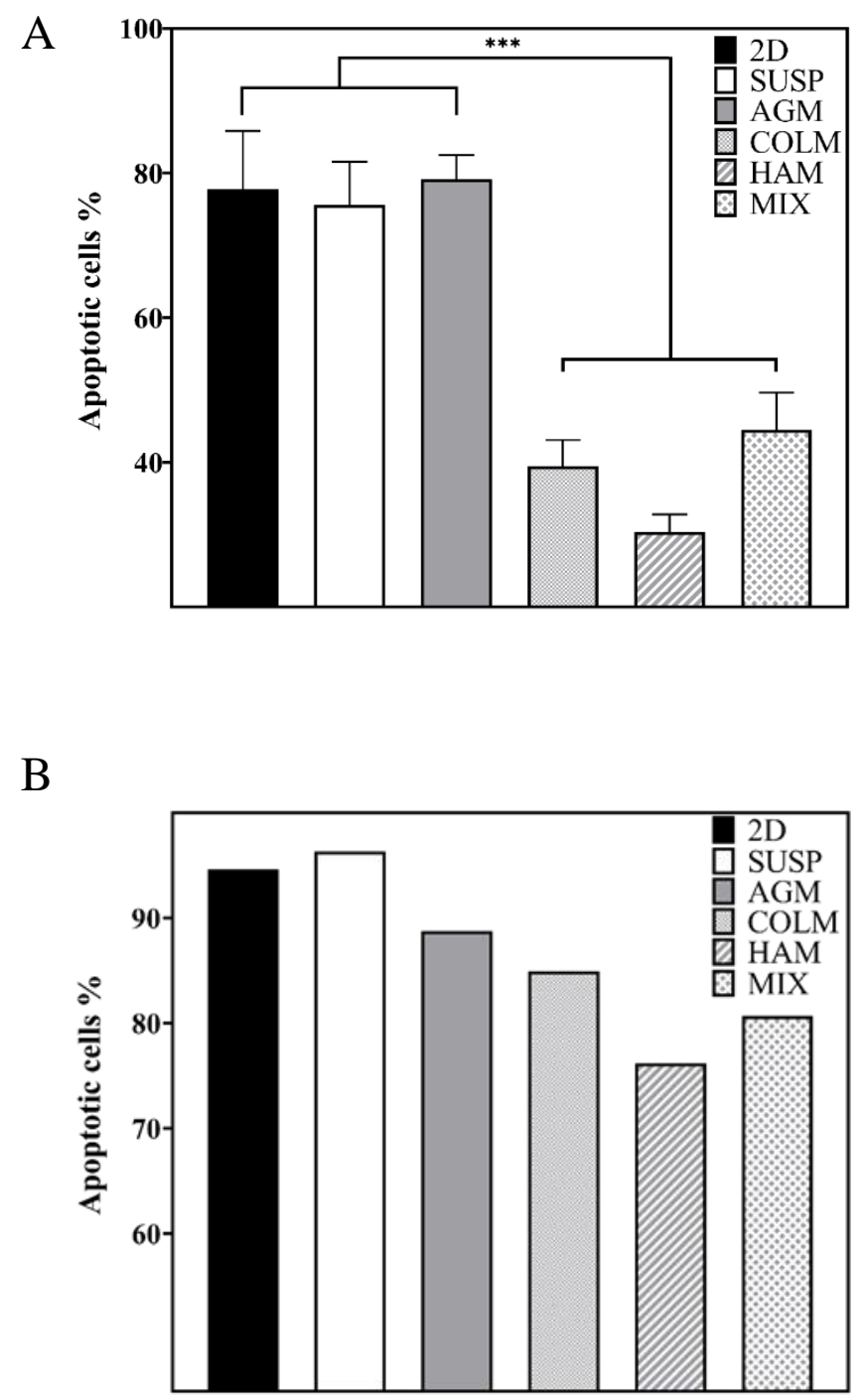

Figure 24. Influence of the presence of HA or COL on the development of drug resistance to A) $10^{3} \mu \mathrm{M}$ high-dose DEX at 72 hours, B) $10 \mathrm{nM} \mathrm{BRZ} \mathrm{at} 48$ hours. 2D: conventional 2D culture, SUSP: suspension culture without microspheres, AGM: uncoated alginate microspheres, COLM: alginate microspheres coated with collagen type I, HAM: alginate microspheres coated with last layer of HA, MIX: microgel consisting of $50 \%$ of HAM and 50\% of COLM. Graph A shows mean \pm standard deviation. The level of statistical significance is shown by the following legend: $(* * *)$ p-value $\leq 0.001$.

In the case of BRZ, since no relevant literature was found on the impact of the use of a variety of treatments using low or high dose BRZ on MM patients, it was decided to choose for the assay a known concentration taken from the literature of $10 \mathrm{nM}$ [43]. After 48 hours of drug exposure, due to the high cell mortality observed in each of the conditions and the few events acquired by the flow cytometer, samples were unified into a single tube that was analysed in the equipment. Cell mortality reached $94.6 \%$ in 2D and $96.4 \%$ in SUSP. In the case of 3D culture high cell mortality is also produced: $88.8 \%$ in AGM, 84.9\% in COLM, 76.2\% in HAM, and 80.7\% in MIX (Figure 24B). The difference 
observed between 2D and 3D conditions may be the result of the favoured cell-cell contact in a microgel environment as mentioned in Section 4.2, which by promoting cell growth could result in the presence of a higher percentage of viable cells. Moreover, as mentioned in Section 4.2.2, HAM and MIX conditions due to the presence of HA, have a higher cell proliferation than AGM and COLM conditions, which would also explain how HAM and MIX conditions have a slightly lower mortality in the presence of BRZ than AGM and COLM conditions (Figure 24B). However, these differences are not significant enough to attribute to HA and COL a CAM-DR effect against BRZ as occurs with DEX.

\subsubsection{Cell adhesion to fibronectin and its effect on drug resistance to dexamethasone and their cell adhesion reversion by the effect of bortezomib}

The adhesion of the mPCs to FN as well as its CAM-DR effect to DEX has been previously studied in conventional $2 \mathrm{D}$ cultures, in which $\mathrm{FN}$ is adhered to the bottom of the well, resulting in the arrest of $\mathrm{mPCs}$ in the $\mathrm{G}_{0}-\mathrm{G}_{1}$ phase of the cell cycle and generation a CAM-DR effect to DEX $(28,62)$. Once the adhesion of the mPCs to FN was confirmed in section 4.2.3, as in the case with alginate microgel, it was assessed whether the presence of acrylate microgel could interfere with drug assays. For this purpose, the CAM-DR effect of FN was evaluated against BRZ and high-dose DEX, as both drugs are used in clinical practice against MM and their in vitro effects on the CAM-DR against DEX and mPCs-FN adhesion $(28,32)$ are known for both of them. For DR assays $1.5 \times 10^{5}$ cells were seeded and exposed to different conditions: $10^{3} \mu \mathrm{M}$ DEX for 72 hours, $5 \mathrm{nM}$ BRZ for 48 hours, and a last condition combining the effect of both drugs incorporating for the first 24 hours only DEX, and then 48 hours incorporating DEX and BRZ. The combination of drugs is one of the most widely used strategies in clinical practice for the treatment of haematological neoplasms, because it produces synergistic activity which increases the anti-tumor effect (29). The decision to use half of the BRZ concentration was due to the high cell mortality observed during the experiments described in section 4.3.1.

Apoptotic cells were analysed by viability assay, resulting in expected results with a non-CAM-DR effect of FN to BRZ, with all conditions showing a similar mortality: 
$35.5 \pm 2.4 \%$ in SUSP, $35.2 \pm 1.2 \%$ in $0 \mathrm{AM}$ and $36 \pm 3.4 \%$ in MFN (Figure 25). Also, in the case of DEX, due to the arrest of $\mathrm{G}_{0}-\mathrm{G}_{1}$ phase under FN conditions, there was a significant decrease in cell mortality (i.e., drug resistance) under MFN conditions as compared to SUSP and OAM, with MFN having a mortality of $54.6 \pm 2.75 \%$ compared to $72 \pm 2.2 \%$ for SUSP and $73.9 \pm 1.9 \%$ for OAM (Figure 25), representing mortalities that were $17.35 \pm 4.9 \%$ and $19.25 \pm 1 \%$ higher under SUSP and OAM conditions, respectively, as compared with MFN. Finally, since the action of the BRZ has been associated with the downregulation of VLA-4, it was decided to combine the effect of BRZ and DEX in the presence of FN with the aim of testing the hypothesis that the action of BRZ prevents the adhesion of mPCs-FN through the downregulation of VLA-4 and in this way overcomes the CAM-DR effect, similar to the mecahanism described previously in the adhesion of mPCs-BMSCs (32). We observed no significant difference of mortality between SUSP $(78.8 \pm 1.4 \%)$ and OAM $(79.3 \pm 0.2 \%)$ conditions with DEX+BRZ, showing the SUSP condition with DEX+BRZ an increased mortality of $6.9 \pm 2.7 \%$ with respect to that observed with only DEX and the OAM condition with DEX+BRZ an increased mortality of $5.4 \pm 1.7 \%$ with respect to OAM condition with only DEX. MFN condition with DEX+BRZ $(66.9 \pm 4.6 \%)$ show an increase mortality of $12.3 \pm 2.2 \%$ with respect to that observed with only DEX, presenting the double increase in mortality compared to SUSP and OAM condition with DEX+BRZ. This is due to the downregulation of VLA-4 caused by BRZ that reduces the mPCs-FN adhesion and thereby overcomes the CAM-DR effect to DEX that initially presented the MFN condition. 


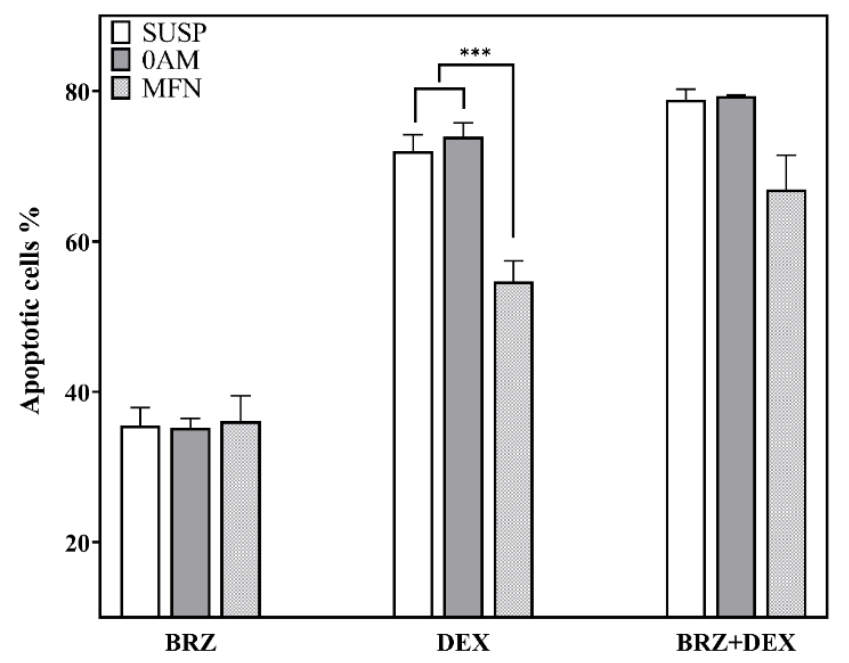

Figure 25. Results with FN condition on the development of drug resistance to $10^{3} \mu \mathrm{M}$ high-dose DEX (72 hours), $5 \mathrm{nM} \mathrm{BRZ} \mathrm{(48} \mathrm{hours)} \mathrm{and} \mathrm{the} \mathrm{effect} \mathrm{of} \mathrm{synergistic} \mathrm{activity} \mathrm{of} \mathrm{both} \mathrm{drugs} \mathrm{on} \mathrm{cell} \mathrm{viability.} \mathrm{SUSP:}$ suspension culture without microspheres, OAM: uncoated acrylic microspheres without acrylic acid. MFN: acrylic microspheres without acrylic acid coated with fibronectin. Graph shows mean \pm standard deviation. The level of statistical significance is shown by the following legend: $(* * *)$ p-value $\leq 0.001$.

\subsubsection{Concluding remarks related to drug resistance induced by cell adhesion to extracellular matrix components}

The development of a realistic in vitro disease model for MM that could be used in the evaluation of new antitumoral drugs or to personalize patient treatment is still a challenge. Such a culture platform would require an artificial three-dimensional environment in which the mPCs generate the same resistance to drugs as they do in vivo. The problem represents a huge challenge due to the importance of the medullary niche in disease development, where the adhesion of mPCs to BMSCs and ECM components has been shown to influence proliferation, growth, invasion, and DR of mPCs (142). In an environment lacking the key biomolecules with which mPCs interact, such as conventional 2D culture, the cellular response to the drug is altered due to its unnatural microenvironment (140). In addition, there is evidence that the behaviour of the mPCs in a 3D culture differs morphologically and physiologically from cells in 2D culture (105). Due to this issue, the development of new 3D systems that mimic the in vivo cell behaviour and provide more predictable results to in vivo tests is being carried out $(93,143,144)$. In this section a proof of concept has been set to demonstrate that with our $3 \mathrm{D}$ culture microgel system it is possible to predict the generation of DR due to the 
interaction of mPCs with specific biomolecules attached to microspheres, approximating the in vivo ECM environment. In the alginate microgel, the CAM-DR effect was observed against DEX under each of the conditions studied. In the cases of HA and FN (Figure $24 \mathrm{~A}$ and 25$)$, their effect confirm what has been described in previous works $(32,64)$. The hypothesis for the signaling route leading to CAM-DR is that the resistance generated in both cases is related to an increase in NF- $\kappa \mathrm{B}$ activity, and that, at the same time, cells adopt a different phenotype independent of the DR effect; namely, that when the adhesion to $\mathrm{FN}$ takes place, a nuclear accumulation of $\mathrm{p} 27^{\mathrm{kip} 1}$ protein is produced, which leads to the arrest of cells in the $\mathrm{G}_{0}-\mathrm{G}_{1}$ phase, leaving them in a quiescent state, and when the adhesion is to HA, it produces an increase in cell proliferation that could be associated with the upregulation of bcl-2. This hypothesis could maintain the idea that COL-induced DR to DEX (Figure 24A) might be related to the promotion of Wnt signaling, which causes an increase in NF- $\kappa \mathrm{B}$ activity without any change in cell phenotype. This theory is possible due to the cross regulation between Wnt and NF- $\kappa \mathrm{B}$ in which, despite being independent pathways, their activity is also regulated by direct interactions between both pathways (145). Regarding the BRZ assays we were able to confirm that each biomolecule did not generate a significant CAM-DR effect as observed with DEX (Figure 24B and 25). Moreover, the combined effect of drugs has corroborated the ability of BRZ to overcome the CAM-DR effect to DEX through the downregulation of VLA-4. In this way, it is possible to verify that our platform can reproduce the results obtained in previous published work.

The generation of a 3D culture system has made it possible to test the effect of different drugs on already studied ECM components, confirming in a $3 \mathrm{D}$ culture the results obtained in conventional $2 \mathrm{D}$ cultures and generating novel data. In addition to stimulating further research to elucidate the mechanisms involved in HA-induced cell proliferation, cell mortality caused by Hep and HS, or the possible generation of a CAMDR effect of COL to DEX, this study has developed a 3D culture platform that is easy to handle, with great versatility to combine different functionalized microspheres with different biomolecules in a single culture, opening up a wide range of possibilities for future studies to generate three-dimensional environments with the presence of several ECM components. Moreover, the validation of this culture platform has made it possible to further clarify the influence of several ECM components, representing a major advance in the development of new 3D culture platforms that will allow researchers to bring the results of in vitro MM models closer to the in vivo one. 


\section{Conclusions}

1. A culture platform is presented based on a biomimetic microgel, formed by synthetic microspheres whose surface has been coated with specific biomolecules of the bone marrow ECM. These microspheres are suspended in a liquid culture medium in which the MM cells are also included. The suspension is maintained during cell culture by orbital stirring. Cells and microspheres can be separated after culture by filtering or using a magnet if the microspheres contain magnetic nanoparticles.

2. Microsphere surface functionalization with engrafted biomolecules has been performed by two different routes: by covalent bonds to reactive groups exhibited on the surface of microspheres made of polyacrylate copolymers, and by layer-by-layer electrostatic bonding built on the surface of alginate microspheres.

3. The configuration of the cell culture in the acrylic microgel increases cell proliferation even in unfunctionalized systems, with cells cultured in suspension without any biomaterial. This feature is ascribed to the different cell-cell contact induced by the excluded volume corresponding to the microspheres.

4. Cell culture in the microgel can reach very high cell numbers, in the order of $3 \times 10^{3}$ cells per $\mu \mathrm{L}$, achieved by providing the dynamic condition sufficient nutrients and oxygen distribution for the cells, maintaining at day 7 a high viability in the order of $90 \%$.

5. The 3D culture platform allows the interaction between mPCs and ECM components on the surface of the microspheres, generating a different cellular response depending on the biomolecule used.

6. The presence of HA in the system further increases the proliferative capacity of the mPCs. In contrast, the presence of COL has no significant effect on cell growth.

7. The effect of cell adhesion to FN, mediated by $\alpha 4 \beta 1$ integrins, is reproduced in our system showing the arrest of cells in $\mathrm{G}_{0}-\mathrm{G}_{1}$ phase of the cell cycle. This effect is 
enhanced when the activity of subunit integrin $\beta 1$ is increased by the incorporation of $\mathrm{Mn}^{2+}$ divalent cation.

8. The results of the effect of Hep and HS and how integrin $\beta 1$ decreases cell growth are not totally conclusive, and must be studied further, comparing, in the case of Hep and HS, the effect of grafting variable amounts of the biomolecules onto the microspheres or of grafting by different functionalization processes, and, in the case of integrin $\beta 1$, studying different signaling pathways related to cell cycle or apoptosis.

9. As a proof of concept, the effect of HA and FN in the generation of CAM-DR effect to DEX in RPMI 8226 cell line has been verified. An association between COL and CAMDR effect to DEX, has been also found, although this requires further study. An analogous behavior has been observed both in a microgel in which half of the microspheres have on their surface HA and the other half COL, and in the microgel in which all the microspheres are coated with HA. The lack of CAM-DR effect against BRZ induced by the interaction with $\mathrm{HA}, \mathrm{COL}$ and $\mathrm{FN}$ has been confirmed, as well as the effect of BRZ to reduce the mPCs-FN adhesion, throught the downregulation of VLA-4, by studying the cell response to the combination of BRZ and DEX. Thus, the results obtained in this work represent the validation of a novel platform for the cell culture of mPCs cell lines, representing a step further in the generation of a realistic disease model for MM.

10. For future perspectives, this work offers a wide range of research opportunities such as the development of 3D cultures with different components of the ECM as well as the co-culture with stromal cells. Another line of research would be the validation of this platform for the culture of primary cells from patients with MM, which, once validated, could be applied for the testing and development of new drugs, allowing for a better understanding of their effects as well as the interaction between neoplastic cells and the bone marrow environment. 


\section{References}

1. Zambidis ET, Oberlin E, Tavian M, Péault B. Blood-Forming Endothelium in Human Ontogeny: Lessons From In Utero Development and Embryonic Stem Cell Culture. Trends Cardiovasc Med. 2006 Apr;16(3):95-101.

2. Orfao A, Matarraz S, Pérez-Andrés M, Almeida J, Teodosio C, Berkowska MA, et al. Immunophenotypic dissection of normal hematopoiesis. J Immunol Methods. 2019 Dec;475:112684.

3. Nagasawa T. Microenvironmental niches in the bone marrow required for B-cell development. Nat Rev Immunol. 2006 Feb;6(2):107-116.

4. Espeli M, Rossi B, Mancini SJC, Roche P, Gauthier L, Schiff C. Initiation of pre-B cell receptor signaling: Common and distinctive features in human and mouse. Semin Immunol. 2006 Feb;18(1):56-66.

5. Sapoznikov A, Pewzner-Jung Y, Kalchenko V, Krauthgamer R, Shachar I, Jung S. Perivascular clusters of dendritic cells provide critical survival signals to B cells in bone marrow niches. Nat Immunol. 2008 Apr 2;9(4):388-395.

6. Eaton-Bassiri A, Dillon SB, Cunningham M, Rycyzyn MA, Mills J, Sarisky RT, et al. Toll-Like Receptor 9 Can Be Expressed at the Cell Surface of Distinct Populations of Tonsils and Human Peripheral Blood Mononuclear Cells. Infect Immun. 2004 Dec;72(12):7202-7211.

7. Melchers F. Checkpoints that control B cell development. J Clin Invest. 2015 Jun 1;125(6):22032210.

8. Perez-Andres M, Paiva B, Nieto WG, Caraux A, Schmitz A, Almeida J, et al. Human peripheral blood B-cell compartments: A crossroad in B-cell traffic. Cytom Part B Clin Cytom. 2010;78B(S1):S47-60.

9. Johnsen HE, Bogsted M, Schmitz A, Bodker JS, El-Galaly TC, Johansen P, et al. The myeloma stem cell concept, revisited: from phenomenology to operational terms. Haematologica. 2016 Dec 1;101(12):1451-1459.

10. Khodadadi L, Cheng Q, Radbruch A, Hiepe F. The Maintenance of Memory Plasma Cells. Front Immunol. 2019 Apr 5;10(721).

11. van Zelm MC, van der Burg M, de Ridder D, Barendregt BH, de Haas EFE, Reinders MJT, et al. Ig gene rearrangement steps are initiated in early human precursor B cell subsets and correlate with specific transcription factor expression. J Immunol. 2006 Jun 15;176(12):7787.2-7787.

12. LeBien TW, Tedder TF. B lymphocytes: how they develop and function. Blood. 2008 Sep 1;112(5):1570-1580.

13. Abbas A, Lichtman AH, Pillai S. Cellular and Molecular Immunology 9th Ed. Cellular and Molecular Immunology. 2017.

14. Anderson KC, Carrasco RD. Pathogenesis of Myeloma. Annu Rev Pathol Mech Dis. 2011 Feb 28;6(1):249-274.

15. Qian J, Jin J, Luo H, Jin C, Wang L, Qian W, et al. Analysis of clinical characteristics and prognostic factors of multiple myeloma: a retrospective single-center study of 787 cases. Hematology. 2017 Sep 2;22(8):472-476.

16. Piechotta V, Jakob T, Langer P, Monsef I, Scheid C, Estcourt LJ, et al. Multiple drug combinations of bortezomib, lenalidomide, and thalidomide for first-line treatment in adults with transplantineligible multiple myeloma: a network meta-analysis. Cochrane Database Syst Rev. 2019 Nov $25 ; 2019(11)$

17. Firth J. Haematology: multiple myeloma. Clin Med (Northfield Il). 2019 Jan 16;19(1):58-60.

18. Longo D, Fauci A, Kasper D, Hauser S, Jameson L, Loscalzo J. Harrison: principios de medicina interna ( $18^{\circ}$ ed). In: Harrison Principios de Medicina interna. 2012.

19. Castells Garangou A. Farreras/Rozman medicina interna XVII ed. Farreras-Rozman: Medicina Interna. 2016.

20. Terpos E, Kleber M, Engelhardt M, Zweegman S, Gay F, Kastritis E, et al. European Myeloma Network Guidelines for the Management of Multiple Myeloma-related Complications. Haematologica. 2015 Oct 1;100(10):1254-1266.

21. Abe M, Hiura K, Wilde J, Shioyasono A, Moriyama K, Hashimoto T, et al. Osteoclasts enhance myeloma cell growth and survival via cell-cell contact: a vicious cycle between bone destruction and myeloma expansion. Blood. 2004 Oct 15;104(8):2484-2491. 
22. Silvestris F, Cafforio P, Tucci M, Dammacco F. Negative regulation of erythroblast maturation by Fas-L+/TRAIL+ highly malignant plasma cells: a major pathogenetic mechanism of anemia in multiple myeloma. Blood. 2002 Feb 15;99(4):1305-1313.

23. Dingli D, Ailawadhi S, Bergsagel PL, Buadi FK, Dispenzieri A, Fonseca R, et al. Therapy for Relapsed Multiple Myeloma. Mayo Clin Proc. 2017 Apr;92(4):578-598.

24. Burwick N, Sharma S. Glucocorticoids in multiple myeloma: past, present, and future. Ann Hematol. 2019 Jan 2;98(1):19-28.

25. Chauhan D, Auclair D, Robinson EK, Hideshima T, Li G, Podar K, et al. Identification of genes regulated by Dexamethasone in multiple myeloma cells using oligonucleotide arrays. Oncogene. 2002 Feb 21;21(9):1346-1358.

26. Hideshima T, Chauhan D, Richardson P, Mitsiades C, Mitsiades N, Hayashi T, et al. NF- B as a Therapeutic Target in Multiple Myeloma. J Biol Chem. 2002 May 10;277(19):16639-16647.

27. Robak P, Drozdz I, Szemraj J, Robak T. Drug resistance in multiple myeloma. Cancer Treat Rev. 2018 Nov;70:199-208.

28. Fei M, Hang Q, Hou S, He S, Ruan C. Adhesion to fibronectin induces p27Kip1 nuclear accumulation through down-regulation of Jab1 and contributes to cell adhesion-mediated drug resistance (CAM-DR) in RPMI 8,226 cells. Mol Cell Biochem. 2014 Jan 30;386(1-2):177-187.

29. Gandolfi S, Laubach JP, Hideshima T, Chauhan D, Anderson KC, Richardson PG. The proteasome and proteasome inhibitors in multiple myeloma. Cancer Metastasis Rev. 2017;36(4):561-584.

30. Robak P, Robak T. Bortezomib for the Treatment of Hematologic Malignancies: 15 Years Later. Drugs R D. 2019 Jun 16;19(2):73-92.

31. Anderson KC. Proteasome Inhibitors in Multiple Myeloma. Semin Oncol. 2009 Apr;36(SUPPL. 1):S20-26.

32. Hatano K, Kikuchi J, Takatoku M, Shimizu R, Wada T, Ueda M, et al. Bortezomib overcomes cell adhesion-mediated drug resistance through downregulation of VLA-4 expression in multiple myeloma. Oncogene. 2009;28(2):231-242.

33. Rückrich T, Kraus M, Gogel J, Beck A, Ovaa H, Verdoes M, et al. Characterization of the ubiquitin-proteasome system in bortezomib-adapted cells. Leukemia. 2009 Jun 19;23(6):10981105.

34. Bonnet D, Dick JE. Human acute myeloid leukemia is organized as a hierarchy that originates from a primitive hematopoietic cell. Nat Med. 1997 Jul;3(7):730-737.

35. Eppert K, Takenaka K, Lechman ER, Waldron L, Nilsson B, van Galen P, et al. Stem cell gene expression programs influence clinical outcome in human leukemia. Nat Med. 2011 Sep 28;17(9):1086-1093.

36. Prideaux SM, Conway O’Brien E, Chevassut TJ. The Genetic Architecture of Multiple Myeloma. Adv Hematol. 2014;2014:1-16.

37. Lohr JG, Stojanov P, Carter SL, Cruz-Gordillo P, Lawrence MS, Auclair D, et al. Widespread Genetic Heterogeneity in Multiple Myeloma: Implications for Targeted Therapy. Cancer Cell. 2014 Jan;25(1):91-101.

38. Vincent T, Mechti N. Extracellular matrix in bone marrow can mediate drug resistance in myeloma. Leuk Lymphoma. 2005 Jun 3;46(6):803-811.

39. Martin SK, Diamond P, Gronthos S, Peet DJ, Zannettino ACW. The emerging role of hypoxia, HIF-1 and HIF-2 in multiple myeloma. Leukemia. 2011 Oct 3;25(10):1533-1542.

40. Ria R, Vacca A. Bone Marrow Stromal Cells-Induced Drug Resistance in Multiple Myeloma. Int J Mol Sci. 2020 Jan 17;21(2):613.

41. Cassese G, Arce S, Hauser AE, Lehnert K, Moewes B, Mostarac M, et al. Plasma Cell Survival Is Mediated by Synergistic Effects of Cytokines and Adhesion-Dependent Signals. J Immunol. 2003 Aug 15;171(4):1684-1690.

42. Peperzak V, Vikström I, Walker J, Glaser SP, LePage M, Coquery CM, et al. Mcl-1 is essential for the survival of plasma cells. Nat Immunol. 2013 Mar 3;14(3):290-297.

43. Nguyen DC, Garimalla S, Xiao H, Kyu S, Albizua I, Galipeau J, et al. Factors of the bone marrow microniche that support human plasma cell survival and immunoglobulin secretion. Nat Commun. 2018 Dec 12;9(1):3698.

44. Gabler J, Wittmann J, Porstner M, Renz H, Jäck H-M, Abram M, et al. Contribution of microRNA 24-3p and Erk1/2 to interleukin-6-mediated plasma cell survival. Eur J Immunol. 2013 Nov;43(11):3028-3037.

45. Klein B, Tarte K, Jourdan M, Mathouk K, Moreaux J, Jourdan E, et al. Survival and Proliferation Factors of Normal and Malignant Plasma Cells. Int J Hematol. 2003 Aug 1;78(2):106-113.

46. Chu VT, Fröhlich A, Steinhauser G, Scheel T, Roch T, Fillatreau S, et al. Eosinophils are required for the maintenance of plasma cells in the bone marrow. Nat Immunol. 2011 Feb 9;12(2):151-159. 
47. Winter O, Moser K, Mohr E, Zotos D, Kaminski H, Szyska M, et al. Megakaryocytes constitute a functional component of a plasma cell niche in the bone marrow. Blood. 2010 Sep 16;116(11):1867-1875.

48. Wols HAM, Underhill GH, Kansas GS, Witte PL. The Role of Bone Marrow-Derived Stromal Cells in the Maintenance of Plasma Cell Longevity. J Immunol. 2002 Oct 15;169(8):4213-4221.

49. McCarron MJ, Park PW, Fooksman DR. CD138 mediates selection of mature plasma cells by regulating their survival. Blood. 2017 May 18;129(20):2749-2759.

50. Corre J, Mahtouk K, Attal M, Gadelorge M, Huynh A, Fleury-Cappellesso S, et al. Bone marrow mesenchymal stem cells are abnormal in multiple myeloma. Leukemia. 2007 May 8;21(5):10791088.

51. Fowler JA, Edwards CM, Croucher PI. Tumor-host cell interactions in the bone disease of myeloma. Bone. 2011 Jan;48(1):121-128.

52. Tian E, Zhan F, Walker R, Rasmussen E, Ma Y, Barlogie B, et al. The Role of the Wnt-Signaling Antagonist DKK1 in the Development of Osteolytic Lesions in Multiple Myeloma. N Engl J Med. 2003 Dec 25;349(26):2483-2494.

53. Gunn WG, Conley A, Deininger L, Olson SD, Prockop DJ, Gregory CA. A Crosstalk Between Myeloma Cells and Marrow Stromal Cells Stimulates Production of DKK1 and Interleukin-6: A Potential Role in the Development of Lytic Bone Disease and Tumor Progression in Multiple Myeloma. Stem Cells. 2006 Apr;24(4):986-991.

54. Moreaux J, Sprynski A-C, Dillon SR, Mahtouk K, Jourdan M, Ythier A, et al. APRIL and TACI interact with syndecan-1 on the surface of multiple myeloma cells to form an essential survival loop. Eur J Haematol. 2009 Aug;83(2):119-129.

55. Yanamandra U, Kumar SK. Minimal residual disease analysis in myeloma - when, why and where. Leuk Lymphoma. 2018 Aug 3;59(8):1772-1784.

56. Hazlehurst LA, Dalton WS. De Novo and Acquired Resistance to Antitumor Alkylating Agents. In: Cancer Drug Resistance. Totowa, NJ: Humana Press; 2007. p. 377-389.

57. Meads MB, Hazlehurst LA, Dalton WS. The Bone Marrow Microenvironment as a Tumor Sanctuary and Contributor to Drug Resistance. Clin Cancer Res. 2008 May 1;14(9):2519-2526.

58. Paiva B, Corchete LA, Vidriales MB, Puig N, Maiso P, Rodriguez I, et al. Phenotypic and genomic analysis of multiple myeloma minimal residual disease tumor cells: A new model to understand chemoresistance. Blood. 2016;127(15):1896-1906.

59. Maurer LM, Ma W, Mosher DF. Dynamic structure of plasma fibronectin. Crit Rev Biochem Mol Biol. 2016 Jul 3;51(4):213-227.

60. Sharma A. Crystal structure of a heparin-and integrin-binding segment of human fibronectin. EMBO J. 1999 Mar 15;18(6):1468-1479.

61. Sanz-Rodríguez F, Ruiz-Velasco N, Pascual-Salcedo D, Teixidó J. Characterization of VLA-4dependent myeloma cell adhesion to fibronectin and VCAM-1. Br J Haematol. 1999;107(4):825834.

62. Hazlehurst LA, Damiano JS, Buyuksal I, Pledger WJ, Dalton WS. Adhesion to fibronectin via $\beta 1$ integrins regulates $\mathrm{p} 27 \mathrm{kip} 1$ levels and contributes to cell adhesion mediated drug resistance (CAMDR). Oncogene. 2000 Sep 7;19(38):4319-4327.

63. Volpi N, Schiller J, Stern R, Soltes L. Role, Metabolism, Chemical Modifications and Applications of Hyaluronan. Curr Med Chem. 2009;16(14):1718-1745.

64. Vincent T, Molina L, Espert L, Mechti N. Hyaluronan, a major non-protein glycosaminoglycan component of the extracellular matrix in human bone marrow, mediates dexamethasone resistance in multiple myeloma. Br J Haematol. 2003 Apr;121(2):259-269.

65. Vincent T, Jourdan M, Sy M-S, Klein B, Mechti N. Hyaluronic Acid Induces Survival and Proliferation of Human Myeloma Cells through an Interleukin-6-mediated Pathway Involving the Phosphorylation of Retinoblastoma Protein. J Biol Chem. 2001 May 4;276(18):14728-14736.

66. Bjorklund CC, Baladandayuthapani V, Lin HY, Jones RJ, Kuiatse I, Wang H, et al. Evidence of a role for CD44 and cell adhesion in mediating resistance to lenalidomide in multiple myeloma: Therapeutic implications. Leukemia. 2014;28(2):373-383.

67. Reijmers RM, Spaargaren M, Pals ST. Heparan sulfate proteoglycans in the control of B cell development and the pathogenesis of multiple myeloma. FEBS J. 2013;280(10):2180-2193.

68. Meneghetti MCZ, Hughes AJ, Rudd TR, Nader HB, Powell AK, Yates EA, et al. Heparan sulfate and heparin interactions with proteins. J R Soc Interface. 2015 Sep 6;12(110):20150589.

69. Sanderson RD, Yang Y. Syndecan-1: a dynamic regulator of the myeloma microenvironment. Clin Exp Metastasis. 2008 Apr 20;25(2):149-159.

70. Anderson KC, Kyle RA, Dalton WS, Landowski T, Shain K, Jove R, et al. Multiple Myeloma: New Insights and Therapeutic Approaches. Hematology. 2000 Jan 1;2000(1):147-165. 
71. Gauba V, Hartgerink JD. Self-Assembled Heterotrimeric Collagen Triple Helices Directed through Electrostatic Interactions. J Am Chem Soc. 2007 Mar;129(9):2683-2690.

72. Ridley R, Xiao H, Hata H, Woodliff J, Epstein J, Sanderson R. Expression of syndecan regulates human myeloma plasma cell adhesion to type I collagen. Blood. 1993 Feb 1;81(3):767-774.

73. Sukhdeo K, Mani M, Zhang Y, Dutta J, Yasui H, Rooney MD, et al. Targeting the $\beta$-catenin/TCF transcriptional complex in the treatment of multiple myeloma. Proc Natl Acad Sci. 2007 May $1 ; 104(18): 7516-7521$.

74. Ren Z, van Andel H, de Lau W, Hartholt RB, Maurice MM, Clevers H, et al. Syndecan-1 promotes Wnt/ $\beta$-catenin signaling in multiple myeloma by presenting Wnts and R-spondins. Blood. 2018 Mar 1;131(9):982-994.

75. Edmondson R, Broglie JJ, Adcock AF, Yang L. Three-dimensional cell culture systems and their applications in drug discovery and cell-based biosensors. Assay Drug Dev Technol. 2014;12(4):207-218.

76. Pampaloni F, Reynaud EG, Stelzer EHK. The third dimension bridges the gap between cell culture and live tissue. Nat Rev Mol Cell Biol. 2007 Oct;8(10):839-845.

77. Belloni D, Heltai S, Ponzoni M, Villa A, Vergani B, Pecciarini L, et al. Modeling multiple myeloma-bone marrow interactions and response to drugs in a $3 \mathrm{~d}$ surrogate microenvironment. Haematologica. 2018;103(4):707-716.

78. Chaicharoenaudomrung N, Kunhorm P, Noisa P. Three-dimensional cell culture systems as an in vitro platform for cancer and stem cell modeling. World J Stem Cells. 2019 Dec 26;11(12):10651083.

79. Huang L, Abdalla AME, Xiao L, Yang G. Biopolymer-Based Microcarriers for Three-Dimensional Cell Culture and Engineered Tissue Formation. Int J Mol Sci. 2020 Mar 10;21(5):1895.

80. Humpel C. Organotypic brain slice cultures: A review. Neuroscience. 2015 Oct;305:86-98.

81. Mehta G, Hsiao AY, Ingram M, Luker GD, Takayama S. Opportunities and challenges for use of tumor spheroids as models to test drug delivery and efficacy. J Control Release. 2012 Dec;164(2):192-204.

82. Khaitan D, Chandna S, Arya MB, Dwarakanath BS. Establishment and characterization of multicellular spheroids from a human glioma cell line; implications for tumor therapy. J Transl Med. 2006;4:1-13.

83. Drury JL, Mooney DJ. Hydrogels for tissue engineering: scaffold design variables and applications. Biomaterials. 2003 Nov;24(24):4337-4351.

84. Farrukh S, Mustafa K, Hussain A, Ayoub M. Synthesis and Applications of Carbohydrate-Based Hydrogels. In 2018. p. 1-24.

85. Emmerichs N, Wingender J, Flemming H-C, Mayer C. Interaction between alginates and manganese cations: identification of preferred cation binding sites. Int J Biol Macromol. 2004 Apr;34(1-2):73-79.

86. Arnal-Pastor M, Comín-Cebrián S, Martínez-Ramos C, Monleón Pradas M, Vallés-Lluch A. Hydrophilic surface modification of acrylate-based biomaterials. J Biomater Appl. 2016 Apr 13;30(9):1429-1441.

87. Serrano-Aroca Á, Deb S. Acrylic-Based Materials for Biomedical and Bioengineering Applications. In: Acrylate Polymers for Advanced Applications. IntechOpen; 2020.

88. Alfred R, Radford J, Fan J, Boon K, Krawetz R, Rancourt D, et al. Efficient suspension bioreactor expansion of murine embryonic stem cells on microcarriers in serum-free medium. Biotechnol Prog. 2011 May;27(3):811-823.

89. Derakhti S, Safiabadi-Tali SH, Amoabediny G, Sheikhpour M. Attachment and detachment strategies in microcarrier-based cell culture technology: A comprehensive review. Mater Sci Eng C. 2019 Oct; 103:109782.

90. Sart S, Agathos SN, Li Y. Engineering stem cell fate with biochemical and biomechanical properties of microcarriers. Biotechnol Prog. 2013 Nov;29(6):1354-1366.

91. Privalova A, Markvicheva E, Sevrin C, Drozdova M, Kottgen C, Gilbert B, et al. Biodegradable polyester-based microcarriers with modified surface tailored for tissue engineering. J Biomed Mater Res Part A. 2015 Mar;103(3):939-948.

92. Jakubikova J, Cholujova D, Hideshima T, Gronesova P, Soltysova A, Harada T, et al. A novel 3D mesenchymal stem cell model of the multiple myeloma bone marrow niche: biologic and clinical applications. Oncotarget. 2016 Nov 22;7(47):77326-77341.

93. Kirshner J, Thulien KJ, Martin LD, Marun CD, Reiman T, Belch AR, et al. A unique threedimensional model for evaluating the impact of therapy on multiple myeloma. Blood. 2008;112(7):2935-2945.

94. de la Puente P, Muz B, Gilson RC, Azab F, Luderer M, King J, et al. 3D tissue-engineered bone 
marrow as a novel model to study pathophysiology and drug resistance in multiple myeloma. Biomaterials. 2015 Dec;73:70-84.

95. Ferrarini M, Steimberg N, Ponzoni M, Belloni D, Berenzi A, Girlanda S, et al. Ex-Vivo Dynamic 3-D Culture of Human Tissues in the RCCS ${ }^{\mathrm{TM}}$ Bioreactor Allows the Study of Multiple Myeloma Biology and Response to Therapy. PLoS One. 2013;8(8):1-10.

96. Mazzoleni G, Boukhechba F, Steimberg N, Boniotti J, Bouler J-M, Rochet N. Impact of Dynamic Culture in the RCCS! Bioreactor on a Three-Dimensional Model of Bone Matrix Formation. Procedia Eng. 2011;10:3662-3667.

97. Becker JL, Souza GR. Using space-based investigations to inform cancer research on Earth. Nat Rev Cancer. 2013 May 12;13(5):315-327.

98. Bae J-S, Seo E-J, Kang I-K. Synthesis and characterization of heparinized polyurethanes using plasma glow discharge. Biomaterials. 1999 Mar;20(6):529-537.

99. Clara-Trujillo S, Marín-Payá JC, Cordón L, Sempere A, Gallego Ferrer G, Gómez Ribelles JL. Biomimetic microspheres for 3D mesenchymal stem cell culture and characterization. Colloids Surfaces B Biointerfaces. 2019 May;177:68-76.

100. Zhao MY, Li LH, Li B, Zhou CR. LBL coating of type I collagen and hyaluronic acid on aminolyzed PLLA to enhance the cell-material interaction. Express Polym Lett. 2014;8(5):322-35.

101. Zeeb B, Saberi AH, Weiss J, McClements DJ. Retention and release of oil-in-water emulsions from filled hydrogel beads composed of calcium alginate: impact of emulsifier type and $\mathrm{pH}$. Soft Matter. 2015;11(11):2228-2236.

102. Khan KA, Farooq R, Iqbal MN. Chemical effects of UV radiation on aqueous solutions of heparinCa salt. Polym Photochem. 1985 Jan;6(6):465-474.

103. Jariashvili K, Madhan B, Brodsky B, Kuchava A, Namicheishvili L, Metreveli N. Uv damage of collagen: Insights from model collagen peptides. Biopolymers. 2012 Mar;97(3):189-198.

104. Rieger AM, Nelson KL, Konowalchuk JD, Barreda DR. Modified Annexin V/Propidium Iodide Apoptosis Assay For Accurate Assessment of Cell Death. J Vis Exp. 2011 Apr 24;(50).

105. Tabchi S, Nair R, Kunacheewa C, Patel KK, Lee HC, Thomas SK, et al. Retrospective Review of the Use of High-Dose Cyclophosphamide, Bortezomib, Doxorubicin, and Dexamethasone for the Treatment of Multiple Myeloma and Plasma Cell Leukemia. Clin Lymphoma Myeloma Leuk. 2019 Sep;19(9):560-569.

106. Márk Á, Varga G, Timár B, Kriston C, Szabó O, Deák L, et al. The effect of microenvironmental factors on the development of myeloma cells. Hematol Oncol. 2017 Dec;35(4):741-745.

107. Wang J, De Veirman K, De Beule N, Maes K, De Bruyne E, Van Valckenborgh E, et al. The bone marrow microenvironment enhances multiple myeloma progression by exosome-mediated activation of myeloid-derived suppressor cells. Oncotarget. 2015 Dec 22;6(41):43992-44004.

108. Robak P, Drozdz I, Szemraj J, Robak T. Drug resistance in multiple myeloma. Cancer Treat Rev. 2018 Nov;70(September):199-208.

109. Hou J, Wei R, Qian J, Wang R, Fan Z, Gu C, et al. The impact of the bone marrow microenvironment on multiple myeloma (Review). Oncol Rep. 2019;42(4):1272-1282.

110. Meads MB, Hazlehurst LA, Dalton WS. The bone marrow microenvironment as a tumor sanctuary and contributor to drug resistance. Clin Cancer Res. 2008;14(9):2519-2526.

111. Ribatti D. The discovery of plasma cells: An historical note. Immunol Lett. 2017 Aug;188:64-7.

112. Salmerón-Sánchez M, Rico P, Moratal D, Lee TT, Schwarzbauer JE, García AJ. Role of materialdriven fibronectin fibrillogenesis in cell differentiation. Biomaterials. 2011;32(8):2099-2105.

113. Campillo-Fernández AJ, Unger RE, Peters K, Halstenberg S, Santos M, Salmerón Sánchez M, et al. Analysis of the biological response of endothelial and fibroblast cells cultured on synthetic scaffolds with various hydrophilic/hydrophobic ratios: Influence of fibronectin adsorption and conformation. Tissue Eng - Part A. 2009;15(6):1331-1341.

114. Ribeiro C, Panadero JA, Sencadas V, Lanceros-Méndez S, Tamaño MN, Moratal D, et al. Fibronectin adsorption and cell response on electroactive poly(vinylidene fluoride) films. Biomed Mater. 2012 Jun 1;7(3):035004.

115. Chen Q, Yu H, Wang L, Abdin Z, Yang X, Wang J, et al. Synthesis and characterization of amylose grafted poly(acrylic acid) and its application in ammonia adsorption. Carbohydr Polym. 2016 Nov; 153:429-434.

116. Silvia Flores Sánchez. Micropartículas de polímeros acrílicos funcionalizados con heparina para el cultivo celular en entornos 3D. Universitat de València 2016 (Unpublished data).

117. Yaghmur A, Ghazal A, Ghazal R, Dimaki M, Svendsen WE. A hydrodynamic flow focusing microfluidic device for the continuous production of hexosomes based on docosahexaenoic acid monoglyceride. Phys Chem Chem Phys. 2019;21(24):13005-13013.

118. Götz A, Nikzad-Langerodi R, Staedler Y, Bellaire A, Saukel J. Apparent penetration depth in 
attenuated total reflection Fourier-transform infrared (ATR-FTIR) spectroscopy of Allium cepa L. epidermis and cuticle. Spectrochim Acta Part A Mol Biomol Spectrosc. 2020 Jan;224:117460.

119. van Hoogmoed CG, Busscher HJ, de Vos P. Fourier transform infrared spectroscopy studies of alginate-PLL capsules with varying compositions. J Biomed Mater Res. 2003 Oct 1;67A(1):172178.

120. Mahapatra C, Jin GZ, Kim HW. Alginate-hyaluronic acid-collagen composite hydrogel favorable for the culture of chondrocytes and their phenotype maintenance. Tissue Eng Regen Med. 2016;13(5):538-546.

121. Júnior ZSS, Botta SB, Ana PA, França CM, Fernandes KPS, Mesquita-Ferrari RA, et al. Effect of papain-based gel on type I collagen - spectroscopy applied for microstructural analysis. Sci Rep. 2015 Sep 23;5(1):11448.

122. Susi H, Ard JS, Carroll RJ. The infrared spectrum and water binding of collagen as a function of relative humidity. Biopolymers. 1971;10(9):1597-1604.

123. de Oliveira SA, da Silva BC, Riegel-Vidotti IC, Urbano A, de Sousa Faria-Tischer PC, Tischer CA. Production and characterization of bacterial cellulose membranes with hyaluronic acid from chicken comb. Int J Biol Macromol. 2017 Apr;97:642-653.

124. Yang Y, Zhao Y, Lan J, Kang Y, Zhang T, Ding Y, et al. Reduction-sensitive CD44 receptortargeted hyaluronic acid derivative micelles for doxorubicin delivery. Int J Nanomedicine. 2018 Jul;Volume 13:4361-4378.

125. Soh KT, Tario JD, Wallace PK. Diagnosis of Plasma Cell Dyscrasias and Monitoring of Minimal Residual Disease by Multiparametric Flow Cytometry. Clin Lab Med. 2017 Dec;37(4):821-53.

126. Shen Y, Vignali P, Wang R. Rapid Profiling Cell Cycle by Flow Cytometry Using Concurrent Staining of DNA and Mitotic Markers. BIO-PROTOCOL. 2017;7(16).

127. Landberg G, Tan EM, Roos G. Flow cytometric multiparameter analysis of proliferating cell nuclear antigen/cyclin and Ki-67 antigen: A new view of the cell cycle. Exp Cell Res. 1990 Mar;187(1):111-118.

128. Davies D, Allen P. DNA Analysis by Flow Cytometry. In: Flow Cytometry. Totowa, NJ: Humana Press; 2007. p. 165-179.

129. Eudey TL. Statistical considerations in DNA flow cytometry. Stat Sci. 1996 Nov;11(4):320-334.

130. Audo R, Hua C, Hahne M, Combe B, Morel J, Daien CI. Phosphatidylserine Outer Layer Translocation Is Implicated in IL-10 Secretion by Human Regulatory B Cells. van Zelm MC, editor. PLoS One. 2017 Jan 10;12(1):e0169755.

131. Lecoeur H, Ledru E, Prévost M-C, Gougeon M-L. Strategies for phenotyping apoptotic peripheral human lymphocytes comparing ISNT, annexin-V and 7-AAD cytofluorometric staining methods. J Immunol Methods. 1997 Dec;209(2):111-123.

132. Sharfstein ST, Kaisermayer C. Microcarrier Culture. In: Encyclopedia of Industrial Biotechnology. Hoboken, NJ, USA: John Wiley \& Sons, Inc.; 2010.

133. Bazzoni G, Ma L, Blue M-L, Hemler ME. Divalent Cations and Ligands Induce Conformational Changes That Are Highly Divergent among $\beta 1$ Integrins. J Biol Chem. 1998 Mar 20;273(12):6670-6678.

134. Masumoto A, Hemler ME. Multiple activation states of VLA-4. Mechanistic differences between adhesion to CS1/fibronectin and to vascular cell adhesion molecule-1. J Biol Chem. 1993 Jan 5;268(1):228-234.

135. Martínez-Viñambres E, García-Trujillo JA, Rodríguez-Martín E, Villar LM, Coll J, Roldán E. CD29 expressed on plasma cells is activated by divalent cations and soluble CD106 contained in the bone marrow plasma: refractory activation is associated with enhanced proliferation and exit of clonal plasma cells to circulation in multiple myeloma patie. Leukemia. 2012 May 2;26(5):10981105.

136. Leone M, Romeijn S, Slütter B, O’Mahony C, Kersten G, Bouwstra JA. Hyaluronan molecular weight: Effects on dissolution time of dissolving microneedles in the skin and on immunogenicity of antigen. Eur J Pharm Sci. 2020 Apr 15;146:105269

137. Ritchie JP, Ramani VC, Ren Y, Naggi A, Torri G, Casu B, et al. SST0001, a Chemically Modified Heparin, Inhibits Myeloma Growth and Angiogenesis via Disruption of the Heparanase/Syndecan1 Axis. Clin Cancer Res. 2011 Mar 15;17(6):1382-1393.

138. Koh B, Sulaiman N, Fauzi MB, Law JX, Ng MH, Idrus RBH, et al. Three dimensional microcarrier system in mesenchymal stem cell culture: a systematic review. Cell Biosci. 2020 Dec 3;10(1):75.

139. Nelson CM, Chen CS. Cell-cell signaling by direct contact increases cell proliferation via a PI3Kdependent signal. FEBS Lett. 2002 Mar 13;514(2-3):238-242.

140. San Miguel JF, Weisel KC, Song KW, Delforge M, Karlin L, Goldschmidt H, et al. Impact of prior treatment and depth of response on survival in MM-003, a randomized phase 3 study comparing 
pomalidomide plus low-dose dexamethasone versus high-dose dexamethasone in relapsed/refractory multiple myeloma. Haematologica. 2015 Oct 1;100(10):1334-1339.

141. Cao Y, Qiu GQ, Wu HQ, Wang ZL, Lin Y, Wu W, et al. Decitabine enhances bortezomib treatment in RPMI 8226 multiple myeloma cells. Mol Med Rep. 2016;14(4):3469-3475.

142. Caligaris-Cappio F, Bergui L, Gregoretti M, Gaidano G, Gaboli M, Schena M, et al. 'Role of bone marrow stromal cells in the growth of human multiple myeloma. Blood. 1991 Jun 15;77(12):26882693.

143. Rajkumar SV, Jacobus S, Callander NS, Fonseca R, Vesole DH, Williams ME, et al. Lenalidomide plus high-dose dexamethasone versus lenalidomide plus low-dose dexamethasone as initial therapy for newly diagnosed multiple myeloma: an open-label randomised controlled trial. Lancet Oncol. 2010 Jan;11(1):29-37.

144. Bam R, Khan S, Ling W, Randal SS, Li X, Barlogie B, et al. Primary myeloma interaction and growth in coculture with healthy donor hematopoietic bone marrow. BMC Cancer. 2015;15(1):114.

145. Du Q, Geller DA. Cross-Regulation Between Wnt and NF- $\kappa$ B Signaling Pathways. For Immunopathol Dis Therap. 2010;1(3):155-181. 